Historic, Archive Document

Do not assume content reflects current scientific knowledge, policies, or practices. 

1922U.S. DEPARTMENT OF AGRICULTURE, RESARVA FOREST SERVICE. HENRY S. GRAVES, Forester.

\section{INSTRUCTIONS FOR APPRAISING STUMPAGE ON NATIONAL FORESTS.}

WASHINGTON:

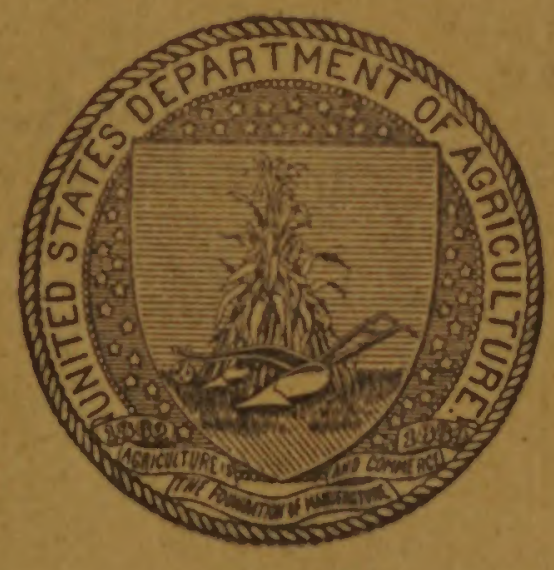

GOVERNMENT PRINTING OFFICE.

1914.

MAR $8 \quad 1946$ 


\section{UNITED STATES DEPARTMENT OF AGRICULTURE LIBRARY}

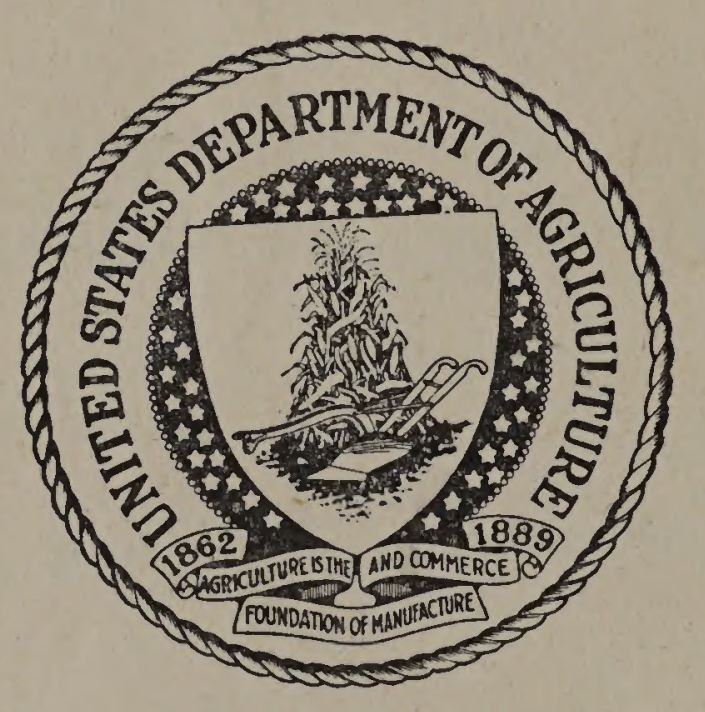

BOOK NUMBER I

$$
\begin{aligned}
& \text { Frys } \\
& \text { Reserve } \\
& 18233_{\text {9 } 8-7671}
\end{aligned}
$$

581823 
Issued November 12, 1914.

U. S. DEPARTMENT OF AGRICULTURE, FOREST SERVICE. HENRY S. GRAVES, Forester.

\section{INSTRUCTIONS FOR APPRAISING STUMPAGE ON NATIONAL FORESTS.}

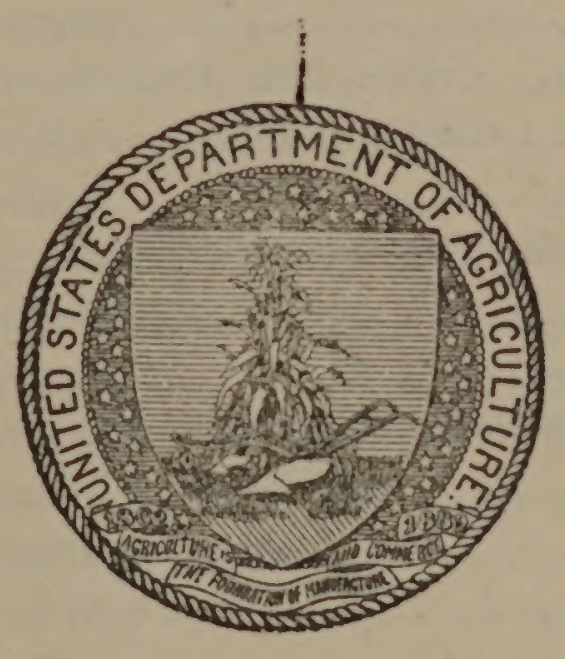

WASHINGTON:

GOVERNMENT PRINTING OFFICE.

1914. 



\section{CONTENTS.}

Purpose and use of instructions......................................

Standard terms............................................ 7

Fixed investment.......................................

Depreciation .......................................... 7

Residual and wrecking values.............................. 8

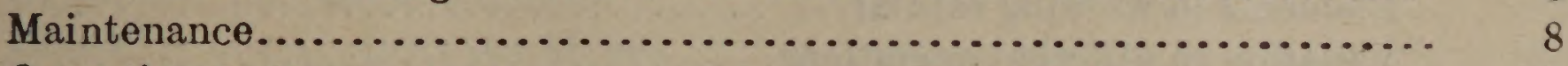

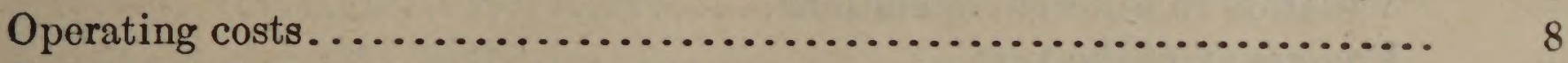

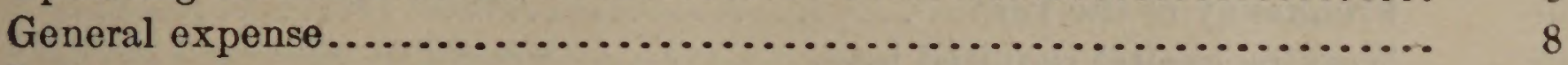

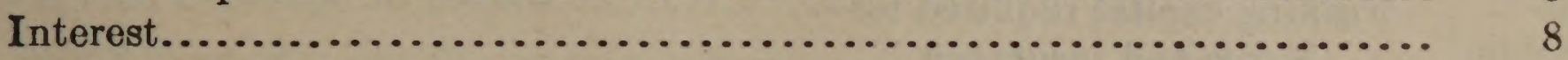

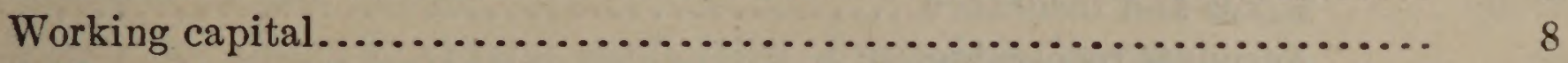

Selling price.......................................... 9

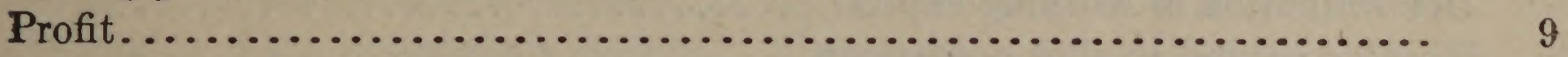

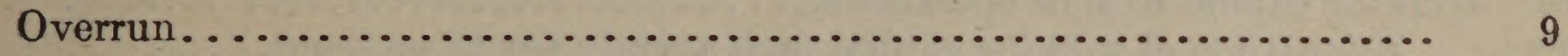

Overturn, or cost of production............................ 9

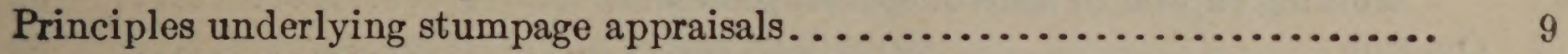

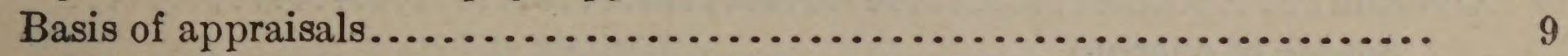

Requirements of law.................................... 9

Minimum stumpage rates. . . . . . . . . 9

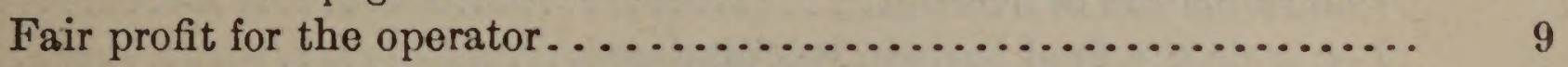

Intensive study of investments and costs..................... 10

Grouping and standardizing operating costs................. 10

Conservative calculations............................... 10

Description of logging conditions and methods................ 11

Use of appraiser's judgment............................ 11

Analysis of a proposed operation............................. 11-13

Fixed investment, depreciation, and residual or wrecking value........ 13

Inclusion of all necessary investments.................... 13

Commissaries and boarding houses....................... 13

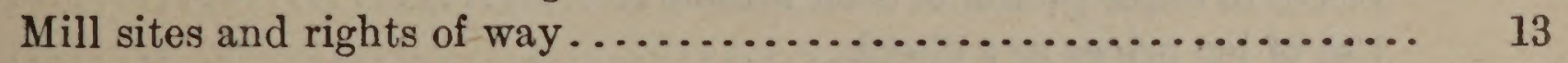

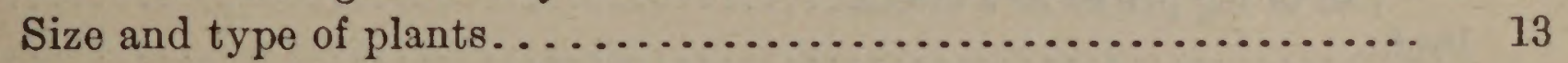

Borrowed and unborrowed capital......................... 14

Classification of investments............................ 14

Depreciation of fixed investments...................... 15

Determination of residual or wrecking value................ 16

Amounts of timber upon which investments should be depreciated and inclusion of private timber....................... 17

Valuation of existing improvements......................... 18

Determination of average investment..................... 18

Use of average manufacturing costs and depreciation........... 18

Profit bearing period of investments...................... 18

Interest charges on preliminary investments................ 18

Calculation of annual depreciation and average investment........ 19

By separate years................................. 19

By separate investment items...................... 21 
Principles underlying stumpage appraisals-Continued.

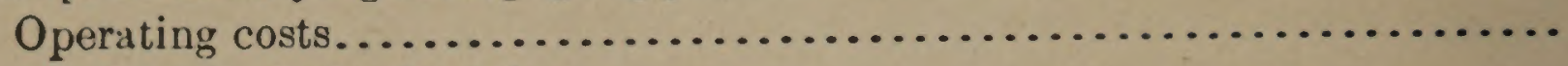

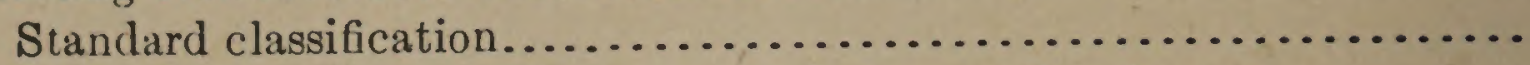

Need for ascertaining all costs; use of conservative figures..........

Checks from jobbing rates and going operations...................

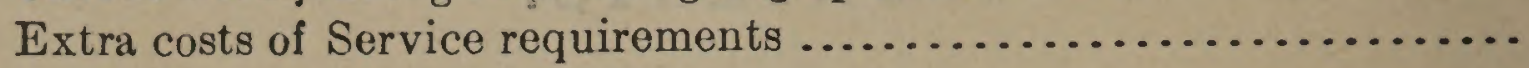

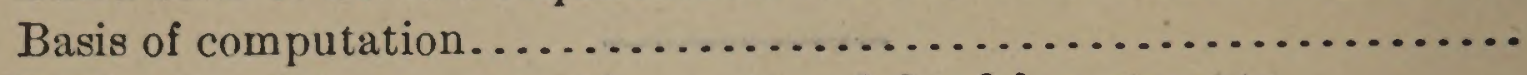

Distinction between operating costs and fixed investments.........

Maintenance.............................................

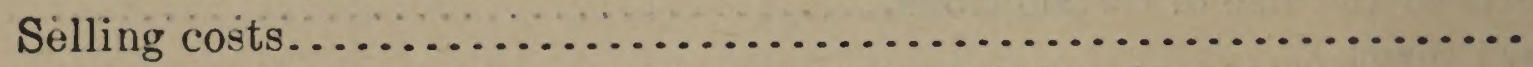

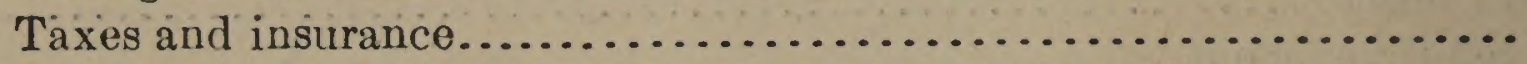

General expense.........................................

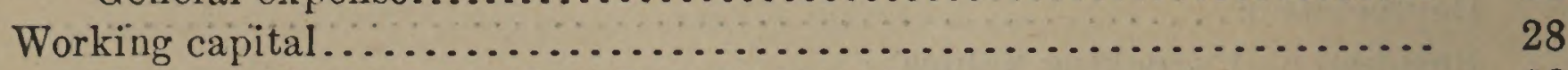

Elenients in working capital............................ 28

Variation in different operations. ....................... 29

Frequency of the turn. ............................. 29

Working capital required for-

Taxes and insurance................................. 29

Accounts receivable............................... 29

Determination of working capital........................... 29

Working capital in slow operations........................... 30

Cálculation of working capital from average stocks on hand....... 31

Working capital in sales of special products.................. 31

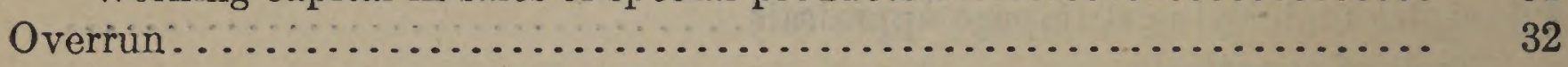

Source of overrun.................................. 32

A nècessary factor in stumpage appraisals.................. 32

Determination of overrun . . . . . . . . . . . . . . . . . . . . . . . . 32

Log scale the final basis in calculations...................... 33

Lumber and $\log$ selling prices.............................. 33

Appraisals based upon lumber selling prices................. 33

A verage selling price of various grades...................... 33

Average selling price of mixed stands..................... 34

Lumber prices prevailing in producing regions................ 34

Lumber prices during normal market conditions............... 34

State of manufacture and shipment...................... 34

Value of by-products.................................. 35

Prices of other products than lumber....................... 35

Use of $\log$ prices as a check.............................. 35

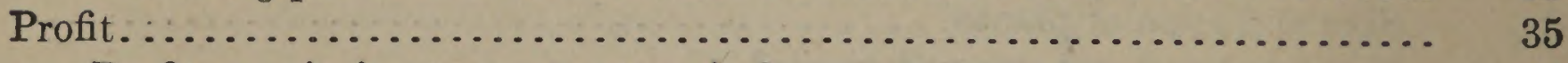

Profit margin in stumpage appraisals...................... 35

Elements in profit.................................. 36

Interest on investment.............................. 36

Reward for personal effort....................... 36

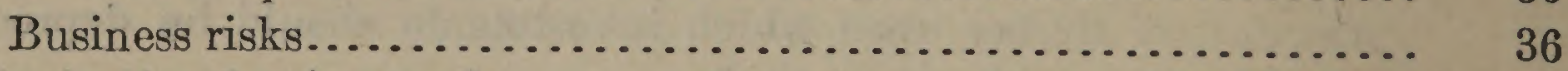

Methods of reckoning profit............................... $3^{8}$

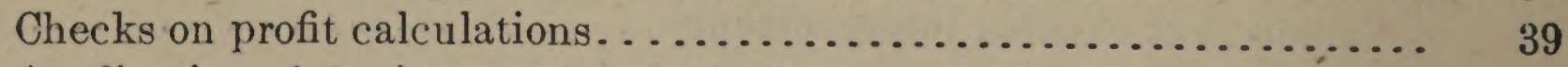

Application of the investment method.................. 40

Application of return for personal services................... 42

Application of the overturn method....................... 42

Distribution of profit and depreciation in mixed stands................ 44

Prorated on quantity of timber........................ 44

Prorated on net value of timber.............................. 44

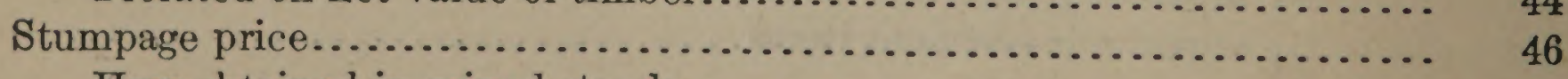

How obtained in mixed stands.......................... 46

Flat rates not desirable.................................... 46 
Principles underlying stumpage appraisals-Continued.

Stumpage price-Continued.

Use of minimum stumpage Page.

Distribution of

Distribution of loss on inferior species...................... 46

Trade valuation of inferior species..................... 46

Stumpage prices for special products.................... 47

Appraisals for small sales............................... 47

Small operations irregular.......................... 47

Appraisals based on methods in use and prices actually obtained.... 47

Liberal profits required............................ 47

Small operations competing in general markets................ 47

Schedules of prices for small sales....................... 48

Safeguards and checks........................................ 48

Check by appraiser's judgment. ........................... 48

Check by money profit per M feet......................... 48

Prices bid in former sales.................................. 48

Current stumpage appraisals............................... 48

Prices of private timber.............................. $48-49$

Methods of appraising stumpage; application of principles adopted......... $\quad 49$

Symbols for elements in appraisal.......................... 49

Examples of the investment method ....................... 49

A small operation in the Rocky Mountains................ 49

A middle-sized operation in the Blue Mountains............... 52

A large operation in the Idaho Panhandle................. 55

Examples of the overturn method............................ 62

Small shortleaf-pine operations in Arkansas.................... 62

A logger's sale in northern Montana........................ 63

A sale of tie and mining timber in Wyoming................. 65

Appendix-Form for summarizing the essential data in a stumpage appraisal... $\quad 70$ 



\section{INSTRUCTIONS FOR APPRAISING STUMPAGE ON NATIONAL FORESTS.}

Purpose of Instructions.

\section{INTRODUCTION.}

These instructions are meant to standardize the principles and methods followed in stumpage appraisals upon National Forests. They bring together the results of the experience and study of many Forest officers, but are not final, and will be revised from time to time as further experience is gained. They should, however, be applied in all appraisals, both (1) to secure uniform practice throughout the Forest Service and (2) to develop this phase of sales work by joint use and study of the same methods. One of the methods indicated will therefore be used in every stumpage appraisal. Other methods may be used, as desired by the appraising officer, and the results reported as a check upon the standard methods. Suggestions for modifications or additions to these instructions should be submitted to the Forester.

\section{Use of Instructions.}

These instructions supplement the Timber Sales Manual. They will govern the appraisal of stumpage in timber sale, timber settlement, timber trespass, and free use business, and in land exchange projects. They are for the exclusive use of Forest officers and will not be furnished to persons outside of the Forest Service.

\section{STANDARD TERMS.}

For uniformity in appraisal reports and discussions the following terms will be used with the meanings here given:

\section{Fixed Investment.}

Fixed investment, as applied to lumbering operations, is the money expended in constructing or acquiring the operating plant. It comprises not merely buildings, railroads, and woods improvements, but machinery and equipment, such as cars and locomotives, donkey engines, and teams. It includes the replacement of worn-out structures or equipment which must be renewed during an operation. Fixed investment, as distinct from working capital, is the outlay for land, structures, and equipment, which can be recovered only in a considerable period of time as portions of the cost of the plant are returned from the business and charged off in its accounts.

An initicl fixed investment is the expenditure for these purposes required at the beginning of an operation, to start production at the normal capacity of the plant. A subsequent fixed investment is any later outlay for the extensiou or renewal of improvements or equipment.

\section{Depreciation.}

Shrinkage in the value of fixed investment is called depreciation. At the end of an operation the buildings, transportation improvements, and equipment are valueless or worth but a portion of their first cost. Depreciation is this decrease in the value of fixed investments which must, in one form or another, be restored to the original capital from the proceeds of the business. 


\section{ResIdual and Wrecking Values.}

Fixed investments may have some value at the end of an operation. If this value exists because of opportunity for continued use in place, as where additional blocks of timber are availahle to a partly used nill, it is known as residual value. If the value is only for removal and use elsewhere, or for sale as scrap, it is known as urecking value.

Residual or wrecking value is equivalent to first cost less depreciation. As the amount of depreciation is decreased, residual value approaches the original investment and may nearly equal it in the case of railroads and other permanent structures. Investments in the lumber business, however, are seldom maintained at a constant capital value, as is frequently the case in industries of a more permanent character.

Maintenance.

Maintenance includes all charges for the upkeep and repair of fixed investments. It is an operating cost, consisting of labor, materials, and new parts of equipment used in repairs. Unlike depreciation, maintenance bears no relation to the cost of fixed investments. It is a current charge, like felling or skidding, for keeping buildings, structures, machinery, and tools in condition for doing the work for which they were designed. Any expenditure which serves simply to keep a structure or piece of equipment up to its original and intended capacity will be regarded as maintenance.

No arbitrary line need be drawn between maintenance and fixed iuvestment in the matter of replaceinents. The replacement of complete units like locomotives or donkey engines is ordinarily regarded as a subsequent fixed investment. The replacement of mill machinery is usually charged as maintenance. The replacement of shortlived equipment, such as steel cable, is ordinarily carried as a current operating cost. Iocal trade practice should guide the treatment of such items in National Forest appraisals.

\section{Operating Costs.}

Operating costs consist of all expenditures in an operation except for stumpage and fixed investments. They are the current charges for labor, supplies, and other expenditures required in logging and manufacturing, from stump to car. They include maintenance, taxes, insurance, and general expense.

\section{General Expense.}

General expense is a convenient term to designate the operating costs which are not related to any distinct and recognized step in logging or manufacture. It includes supervision of the operation as a whole, office expenses, selling costs, and such miscellaneous items as cruising and fire protection. It does not include taxes and insurance, which are sufficiently specific to be treated separately.

The term overhead charges is frequently used in the trade to designate expenditures of this character. General expense is preferred as a more applicable term.

\section{Interest.}

As used in Forest Service appraisals, interest is neither one of the regular costs nor a part of the returns from the business. Interest on invested capital at any fixed rate will not be included in the cost of production, and all returns will be shown in one place as profit. The term will be used only to mean interest on money invested in improvements during the period before cutting begins, which will be made part of the fixed investment as computed on the date when logging commences.

\section{Working Capital.}

Working capital is the money which must be available to pay for stumpage, labor, supplies, insurance, and other current expenditures in the operation. It includes most of the operating costs, but excludes any sums expended for fixed investments. Working capital can usually be regarded as a constant fund drawn upon from time to time for operating costs and replaced by a portion of the receipts. 


\section{Selling Price.}

Selling price is the average mill-run value of the product of an operation per thousand board feet or other unit. In lumber production it is the average invoice price of the various grades manufactured f. 0 . b. cars at the mill or nearest common-carrier shipping point. With other products, it is the average price of all grades and sizes at the point, usually represented by common-carrier shipment, where the specific operation dealt with in the appraisal terminates. Selling price should ordinarily be taken as the average price at which the product is billed less actual freight, or scheduled freights with underweights adjusted.

The average selling price of a species or a tract of timber is the average price of all grades and sizes of the manufactured product. This product may include a considerable variety of form and finish. As a standard practice, factory products and the higher forms of finish will not be included unless necessary to arrive at a satisfactory valuation.

Profit.

Profit is the money returned from sales of the product over and above depreciation of fixed investments, operating costs, and payments for stumpage. Profit must be distinguished from a margin for profit. The latter is the profit element used in Service appraisals. Aside from the actual profit estimated as due the operator, it includes a surplus to cover unforeseen losses and risks. The margin for profit may be calculated as a percentage return on the money invested, a given amount per unit manufactured, or a percentage of the total unit cost of production.

\section{Overrun.}

Overrun is the difference between log scale and lumber tally at date of sale, on the same quantity of material in the log. It results from the inaccuracies of log scales, and particularly the use of thinner saws since the prevailing scale rules were devised, from closer utilization of short lengths and narrow widths, from cutting dimension stock instead of inch boards, and other features of manufacture. Overrun is computed as a percentage increase on the log scale, an overrun of 10 per cent meaning that 1,000 feet $\log$ scale will cut 1,100 feet of lumber.

\section{Overturn or Cost of Production.}

The overturn is the total production cost of each thousand board feet log scale or other unit. It includes depreciation and all operating costs. Overturn plus profit and stumpage price equals the selling price of the manufactured product.

\section{PRINCIPLES UNDERLYING STUMPAGE APPRAISALS.}

\section{BASIS OF APPRAISALS.}

\section{Market Value Required by Law.}

The act of June 4, 1897, provides that National Forest timber may be sold at "not less than the appraised value." In applying this requirement, the aim of stumpage appraisals will be to ascertain the existing market value of the timber.

\section{Minimum Stumpage Rates.}

Minimum rates for each species are established by the Forester for every Forest area which has the same general market and manufacturing conditions. They constitute upset prices for use in all stumpage appraisals.

\section{Fair Profit for Operator.}

Subject to the minimum rates, National Forest stumpage will be regarded as worth the selling value of its product less all costs of producing it and a fair margin for profit to the operator. Appraisals should not offer large speculative profits. Operators on - National Forests must be willing to cut and manufacture stumpage for a fair return, 
representing compensation for time and ability and an industrial rate on the capital required, which is protected by a reasonable margin against unforeseen losses. Profit is not guaranteed by the Forest Service; but the basis of all appraisals is a margin between cost and selling price under normal industrial conditions which will satisfy a prudent operator, his business situation and the advantages of buying Government stumpage being considered.

It must not be overlooked that this margin is not a clear or even a probable return to the operator. A portion of it covers the risks incident to practically every lumbering operation. These are the possible and unforeseen losses which can not be provided for in the appraisal, including the large element of chance in the lumber market. But a part of the estimated margin will normally be netted to the purchaser as actual prufit. (See p. 41 for a discussion of rates of profit.)

Intensive Study of Investments and Costs.

National Forest stumpage must not be appraised by adopting current local prices, by uniform rates on the same Forest, or by guess work or hasty assumptions. Appraisals should, on the contrary, be based upon intensive study of investments, costs, and profits in each specific case. Each chance presents a problem in itself. All of its elements must be worked out as fully as practicable, in accordance with the appraiser's judgment of the most logical and efficient means of exploitation.

Every necessary outlay of money should be caught up as far as possible and given proper weight. It is important not to overlook the less obvious investments or costs, such as interest on preliminary improvements, superintendence, and the cost of employing and insuring labor. Equally thorough consideration should be given to all sources of income. It must not be assumed that certain costs will be offset approximately by certain indefinite returns and hence that both can be eliminated from the calculation. The effort of the appraiser should be to work out accurately all expenditures and returns in the specific case before him.

Exceptions to this rule will be permitted only in the case of small sales on parts of Forests having substantially the same conditions, for which schedules of stumpage prices have been established by supervisors under authority from the District Forester. (See "Appraisals for small sales," p. 47.)

Grouping and Standardizing Operating Costs.

An analysis of the operating costs on each chance is essential in appraising its stumpage. As data on more operations and chances in the region are obtained and compared, however, it may become possible to standardize cost items or groups of items at figures gencrally applicable to gaing conditions in the industry, or to local types of logging or milling. These standards should be conservative, particularly with regard to fluctuations in operating costs from year to year on the same job. When accurately obtained, standard costs for specific items, like maintenance of logging equipment, or complete steps, like logging to rail or manufacturing, may be used if study of the chance indicates that they are applicable. Manufacturing costs for mills of each type and capacity are especially adapted to standardization. In any event standard costs form an excellent check on the calculation.

Calculations Must be Conservative.

Calculations should be conservative, based upon average rather than maximum efficiency in the region. Logging costs ordinarily vary 10 or 15 per cent from average figures because of the varying ability of different operators who may all be gond, practical loggers. As a standard rule, costs should be based upon the work of the average operator rather than that of either the most or the least efficient. It is also important to allow for the usual fluctuation in operating costs frcm year to year on the same piece of work, by checking cost3 in going operations over several seasons. Conservative calculations are of special inportance in small sales. (See p. 47.) 


\section{Description of Logging Conditions and Methods.}

It is necessary not only that the appraiser satisfy his own judgment in fixing stumpage rates, but also that of the officer who passes upon his findings. To this end, a concise description of the controlling topographic, forest, and industrial conditions and a brief account of the methods of operation prcposed should be included in appraisal reports. This may be greatly condensed, but should include enough to explain and justify the calculations, particularly as regards the grade and value of the product and the investment required.

Use of Appraiser's Judgment.

It is the business of the appraiser to apply these instructions to the conditions on the particular chance and report the results obtained. It is fully as important, however, that he check such results by his own judgment and business sense. He should consider fully other factors which ought to be taken into account in fixing prices, such as comparison between diffezent chances or rapid deterioration of the timber. He should report definitely what in his judgment the prices should be, wholly independent of the calculation under these instructions, giving plainly the facts or considerations influencing this judgment. (For an extended discussion of this point see "Safeguards and checks," p. 48.)

The same applies to the use of other methods of appraisal which are believed to be sounder in principle or more applicable to the case in hand. First carry out the prescribed calculation to a definite conclusion. Then offset against it the results obtained by other methods with the reasons supporting them.

\section{ANALYSIS OF A PROPOSED OPERATION.}

\section{Boundaries and Cut of the Chance.}

The discussion of principles and methods will be facilitated by a bird's-eye view of the appraiser's work. After the estimate and topographic map are completed, the first steps are to determine the boundaries of the sale area, eliminating unmerchantable timber and ground on which logging is impracticable; the proportion of each species which can be cut under the methods of marking established for the chance or forest type; and the estimated cut by species and lumber grades.

In defining the boundaries of the cutting, it is necessary to approximate the amount of additional National Forest stumpage which will logically be handled by the same improvements; and also the private stumpage which is under the control of a prospective purchaser or may be obtained by him and which forms part of the same chance. These factors directly affect the layout and depreciation of fixed investments and may bear upon the timeliness and desirability of the sale.

\section{Most Important Factors.}

The factors whose careful working out is then most essential to an accurate appraisal are:

(1) The quality of the timber and value of its product.

(2) The investment required, involving a grasp of current lumbering methods and equipment and of the topographic layout and plan of operation.

(3) Operating costs.

The grade of the product, judged in the light of local milling and marketing practice, is probably the single factor of greatest importance affecting stumpage values in large sales.

\section{Layout of the Operation.}

It is first necessary to decide upon the general methods of logging which should be employed, the size and type of manufacturing plant, if one is required, and the size, annual output, and duration of the operation. The location of the main artery of log transportation, whether by railroad, drivable stream, sleigh road, or flume, then follows; 
and the projection of its principal feeders, such as logging spurs, chutes, pole and other roads, forming the complete system of log transportation. Next to judging the quality of stumpage, this grasp of the layout of logging improvements is the most important requisite of accurate valuation.

From the approximate location of landings or banking grounds on the main line of transportation or its feeders, the appraiser should block out the chance into logging units for which costs from stump to landing need to be computed separately on account of variations in the character of the ground or timber.

\section{Investments in Logging Improvements.}

The appraiser is now ready to estimate the cost of transportation improvements from landing to mill and of logging improvements from stump to landing. Working these fixed investments out, unit by unit, he should estimate the initial outlay required to put the operation under way; then the additional sums which must be expended from time to time as logging is extended in to additional blocks. He should determine approximately how long each improvement, whether a spur grade, chute, sleigh road, or splash dan, will be in use. On a railroad chance, for example, a certain mileage of steel rails, picked up and relaid on spur after spur, may meet the requirements of log transportation for a considerable period, requiring additions only as the actual mileage in use at the same time must be increased to reach the less accessible timber. This represents a stable investment continued with little change throughout the operation. On the other hand, the cost of grading a spur and laying track for logging out a single gulch may be invested for but two or three years, after which the spur is abandoned. There may thus be frequent expansions or contractions of the investment in woods improvements.

\section{Residual or Wrecking Values.}

The next requirement for the appraisal is the residual or wrecking value of each improvement at the end of its use in the sale; hence the annual rate at which the original investment must be depreciated. This leads easily to the investment on which profit is due and to the average yearly depreciation.

\section{Investments in Equipment.}

The determination of fixed investments, residual or wrecking values, and yearly depreciation must be repeated for transportation and logging equipment, such as rolling stock, donkey engines, teams, and trucks. The first cost of the various items of machinery and apparatus must be ascertained, the rate at which they are worn out, and the time when each kind of equipment must be increased or can be reduced as tho operation is extended over the entire chance.

\section{Investment in Manufacturing Plant.}

A like computation must be made of investments in land, buildings, and equipment for the manufacturing plant where one is required. This is often the most permanent part of the enterprise. Its depreciation requires an approximation of the additional timber, public or private, which is accessible and should contribute to its operating life.

\section{Determination of Operating Costs.}

The next duty of the appraiser is to estimate the cost of maintaining the various parts of the plant in working condition. This is a current operating cost, but from its nature must be considered in connection with the character and durability of each structure or class of equipment. The calculation is then ready for the remaining operating costs, chiefly labor, for logging, transportation, and manufacture. These must include any special or additional costs arising from contract requirements of the Forest Service, such as brush disposal or cutting snags. The calculation should be carried through all details of the business, however remote from the woods. General expenses for superintendence, lumber sales, clerical and other office charges, taxes on 
improvements and equipment, on logs in transit and on lumber in the yard, fire insurance on the portions of the plant and stock of lumber and logs which are normally insured by conservative operators, and liability insurance for injuries to labor are all items which must be estimated for in operations to which they apply.

Determination of Working Capital.

With the operating costs before him, the appraiser is in a position to approximate the working capital, as distinct from fixed investment, which is required to carry the business with its current charges and its periodic returns from sales of lumber. This involves particularly an estimate of the yard stock which must be carried on hand in the normal course of business, or the average length of time during which the costs put into lumber must be carried by the operator before he is reimbursed by its sale.

Lumber Selling Prices and Overrun.

Finally, the mill-run selling price of each species to be cut must be ascertained together with the value of lath, slabs, and any other by-products whose manufacture may be practicable. Mill overrun for the class of timber must also be determined and costs throughout the whole operation and all returns put in terms of log scale.

When these estimates are re duced to final terms, the appraiser will have befure him:

(1) The amount of money required for the business, in fixed improvements and equipment and in working funds.

(2) The part of this capital which must be depreciated; that is, which is not returned in tangible assets of some form at the conclusion of the sale.

(3) The operating costs, in terms of thousand board feet, log scale, from the stump to the sale of lumber.

(4) The value of the lumber and by-products manufactured from the average thoueand board feet, log scale, of each species.

\section{FIXED INVESTMENT, DEPRECIATION, AND RESIDUAL OR WRECKING VALUE.}

\section{Inclusion of All Necessary Investments.}

All investments which will actually be required in logging and manufacturing a body of National Forest stumpage should be estimated as closely as practicable in the appraisal. Items should not be omitted because of uncertainty as to the methoits of operation which will be adopted by the purchaser. All improvements and equip. ment necessary in the judgment of the appraiser for the most logical handling of the stumpage should be included.

\section{Commissaries and Boarding Houses.}

Commissaries and boarding houses are usually conducted as independent enterprises, on a separate cost-paying or revenue-producing basis. They seldom form an integral part of lumbering operations. Investments in buildings and equipment f or these purposes which it is practicable to segregate will not ordinarily be taken into account in stumpage calculations. They may be included, however, if these features of the business are not handled independently.

Mill Sites and Rights of Way.

Expenditures for mill sites and rights of way are legitimate investments and should be included in the appraisal. Mill sites may have a speculative value apart from what they are worth for manufacturing lumber. This should be disregarded as far a possible, and the investment based upon a fair appraisal of the land for milling only. Mill sites will not ordinarily be depreciated, as it may fairly be assumed that the unimproved ground $w_{\perp} l l$ have the same value at the end of the operaticn as at its beginning.

Size and Type of Plants.

It is the policy of the Forest Service to favor small and medium-sized operations as far as practicable. Selection of the size and type of plants and investment calculations 
will be based upon such operations wherever they are practicable, and also upon methods of logging and manufacture tried out and established in the locality. Within these limitations, the investments taken should be based upon the most logical and efficient methods of exploitation. This applies to the size, type, and output of sawmills, the character and amount of logging equipment, and the nature of logging improvements. If larger operations are clearly the most practicable and logical, stumpage prices must be appraised accordingly. (See "Appraisalo for small sales," p. 47.)

Borrowed and Unborrowed Capital.

No distinction should be made between investments of borrowed and unborrowed capital. For the purpose of stumpage appraisals, capital obtained by credit dues the same work and is entitled to the same return as capital owned by the operator. The cost of obtaining capital is one of the elements entering into the margin for profit; and where this cost is high, as in the case of excessive local interest rates, the profit margin may properly be increased. (See p. 41.)

Classification of Investments.

The following classification of fixed investments will serve as a general standard for the Fore:t Service. Not all of the items will be required in every appraisal, and further subdivisions may be desirable in the more intensive and detailed calculations. The classification should thus be adjusted to fit special conditions, while preserving the main headings and their arrangement.

I. Investment-Logging.

(1) Logging improvements-Stump to landing-First cost of-

a. Chutes.

b. Roads.

c. Slides.

d. Landing improvements, or

$e$. Other structures used in skidding, hauling, or landing.

(2) Logging equipment-Stump to landing-First cost of-

a. Teams.

b. Sleds.

c. Big wheels.

d. Bummers or go-devils.

$e$. Donkey engines or steam skidders.

$f$. Overhead steam appliances.

g. Steam or horse loaders.

$h$. Woods tools, and

$i$. Any other logging equipment or appliances.

(3) Transportation improvements-Landing to mill, or mill to railroad shipping point-First cost of-

a. Railroads, including-

(a) Spurs and sidings.

(b) Roundhouses, coal bunkers, tanks, and other permanent structures.

b. Flumes.

c. Stream improvements.

d. Roads, or

e. Other transportation improvements.

(4) Transportation equipment-Landing to mill, or mill to shipping pointFirst cost of-

a. Railroad rolling stock, track tools, etc.

b. Marine equipment, tugs, bateaux, etc., and driving tools.

c. Teams, trucks and harness, sleighs, traction engines or other equipment, including hand tools, used in transporting timber from landing to mill, or mill to shipping point. 
I. Investment-Logging-Continued.

(5) Woods camps and other buildings, together with water system.

(6) Camp equipment-

a. Kitchen and mess equipment.

$b$. Bedding, heating equipment, and camp fittings.

(7) Repair equipment-Carpenter, blacksmith and machine shops, etc.

II. Investment-Manufacturing:

a. Site.

b. Pond and dam; other site improvements.

c. Sawmill.

(a) Building.

(b) Equipment.

(c) Power.

(d) Lath mill, etc.

d. Finishing plant.

(a) Building.

(b) Equipment.

(c) Power.

e. Dry kiln.

f. Waste burner.

g. Sheds, docks, platforms, pile bottoms.

$h$. Office and miscellaneous buildings.

i. Yard equipment.

j. Light, fire protection, etc.

\section{Depreciation of Fixed Investments.}

Depreciation is the shrinkage in the value of fixed investments on account of reduced utility or worth. Loss of value may be due to ordinary wear and tear, physical deterioration, or inadequacy for the current needs of an operation; or to the exhaustion of available timber supplies. In theory depreciation is a certain amount paid out of the proceeds of the business each year on the investment. The best concrete illustration is a sinking fund withdrawn from the proceeds of the business at regular intervals, deposited in a special account, and used to pay off bonds as they become due. In stumpage appraisals depreciation will be reckoned as if charged off and withdrawn from the business at the end of each year. It is a sum, prorated over every thousand feet of timber cut, which in the course of the operation pays back the reduction in value of the fixed investments.

\section{Rate of Depreciation.}

The rate of depreciation varies widely with the nature of the investment and character of its use. It is controlled by different factors in the case of the two main classes of fixed investments, viz, improvements and equipment.

Improvements are stationary structures which can be used only where they are built. They include all buildings except portahle camps, wagon and skid roads, railroad grades, cuts and fills, bridges, splash dams, etc. The rate of depreciation of each structure or improvement depends primarily upon the amount of timber which it can profitably be used to log. Its life is fixed by the time required to log the stumpage available. If all of the tributary timber is taken out during a particular sale, the improvement will have no residual value. Other structures favorably located with reference to large supplies of timber, like sawmills and logging railroads, may have a very long life. Their rate of depreciation will be correspondingly slow.

Equipment, on the other hand, can be moved from place to place. It includes tools, steam logging machinery, cables, railroad steel, teams, and rolling stock. Its depreciation depends primarily upon its resistance to wear and tear, or the length of its ordinary working life. Current industrial experience is the safest guide in calcu- 
lating the depreciation of equipment. The average working life of logging teams, for example, is commonly reckoned as 5 years. Steel rails are usually rated at a service of 20 years; but their depreciation during the first 10 years is at a much slower rate than during the second decade. This is on account of the market for second-hand rails which have been used but a few years. Donkey engines, on the other hand, have a very unstable value after any period of use, and must be depreciated more rapidly. The usual life of saw mill equipment is put at 20 years, but can be extended with higher charges for maintenance.

\section{Calculation of Depreciation.}

Depreciation is usually reckoned as an annual percentage of the total shrinkage in the value of the investment. This is frequently termed "straight line" depreciation. A clonkey engine with a life of 8 years and no value at the end of that time is thus reckoned as depreciating $12 \frac{1}{2}$ per cent of its first cost every year. A logging chute which can be used three years and will have no value thereafter will necessarily be depreciated $33 \frac{1}{3}$ per cent annually. A sawmill costing $\$ 30,000$, to be run for 10 years and valued at $\$ 10,000$ at the end of that period; will depreciate 10 per cent of the difference annually, or $\$ 2,000$.

The standard method followed in Forest Service appraisals will be to determine:

(1) The shrinkage in each item of investment from first cost to residual or wrecking value at the end of the operation, or whenever it goes out of use.

(2) The annual depreciation-that is, the total shrinkage divided by the number of years in the operation. If an investment is in use but part of an operation, its depreciation is thus averaged for simplicity over the whole period instead of the years of actual service only.

(3) The depreciation charge per thousand board feet log scale or other unit, found by dividing the annual depreciation by the yearly cut. Depreciation will always be prorated on $\log$ scale rather than mill tally. The same result is secured by dividing the total depreciation of the investment by the entire estimated cut.

As indicated on page 20 , a closer calculation may be used where the rate of depreciation varies from year to year, but for ordinary appraisals "straight line" depreciation is sufficieut.

\section{Determination of Residual or Wrecking Value.}

Residual or wrecking value is an uncertain factor. It should be used only where such a value will unquestionably exist at the end of the operation or sale contract. If no additional timber can be handled by the plant, it is obvious that a wrecking value only will remain. Railroads which will become common carriers with permanent traffic other than timber form the only exception to this rule. Railroad investments under such conditions can usually be regarded as not depreciating but as having a residual value equivalent to their first cost.

Where Other Timber is Available.

Where additional bodies of stumpage are available, a residual value should be credited to the fixed investments. It will ordinarily be the sum of (1) a proportion of the total depreciation similar to that which the remaining timber bears to the entire original stand, and (2) the wrecking value at the end of the operating life of the plant. To illustrate:

$\Lambda$ mill is to be built costing $\$ 35,000$ and capable of 15 years' operation at an annual capacity of $20,000,000$ feet. The estimated value of the site and scrap value of equipment is $\$ 5,000$, making the total depreciation $\$ 30,000$. A proposed sale of $160,000,000$ feet will supply it to capacity for eight years.

(1) If 140,000,000 feet of additional timber is available, or 7 years' cut, the residual value of the mill at the expiration of the sale will be $\frac{140}{300} \times \$ 30,000+\$ 5,000$, or $\$ 19,000$; and its depreciation in 8 years $\$ 16,000$, or $\$ 2,000$ annually. 
(2) If the available timber totals but $80,000,000$ feet, or 4 years' additional cut, the residual value will be $\frac{80}{240} \times \$ 30,000+\$ 5,000$, or $\$ 15,000$; and its depreciation in 8 years $\$ 20,000$, or $\$ 2,500$ annually.

The same process is applicable to investments in a railroad spur, wagon road, splash dam, or any other single logging improvement.

In lieu of a mathematical valuation, a business appraisal may be placed upon the plant at the expiration of the sale, based upon the probable conditions controlling its future operation or value in place.

\section{Amounts of Timber upon which Investments should be Depreciated.}

As far as practicable, it is the policy of the Forest Service to base depreciation upon the full operating life of the structure or equipment as fixed by normal industrial standards. Many timber sales are made for short periods which represent but a part of the efficient life of the mill, railroad, or other improvements. Future sales to such plants can not be guaranteed. The operator must protect himself in competition with other bidders for remaining blocks of stumpage tributary to his improvements. It is, however, the policy of the Forest Service to reserve from sale additional bodies of timber tributary to plants constructed in connection with short-term contracts until the initial chance is cut out. As far as practicable such reservations will be sufficient to insure the plant a normal operating life. Where additional National Forest timber is available, whether specifically reserved by the terms of sale or not, it should bear a proportionate part of the total depreciation of the plant.

\section{Inclusion of Private Timber in Reckoning Depreciation.}

Private timber which it is reasonable to believe the operator will handle and so located as to be most logically and economically logged by the same set of improvements should also carry its proportionate part of the total depreciation. This will hold whether the operation is chiefly in private timber, the purchase of small tracts of Government stumpage being a secondary feature, or whether a National Forest sale forms its principal supply and small quantities of private timber are available which it is reasonable to suppose the operator can secure. The bearing of private stumpage upon the depreciation of investments must therefore be carefully weighed.

\section{Depreciation in Sales to New Plants.}

If new mills or other improvements are to be constructed, a reasonable life in accordance with prevailing industrial standards will be allowed where sufficient Government timber, or private timber which there is reasonable likelihood of obtaining, is available. The total depreciation of improvements which can be used in logging and manufacturing such additional timber will be distributed over the entire amount of stumpage thus roughly blocked out to obtain the depreciation charge per thousand board feet.

\section{Relation of Depreciation to Residual Value.}

Extension of the depreciation over additional stumpage, aside from that on the sale area, is equivalent to calculating a residual value at the end of the first operation. In addition to the wrecking or scrap value of the plant at the end of its operating life, this residual value is a proportion of the total depreciation similar to that which the remaining available timber bears to the entire original stand. The determination of residual value thus has an important bearing upon depreciation.

\section{Investment and Depreciation ir Sales to Existing Plants.}

In sales to existing plants all improvements and equipment which will be used in the operation should be given a fair valuation. This applies fully as much to existing mills or partially used improvements as to new investments. In many cases an established operator with mills or improvements logically placed for exploiting the chance

$$
60813-14-2
$$


is a probable bidder. The fixed investment in such appraisals should be a valuation of existing improvements, with such additions as may be required for extensions or repairs. This conforms with the practice of allowing a residual value in sales to new plante which will command additional bodies of stumpage. In fact, the residual value of the established plant, with any further investments necessary, should be the basis of such appraisals.

\section{Valuation of Existing Improvements.}

The residual value of existing improvements is their sale value whenever obtainable. Otherwise, their first cost may be estimated and an operating life as fixed by industrial requirements and the amount of available timber. The wrecking value of any improvements at the end of the operation should be considered as in sales to new plants. From the estimated first cost, operating life, and wrecking value a fair annual depreciation can be readily obtained.

Short-cut methods of determining the residual value of existing plants, such as taking one-half or two-thirds of their first cost, may be used when justified by recognized practice. One-half the first cost of secondhand mills and other improvements in serviceable condition is usually a fair assumption, since it represents their average value throughout the total period of use.

\section{Where Several Plants are Competitors.}

When several existing plants are possible competitors for a chance, the residual value used in the appraisal should represent a fair average of the available improvements of the usual and efficient type. This may be calculated from (1) an average initital cost, (2) an average operating life, and (3) an average period of use prior to the purchase of Government stumpage. This process may be simplified where substantial accuracy can be secured by taking a fair proportion of the first cost of any local plant of the size and type required to handle the National Forest chance.

\section{Determination of Average Investment.}

Average investments in such operations upon which profit is calculated should be computed as indicated on page 22 , starting with the residual value of the improvements at the date when National Forest timber is purchased.

Use of Average Manufacturing Cost and Depreciation.

The foregoing is a general guide and statement of policy in sales to existing plants rather than an inflexible rule. In regions where manufacturing costs have been standardized by types of mills, and average figures covering the total cost of manufacture, depreciation included, are applicable within safe limits, they may be used in appraisals.

\section{Profit-Bearing Period of Investments.}

Fixed investments are seldom made in one lump at the outset of an operation. They usually begin in advance of cutting, depending upon the amount of preliminary construction which is required. In operations of any size and length additional investments become necessary from time to time, for railroad extensions, road or chute construction, more logging equipment, and the like. The replacement of major items of worn-out equipment, such as teams, rolling stock, and steam logging machinery, is an additional fixed investment. (See p. 7.) Many investments, furthermore, are used during only a part of the total operation.

\section{Interest Charges on Preliminary Investments.}

Interest should be allowed on money invested in improvements for ono or more years before cutting begins. The interest which has thus accumulated on preliminary investments on the date when their use begins will be treated in Service appraisals as an addition to the investment itself. Simple interest at 6 per cent will be used uniformly. If two years are required for the construction of improvements before 
beginning cutting, the amounts to be invested each year should be approximated. Twelve per cent of the first year's expenditure and 6 per cent of the second year's should be added to the estimated investments used in the appraisal.

Profit Only During Period of Actual Use.

Investments are entitled to profit only from the date when they are actually made. Investments in improvements or equipment which are abandoned or worn out before the end of the operatirin should be cut out of the profit-bearing capital at the proper time. Profit on invested money should thus be restricted to the period of its actual use. This can be done most conveniently by prorating short-term investments over the entire operation in making up the average profit-bearing capital. (See page 21.)

Calculation of Annual Depreciation and Average Investment.

Uniform methods of calculating fixed inve.tments and their depreciation are of obvious necessity. To this end, standard forms of tabulation will be of service. The essential facts to be determined are (1) the arerage profit-bearing capital at work in the business, and (2) the average annual depreciation of the fixed investments. It is of special importance to work out accurately the effect upon these two amounts of additinnal investments in improvements or equipment made from time to time and used during but a portion of the operation; and similarly of the retirement at various intervals of parts of the investment which are worn out or whose use is terminated.

\section{By Separate Years.}

The most exact method is to carry for each year of the operation (1) the investment required at the beginning of the year, (2) its depreciation during the year, and (3) additional investments necessary at the end of the year. The estimated depreciation during earh year is dedurted from the investment at its beginning. This figure, with the addition of any new outlays required during or at the end of the year, is the investment in the buiness at the beginning of the fullowing year. Thus is obtained the profit-bearing capital at the beginning of each year, with the average for the entire operation; the depresiation during each year and for the whole period; and the wrecking or residual value at its end.

This is illustrated by the following investments in logging equipment, consigting of a light locomotive, gypsy loader, donkey and yarding engines, blocks, and other rigging. Ten thousand five hundred dollars worth of machinery will be required for the first year's operation. - At the end of the first year, $\$ 1,200$ worth of additional equipment must be purchased; and at the end of the fifth year $\$ 1,800$ worth must be procured. Th's completes the equipment required for the entire 10 years. All of the machinery is depreciated at the rate of 10 per cent annually while in actual use.

Investment and depreciation-Logging equipment.

\begin{tabular}{|c|c|c|c|c|c|c|c|}
\hline Years. & $\begin{array}{l}\text { Profit- } \\
\text { bearing } \\
\text { invest- } \\
\text { ment. }\end{array}$ & $\begin{array}{c}\text { Depre- } \\
\text { ciation } \\
\text { during } \\
\text { year. }\end{array}$ & $\begin{array}{l}\text { Addi- } \\
\text { tional } \\
\text { invest- } \\
\text { ment- } \\
\text { end of } \\
\text { year. }\end{array}$ & Years. & $\begin{array}{l}\text { Profit- } \\
\text { hearing } \\
\text { invest- } \\
\text { ment. }\end{array}$ & $\begin{array}{l}\text { Depre- } \\
\text { ciat ion } \\
\text { during } \\
\text { year. }\end{array}$ & $\begin{array}{l}\text { Addi- } \\
\text { tional } \\
\text { invest- } \\
\text { ment- } \\
\text { end of } \\
\text { year. }\end{array}$ \\
\hline & \multirow{2}{*}{$\begin{array}{r}\$ 10,500 \\
10,650 \\
9,480 \\
8,310 \\
7,140 \\
7,770 \\
6,420\end{array}$} & \multirow{2}{*}{$\begin{array}{r}\$ 1,050 \\
1,170 \\
1,170 \\
1,170 \\
1,170 \\
1,350 \\
1,350\end{array}$} & \multirow{2}{*}{$\begin{array}{r}\$ 1,200 \\
\cdots \ldots \ldots \ldots \\
\cdots \cdots \\
\cdots, \ldots \ldots \\
1,800\end{array}$} & \multirow{2}{*}{ 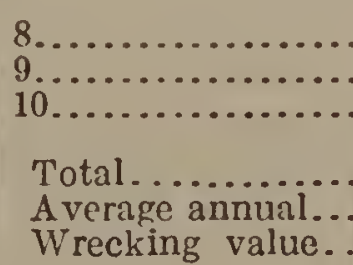 } & $\begin{array}{l}5,070 \\
3,720 \\
2,370\end{array}$ & $\begin{array}{l}1,350 \\
1,350 \\
1,350\end{array}$ & \\
\hline & & & & & $\begin{array}{r}71,430 \\
7,143\end{array}$ & $\begin{array}{r}12,480 \\
1,248\end{array}$ & $\$ 1,020$ \\
\hline
\end{tabular}

The first year's depreciation is 10 per cent of the initial investment, $\$ 10,500$. The second, third, fourth, and fifth year's depreciation is the same amount plus 10 per cent of the additional investment of $\$ 1,200$. The depreciation during the sixth and each 
subsequent year is the sum of these two amounts plus 10 per cent of the further investment of $\$ 1,800$.

The wrecking value of $\$ 1,020$ is the difference between the investment at the beginning of the last year and the depreciation during that year. This is made up of 10 per cent of the $\$ 1,200$ investment, which was in use 9 years, and 50 per cent of the $\$ 1,800$ investm ?nt, which was in use 5 years. The average profit-bearing capital re prese nted by this equipment is thus $\$ 7,143$. The average yearly depreciation to be prorated over the annual cut is $\$ 1,248$.

\section{Where Depreciation is Irregular.}

This method is of special service in the case of investments whose depreciation from y ear to year is irregular rather than at a uniform rate, or "straight line." The following will illustrate:

In the same 10-year operation, the estimated cost of steel rails, fastenings, and $\mathrm{s}$ witches for the first year's logging is $\$ 6,500$. Extensions of permanent way and spur $\mathrm{s}$ for the second year's logging require an additional investment of $\$ 2,100$; for the third year, $\$ 1,700$; and for the fifth year, $\$ 3,200$. Further investments are unnecessary until the end of the seventh year, when $\$ 4,000$ worth of additional steel must be purchased.

All of this steel has a life of 20 years. During the first 5 years of use it depreciates in value at the rate of but 1 per cent annually; and during the second 5 years at the rate of 2 per cent annually. These rates are determined by the local market for "relaying rails," first and second class respectively. The annual depreciation charges are thus calculated at 1 per cent of each of the several investments during its first 5 years of use, and 2 per cent during the remaining period, all items being rounded off to the nearest dollar. For the last year, a charge of $\$ 1,200$ for lifting the steel and removing it to the nearest shipping point is included in the depreciation. The profit-bearing investment at the beginning of each year is figured as before by adding the new investment at the end of the preceding year, if any, and deducting the depreciation during that year.

Investment and depreciation-Railroad steel.

\begin{tabular}{|c|c|c|c|c|c|c|c|}
\hline Years. & $\begin{array}{c}\text { Profit- } \\
\text { bearing } \\
\text { invest- } \\
\text { ment. }\end{array}$ & $\begin{array}{l}\text { Depre- } \\
\text { ciation } \\
\text { during } \\
\text { year. }\end{array}$ & $\begin{array}{l}\text { Addi- } \\
\text { tional } \\
\text { invest- } \\
\text { ment- } \\
\text { end of } \\
\text { year. }\end{array}$ & Years. & $\begin{array}{c}\text { Profit- } \\
\text { bearing } \\
\text { invest- } \\
\text { ment. }\end{array}$ & $\begin{array}{l}\text { Depre- } \\
\text { ciation } \\
\text { during } \\
\text { year. }\end{array}$ & $\begin{array}{l}\text { Addi- } \\
\text { tional } \\
\text { invest- } \\
\text { ment- } \\
\text { end of } \\
\text { year. }\end{array}$ \\
\hline \multirow[t]{2}{*}{$\begin{array}{l}1 \\
1 \ldots \ldots \ldots \ldots \\
2 \\
3 \ldots \ldots \ldots \ldots \ldots \\
4 \ldots \ldots \ldots \ldots\end{array}$} & \multirow{2}{*}{$\begin{array}{r}\$ 6,500 \\
8,535 \\
10,149 \\
10.046 \\
13,143 \\
13,008 \\
12.808\end{array}$} & \multirow{2}{*}{$\begin{array}{r}\$ 65 \\
86 \\
103 \\
103 \\
135 \\
200 \\
221\end{array}$} & \multirow[t]{2}{*}{$\begin{array}{r}\$ 2,100 \\
1,700 \\
\cdots \ldots, \ldots \\
3,200\end{array}$} & \multirow{2}{*}{ 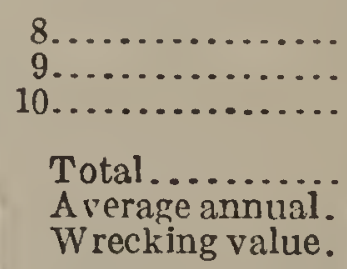 } & $\begin{array}{r}\$ 16.587 \\
16.309 \\
16,031 \\
\end{array}$ & $\begin{array}{r}\$ 278 \\
278 \\
1.510 \\
\end{array}$ & \\
\hline & & & & & $\begin{array}{r}123,116 \\
12,312\end{array}$ & $\begin{array}{r}2,979 \\
298\end{array}$ & $\$ 14,521$ \\
\hline
\end{tabular}

The wrecking value consists of-

85 per cent of the first in vestment........................ $\$ 6,500$

87 per cent of the second investment.......................... 2,100

89 per cent of the third investment........................... 1.700

93 per cent of the fourth investment.......................... 3,200

97 per cent of the last investment............................. 4,000

Less cost of putting the steel on the market at the end of the operation....... 1,200

Where Successive Investments of Varying Life are Made.

The method may be further illustrated by the outlays for constructing roadbed, placing ties, laying steel, and ballasting in the same 10-year operation, improvements which are abandoned in the course of logging and hence must be wholly depreciated. 
The estima ted cost of roadbed, ties, and laying steel for the first year's logging is $\$ 4,500$. This portion of the railroad will be in use throughout the entire operation. Subsequent investments in roadbed, ties, and labor for laying rails, with the estimated period of lise in each instance, are as follows:

\begin{tabular}{|c|c|c|c|c|c|}
\hline Years. & $\begin{array}{l}\text { Invest- } \\
\text { ment. }\end{array}$ & $\begin{array}{l}\text { Period } \\
\text { of use. }\end{array}$ & Years. & $\begin{array}{l}\text { Invest- } \\
\text { ment. }\end{array}$ & $\begin{array}{l}\text { Period } \\
\text { of use. }\end{array}$ \\
\hline $\begin{array}{l}\text { Second ........ } \\
\text { Third } \ldots . . . . . \\
\text { Fourth....... } \\
\text { Fifth............. }\end{array}$ & $\begin{array}{r}\$ 1,800 \\
1,100 \\
1,600 \\
2,100\end{array}$ & $\begin{array}{r}\text { Years. } \\
2 \\
1 \\
2 \\
1\end{array}$ & $\begin{array}{l}\text { Sixth..... } \\
\text { Seventh.. } \\
\text { Fighth... } \\
\text { Ninth.... }\end{array}$ & $\begin{array}{r}\$ 1,500 \\
2,200 \\
1,700 \\
2,500\end{array}$ & Years. \\
\hline
\end{tabular}

No additional investment is required for the tenth year's operation.

Each investment for railruad construction must be depreciated during the period of its actual use. The first year's outlay will thus be depreciated at the rate of one-tenth annually throughout the entire operation; the second at one-half annually during the second and third years; the third wholly during the year following the investment; and so on. The detailed calculation follows:

Investment and depreciation-Roadbed.

\begin{tabular}{|c|c|c|c|c|c|c|c|}
\hline Years. & $\begin{array}{l}\text { Proflt- } \\
\text { bearing } \\
\text { invest- } \\
\text { ment. }\end{array}$ & $\begin{array}{l}\text { Depre- } \\
\text { ciation } \\
\text { during } \\
\text { year. }\end{array}$ & $\begin{array}{l}\text { Addi- } \\
\text { tional } \\
\text { invest- } \\
\text { ment- } \\
\text { end of } \\
\text { year. }\end{array}$ & Years. & $\begin{array}{l}\text { Profit- } \\
\text { bearing } \\
\text { invest- } \\
\text { ment. }\end{array}$ & $\begin{array}{l}\text { Depre- } \\
\text { ciation } \\
\text { during } \\
\text { sear. }\end{array}$ & $\begin{array}{l}\text { Addi- } \\
\text { tional } \\
\text { invest- } \\
\text { ment- } \\
\text { end of } \\
\text { year. }\end{array}$ \\
\hline & \multirow{2}{*}{$\begin{array}{r}\$ 4,500 \\
5,850 \\
5,600 \\
4,750 \\
5.600 \\
3,750 \\
5,200\end{array}$} & \multirow{2}{*}{$\begin{array}{r}\$ 450 \\
1,350 \\
2.450 \\
1.250 \\
3,350 \\
750 \\
1,850\end{array}$} & \multirow{2}{*}{$\begin{array}{l}\$ 1,800 \\
1,100 \\
1,600 \\
2.100 \\
1,500 \\
2,200 \\
1,700\end{array}$} & \multirow{2}{*}{ 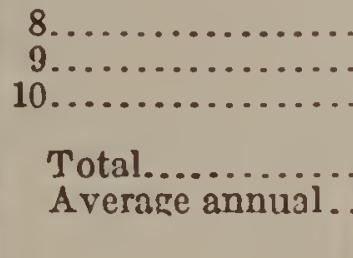 } & $\begin{array}{r}\$ 5,0.50 \\
4,000 \\
2,000\end{array}$ & $\begin{array}{r}\$ 3,550 \\
2.000 \\
2,000 \\
\end{array}$ & 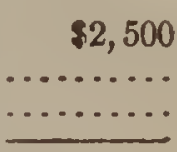 \\
\hline & & & & & $\begin{array}{r}46,300 \\
4,630\end{array}$ & $\begin{array}{r}19.000 \\
1,900\end{array}$ & \\
\hline
\end{tabular}

Thus, while $\$ 19,000$ is invested all told in the various railroad grades and must be depreciated on the timber handled, the average profit-bearing capital tied up in such improvements is but $\$ 4,630$. The entire original outlay is returned in the accu mulated depreciation charges.

Calculation by Investment Items.

A simpler and quicker method is to calculate for each improvement or purchase of equipment the yearly depreciation and the average profit-bearing investment, both prorated over the entire operation. Yearly depreciation is determined by dividin the total shrinkage in the value of the improvement or equipment by the number of years in the operation. The average profit-bearing investment is determined by the following formula:

One-half of the sum of the initial investment and its residual or wrecking value multiplied by a fraction whose numorator is the number of years during which the particular improvement or equipment is in use and whose denominator is the total number of years in the operation, plus one-half of the yearly depreciation.

Wherever depreciation takes place in a "straight line" - that is, at a uniform rate annually during the period of use-this method yields the same results as the preceding calculation. If depreciation does not progress at a uniform rate throughout the period of use, it vields a lower average investment. A uniform rate of depreciation can be fairly assumed, however, in most investments, and is the more common undustrial practice. 
The addition of one-half of the annual depreciation in obtaining the average profitbearing capital under earh item of investment is based on the assumption that depre ciation is charged off at the end of each year rather than currently during the year. This is equivalent to calculating the average investments as at the beginning of each of the respective years in the operation rather than at the middle of the year. To illustrate:

A $\$ 10,000$ investment is to be wholly depreciated in 10 years, at $\$ 1,000$ annually. The successive investments at the beginning and middle of each year are:

\begin{tabular}{|c|c|c|}
\hline & Beginning. & Middle. \\
\hline 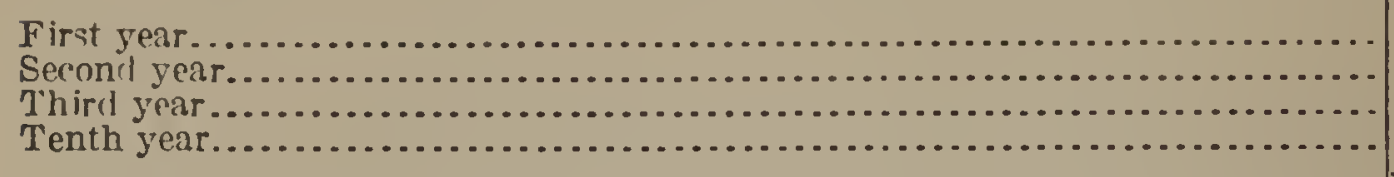 & $\begin{array}{r}\$ 10,000 \\
9,000 \\
8,000 \\
1,000 \\
\end{array}$ & $\begin{array}{r}\$ 9.500 \\
8.500 \\
7,500 \\
500 \\
\end{array}$ \\
\hline 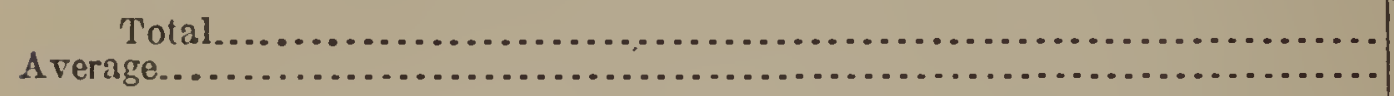 & $\begin{array}{r}55,000 \\
5,500\end{array}$ & $\begin{array}{r}50.000 \\
5,000\end{array}$ \\
\hline
\end{tabular}

An average for the beginning of each year is obtained under the formula by taking one-half the sum of the initial investment and residual value $(\$ 10,000+0)$, together with one-half of the annual depreciation, $\$ 1,000$. The addition of one-half of the annual depreciation thus results in a figure representing the investment during a 12-month interval.in the exact center of the operating period, or the true mathematical average.

This treatment of depreciation is not strictly applicable to all operations. It is, however, the more conservative basis of determining average investments and will therefore be followed uniformly in Service appraisals.

The calculation of average depreciation and profit-bearing capital by each investment item will be of more general service because of its shorter and eimpler form than the other method of calculation, by separate years.

The example given on page 19 recast in this form is as follows:

Investment and depreciation-Logging equipment.

\begin{tabular}{|c|c|c|c|c|}
\hline Years of use. & $\begin{array}{l}\text { Initial } \\
\text { invest- } \\
\text { ment. }\end{array}$ & $\begin{array}{l}\text { Yearly } \\
\text { deprecia- } \\
\text { tion. }\end{array}$ & $\begin{array}{c}\text { Wrecking } \\
\text { value. }\end{array}$ & $\begin{array}{l}\text { A verage } \\
\text { profit- } \\
\text { bearing } \\
\text { invest- } \\
\text { ment. }\end{array}$ \\
\hline $\begin{array}{l}10 \ldots \ldots \ldots \ldots \ldots \ldots \\
9 \ldots \ldots \ldots \ldots \\
5 \ldots \ldots \ldots \ldots \ldots \ldots\end{array}$ & $\begin{array}{r}\$ 10,500 \\
1,200 \\
1.800\end{array}$ & $\begin{array}{r}\$ 1,050 \\
108 \\
90\end{array}$ & $\begin{array}{r}\$ 120 \\
900\end{array}$ & $\begin{array}{r}\$ 5,775 \\
648 \\
720\end{array}$ \\
\hline Total........ & 13,500 & 1,248 & 1,020 & 7,143 \\
\hline
\end{tabular}

The same results are obtained as under the former method.

The annual depreciation of the first item is one-tenth of the initial investment; of the second, one-tenth of a total shrinkage of $\$ 1,080$; of the third, one-tenth of a total shrinkage of $\$ 900$.

The average interest-bearing investment under the first item is-

under the second-

$$
\frac{10}{10} \times \frac{10,500}{2}+\frac{1,050}{2} \text {; }
$$

under the third-

$$
\frac{9}{10} \times \frac{1,200+120}{2}+\frac{108}{2} \text {; }
$$

$$
\frac{5}{10} \times \frac{1,800+900}{2}+\frac{90}{2} \text {. }
$$


The calculation of investments in roadbed, ties, and laying steel, on page 21 , recast in this form is as follows:

\begin{tabular}{|c|c|c|c|c|c|c|c|}
\hline Years of use. & $\begin{array}{l}\text { Initial } \\
\text { invest- } \\
\text { ment. }\end{array}$ & $\begin{array}{l}\text { Yearly } \\
\text { deprecia- } \\
\text { tion. }\end{array}$ & $\begin{array}{l}\text { Average } \\
\text { profit- } \\
\text { bearing in- } \\
\text { vestment. }\end{array}$ & Years of use. & $\begin{array}{l}\text { Initial } \\
\text { invest- } \\
\text { ment. }\end{array}$ & $\begin{array}{l}\text { Yearly } \\
\text { deprecia- } \\
\text { tion. }\end{array}$ & $\begin{array}{l}\text { Average } \\
\text { profit- } \\
\text { bearing in- } \\
\text { vestment. }\end{array}$ \\
\hline $\begin{array}{l}10 . \\
2 . \\
1 .\end{array}$ & \multirow{2}{*}{$\begin{array}{r}\$ 4,500 \\
1,800 \\
1,100 \\
1,600 \\
2,100 \\
1,500\end{array}$} & \multirow{2}{*}{$\begin{array}{r}\$ 450 \\
180 \\
110 \\
160 \\
210 \\
150\end{array}$} & \multirow{2}{*}{$\begin{array}{r}\$ 2,475 \\
270 \\
110 \\
240 \\
210 \\
450\end{array}$} & \multirow{2}{*}{$\begin{array}{r}2 \\
\quad \text { Total } . . .\end{array}$} & $\begin{array}{r}\$ 2,200 \\
1,700 \\
2,500 \\
\end{array}$ & $\begin{array}{r}\$ 220 \\
170 \\
250\end{array}$ & $\begin{array}{r}\$ 330 \\
170 \\
375\end{array}$ \\
\hline & & & & & 19,000 & 1,900 & 4,630 \\
\hline
\end{tabular}

The results are the same as those obtained in the first calculation. The average interest-bearing investment is computed for each item, as 10/10,2/10,1/10, etc., of one-half of the initial outlay, this being a 10 -year operation, plus one-half of the yearly depreciation.

The following illustration shows the application of this method to a complicated railroad investment, parts of which are made and withdrawn at irregular intervals:

A main railroad must be built at the outset of a 20-year operation, at a cost of $\$ 72,000$. Two years will be required for its construction before cutting begins, approximately one-fourth of the amount being expended during the first year and three-fourths during the second year. In terest on these amounts at 6 per cent $(\$ 18,000$ for two years and $\$ 54,000$ for one year) will be included as part of the initial investment, which thus aggregates $\$ 77,400$. It will be fully depreciated in the 20 years' operation.

The main railroad suffices for logging during the first two years. Three miles of spurs are then required, to be used four years and abandoned. The estimated cost is $\$ 2,000$ per mile for roadbed, ties, and labor and $\$ 2,400$ per mile for steel. Five miles of additional spurs will then be necessary. This will necessitate the purchase of steel for 2 miles, at $\$ 2,400$, and an outlay for roadbed, ties, and labor for 5 miles, estimated at $\$ 1,800$ per mile. These spurs are to be used four years, by which time the timber tributary to them will be cut out.

Six miles of spurs into other units must then be graded and laid. The roadbed and labor in track laying are estimated at $\$ 1,500$ per mile. One additional mile of steel must be purchased at a cost of $\$ \_, 400$. This section of track will supply logs for five years. Extensions aggregating 3 miles must then be provided for the last five years' logging, the 6 miles previously constructed remaining in use. The extensions are estimated to cost $\$ 2,000$ per mile for roadbed, labor, etc., and $\$ 2,400$ for steel.

The investments in roadbed will be without value at the end of the operation and must therefore be wholly depreciated. All investinents in steel rails will be depreciated at 5 per cent annually, leaving a wrecking value, for second-hand rails, in the case of steel used during but a portion of the operation.

These investments may be tabulated as follows:

\begin{tabular}{|c|c|c|c|c|}
\hline Years of use. & $\begin{array}{l}\text { Initial in- } \\
\text { vestment. }\end{array}$ & $\begin{array}{l}\text { Yearly de- } \\
\text { preciation. }\end{array}$ & $\begin{array}{l}\text { Wrecking } \\
\text { value. }\end{array}$ & $\begin{array}{l}\text { Average } \\
\text { profit-bear- } \\
\text { ing invest- } \\
\text { ment. }\end{array}$ \\
\hline 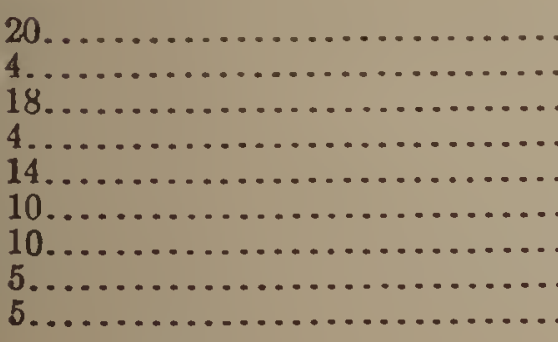 & $\begin{array}{l}\$ 77,400 \\
16,000 \\
27,200 \\
19,000 \\
24,800 \\
19,000 \\
22,400 \\
16,000 \\
27,200\end{array}$ & $\begin{array}{r}\$ 3,870 \\
300 \\
324 \\
450 \\
168 \\
450 \\
60 \\
300 \\
90\end{array}$ & 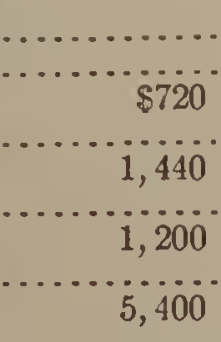 & $\begin{array}{r}\$ 10,635 \\
750 \\
3,726 \\
1,125 \\
2,268 \\
2,475 \\
930 \\
900 \\
1,620\end{array}$ \\
\hline Total...... & 129,000 & 6,012 & 8,760 & 54,429 \\
\hline
\end{tabular}


Of the investments made at the beginning of the third year, for example, the roadbed is in use four years and the steel is years. The average yearly investment for this piece of roadbed is therefore computed as $\frac{4}{20} \times \frac{6000}{2}+\frac{300}{2}$; for the steel as $\frac{18}{20} \times \frac{7200+720}{2}+\frac{324}{2}$. It is seen that while $\$ 129,000$ is invested in the operation at different times, the average capital at work in the business and entitled to profit is $\$ 54,429$. The entire $\$ 129,000$ is returned, however, by a depreciation charge of $\$ 6,012$ annually for 20 years and the wrecking value of $\$ 8,760$ at the end of the operation.

It will be noted that the dates when particular investments are made and withdrawn are of no consequence. The telling factor is the number of years during which each investment is at work.

\section{OPERATING COSTS.}

\section{Standard Classificatlon.}

The following classification of operating. costs will be used as standard by the Forest Service. Not all of its items are applicable in every appraisal and further subdivision may be necessary in some instances. The main classification should, however, be uniformly used.

\section{Classification of operating costs.}

1. Logging.

(1) Stump to landing.

a. Felling.

b. Bucking.

c. Swamping.

d. Trimming, peeling, and sniping (included in swamping or yarding as case may be).

e. Skidding or yarding.

f. Hauling, chuting, roading, etc.

$g$. Decking or piling at yards.

$h$. Maintenance-supplies and repairs.

i. Supervision. ${ }^{1}$

(2) Landing to mill.

a. Loading, breaking out landings, or other work at landing itself.

b. Scaling.

c. Railroading, hauling, driving, fluming, or other transportation charges.

d. Unloading at mill pond or yard.

e. Maintenance-supplies and repairs.

f. Supervision. ${ }^{1}$

(3) Extra costs of logging under Forest Service regulations.

a. Cutting of timber under protection requirements.

(a) Net cost of cutting diseased trees (deducting yield in merchantable logs) prorated over entire cut.

(b) Net cost of cutting snags (deducting yield in merchantable logs) prorated over entire cut.

b. Slash disposal.

(a) Brush piling.

(b) Burning piled or loose slash.

(c) Clearing firebreaks.

(d) Burning slash as cut.

1 Use one supervision item for logging and woods work if preferred. 
2. Manufacture, mill pond to f. o. b. cars.

(1) Sawmill.

a. Pond, handling logs in pond and putting on jack chain (labor).

b. Sawing, from log on jack chain until lumber leaves trimmers (labor).

c. Sorting, carrying lumber to transfer chains, buggies or rolls, including grading and tallying (labor).

d. Power (labor).

e. Maintenance.

Supplies.

Repairs (labor and materials).

$f$. Millwright (labor).

g. Filing (labor).

$h$. Oiling (labor).

(2) Yard.

a. Transportation to yard, taking lumber from transfer chains, buggies, or rolls, or on delivery from kiln or planer, to piles.

b. Handling, piling, etc., exclusive of loading (labor).

c. Maintenance.

Supplies.

(3) Kiln.

Repairs (labor and materials).

a. Transportation to kiln.

b. Handling (labor).

c. Power (labor).

d. Maintenance.

Supplies.

Repairs (labor and materials).

(4) Planing mill.

a. Transportation to planing mill.

$b$. Handling (labor).

c. Power (labor).

d. Maintenance.

Supplies.

Repairs (labor and materials).

(5) Sheds. ${ }^{1}$

$a$. Transportation to sheds.

b. Handling (labor).

(6) Loading.

a. Transportation to cars, including taking down yard piles, repiling in cars, etc.

3. Sales.

b. Handling (labor).

(1) Traveling salesmen.

(2) Commissions.

(3) Advertisements.

(4) Retail yards. ${ }^{2}$

4. Taxes and insurance.

(1) Taxes.

a. On permanent improvements, including franchise taxes.

b. On movable equipment.

c. On logs.

d. On lumber (yard stock).

1 Include under "Yard" if desirable.

2 The operation should be carried through to retail yards only when the organization of a specific plant makes this necessary to a proper analysis of costs and returns. As far as practicable, returns will be based upon wholesale prices f. o. b. cars at nearcst common carrier shipping point. (See p. 34.) 
4. Taxes and insurance-Continued.

(2) Insurance.
a. On logs.
b. On lumber.
c. On permanent improvements.
d. On equipment.
$e$. Liability insurance for injuries to workmen.

5. General expense.

(1) Cruising and layout of operation, surveys, etc.

(2) Protection of sale area from fire.

(3) Office expenses.
a. Timekeeping.
b. Clerical help.
c. Stationery, postage, telegrams, etc.
d. Rentals, lighting, water rents, telephone service, etc.
e. Association dues, etc.

(4) Fees and other expenses in employing labor.

(5) Supervision: Salaries and expenses of administrative force, including foremen whose time is not wholly chargeable to specific operations.

Necessity for Ascertaining all Operating Costs.

The chief purpose of this detailed enumeration is to cause appraisers to study all features of an operation thoroughly and take all necessary costs into account. Caution under this head applies particularly to supervisory costs, selling expenses, the cost of employing and insuring labor and like items which do not appear on the face of current work. Study of running operations is the only safe guide to many of these items. Their inclusion in the calculation in accordance with prevailing industrial conditions and practice is essential to an accurate appraisal.

Use of Conservative Figures.

Costs should be fairly and liberally reckoned. Men watching going operations are inclined to figure too closely, taking standards which are not practicable in a season's run and overlooking the delays and losses of close connection which occur between constituent portions of the work. The costs used should be practicable under continuous operation for a long period. They should check with going figures at which operations for a season or more are being conducted by reasonably efficient concerns. The aim will be to strike a fair average under which the inefficient operator must stand the losses due to his inefficiency, while the exceptionally able lumberman will make a higher profit on account of his special skill or ability.

\section{Checks from Jobbing Rates and Going Operations.}

A detailed classification of operating costs should be presented in the appraiser's report. Checks by sections of the work, such as the cost of loading, hauling, and landing logs on a given haul, or the total cost of logging or milling, should be obtained from going operations in similar timber wherever possible. Current jobbing rates, if available, also serve as useful checks. Any such rates or average costs must, of course, be authentic.

Milling costs tend to be much more uniform over a considerable region and much more susceptitle of standardization than logoing costs. In many manufacturing districts, with well-definerl types of mills, average figures may be had for the total cost of manufacture and sale, including mill depreciation and maintenance. These are the more trustworthy when embolying the experience of a number of operators, and if well established may be substituted for estimates of the same items in stumpage appraisals. Superintendence, selling costs, and other general expense items also tend to be the same in plants of the same general size and type and can often be standardized to advantage for considerable regions. 


\section{Extra Costs of Service Requirements.}

It is important to give full weight to the added costs of operation due to requirements imposed by the Forest Service. These should be estimated separately for items like brush disposal, which are readily segregated from other operating costs. The extra cost, of other requirements, such as reserving a portion of the timber, should be included in the cost of the particular step in the operation to which the requirement applies. In other words, the cost of each process should be estimated as the Service will require the work to be done. The appraiser's report may well contain, however, a summary of the effect of all Service requirements upon operating costs and investments for the information of prospective purchasers.

Expenditures under such requirements which are made currently in connection with other woods operations call for a sum of working (apital analogous to that for logging costs and having the same turnover (See p. 29.) Other expenditures, particularly brush burning, may be incurred after the logs are removed, or indeed after the lumber has been manufactured and sold. Such expenditures are paid out of returns for the product and require little or no additional working capital.

Basis of Computation.

Logging and transportation costs to the mill will be computed on log scale; milling costs on lumber tally. This accords with trade practice and facilitates allowance for overrun.

\section{Distinction Between Operating Costs and Fixed Investments.}

Expenditures for temporary improvements. such as chutes or roads in use for a year or less, may be charred either as fixed investments cr operating costs. The difference in the resulting appraisal is unimportant. If classed as investments they increase the charges lor depreciation and profit on fixed investments. If (lassed as operating costs, they increase this item, together with working capital and the profit earned hy it.

Tn illustrate- $\$ 1,000$ is to be expended during a logging season for temporary truck roads in an operation cutting $5,000,000$ feet annually. As an investment. this outlay adds 20 cents per thousand feet to the depreciation and 4 cents per thousand feet to the profit, figuring the latter at 20 per cent on the invested capital. As an operating cost, it adds 20 cents per thousand feet to the current charges and 4 cents to the profit on working capital, assuming but one turn annually for the expenditure and the same profit rate.

\section{Period of Use the Deciding Factor.}

The period of use of the structure or material should be the deciding factor. In Forest Service practice all expenditures for improvements or equipment used for one year or less and having no residual or wrecking value will be classed as operating costs. Improvements and equipment used for longer periods or which will have a residual or wrecking value at the end of the operation will be classed as fixed investments.

\section{Maintenance.}

Maintenance is often confused with depreciation, but should be kept distinct. It is a current charge for blacksmith and machine shops, section crews on railroads, millwrights, repair kits, supplies, etc., expended solely for the upkeep and repair of existing structures or equipment. It varies greatly with different improvements or kinds of equipment, depending upon their nature and the amount and severity of use.

A locomotive, for example, has a first cost of $\$ 9,000$, a life of 12 years, and an estimated scrap value at the end of that time of $\$ 600$. The depreciation charge necessary to restore the original investment is thus $\$ 8,400$, or $\$ 700$ a year; $\$ 200$ additional may be required annually, however, for machine-shop work, replacement of minor parts, etc. The latter is maintenance. 


\section{Maintenance of Mills.}

Maintenance is always an important and unavoidable charge in milling, on account of the constant repairs, alteration of machinery, etc., necessary in keeping up an efficient mill. The depreciation of a mill, however, where large supplies of timber insure long life, may be very small. Generally speaking, as the depreciation of mills and other machinery is reduced-that is, as a longer operating life is assured-expenditures for maintenance must be increased because of the greater average amount of repairs and replacements required. Average maintenance costs for different kinds of improvements and equipment can best be obtained from local experience in similar operations.

\section{Selling Costs.}

Selling costs are specialized and vary with the character of the operation. In most small plants the mill cut is either contracted in advance or sold to local buyers, selling costs being largely or wholly eliminated. Large plants with extensive yard stocks which sell their cut in competitive territory, on the other hand, may incur very high selling costs. This charge can be determined only from local trade conditions. It can be handled best by establishing average selling charges for the principal types of plants in each locality, classified by output or by other industrial factors which affect this item.

\section{Taxes and Insurance.}

Taxes and insurance are grouped apart from general expense to facilitate the determination of working capital. Prevailing tax assessments on the forms of property carried in a lumber operation, as percentages oi their actual or sale value, and tax levies on assessed valuation can usually be obtained directly from the county authorities. Insurance rates are usually standardized for the various forms of propertymills, lumber in yards, etc. Local practice will be the best index to the proportion of the value of the particular class of improvements or other property on which insurance is carried. Liability insurance, to cover injuries to workmen, should similarly be estimated in accordance with the common practice in this regard.

\section{General Expense-Superintendence.}

The principal general expense charge is superintendence. The supervision of each portion of the work, as logging from stump to landing, should be included in the cost of that part of the operation. General expense should include only superintendence which applies to the entire organization and can not practicably be segregated between its parts.

General expense charges are the least tangible of any in the operation and the most easily overlooked. Their inclusion in the calculation is as important, however, as the cost of felling or skidding. Careful study of the organization of existing operations, the cost of superintendents and other executive officers, and of necessary office expenses is essential to gauge these items accurately in stumpage appraisals.

\section{Elements in Working Capital.}

\section{WORKING CAPITAL.}

Operating costs are paid either from working capital or directly from the proceeds of sales.

Working capital thus depends upon two elements (1) the amount of current expenditures, and (2) the time which elapses between outlay and realization. While the amount of such capital actually in use varies from month to month, it will for appraisal purposes be regarded as a constant fund fixed in accordance with the average requirements of the business. This accords with the common business practice of carrying short-term notes for periods when special demands must be met and a corresponding balance when sales are most active. Working capital is entitled to regular yearly. profit and must be found intact at the end of the operation. It is entirely separate from fixed investments and has no relation to depreciation. 


\section{Variation in Different Operations.}

The amount of working capital required varies widely in accordance with the product of the operation, the methods of marketing it, and the local logging conditions and trade practices. Uniform methods of calculation are not practicable in stumpage appraisals. The following discussion is intended to suggest ways of determining working capital rather than to establish hard and fast rules. The experience of operators is the best aid in estimating working capital and should be obtained whenever possible.

\section{Frequency of the Turn.}

The factors which bear most directly upon the amount of working capital needed in an operation are (1) the total sum of annual operating costs and stumpage payments, and (2) the average period between expenditures for these purposes and corresponding returns from sales of the product. Broadly speaking, the working capital must be equivalent to three-fourths, one-half, or one-third of the total expenditures each year for operating costs and stumpage payments if the average period between outlay and realization is nine months, six months, or four months, respectively. Where an annual $\log$ drive is required, working capital may be turned but once a year. With railroad logging and quick sales it may be turned as often as once a month. In exceptional cases manufacture and sale follow logging so quickly that labor and supply bills can be paid directly with a portion of the returns, and working capital is largely eliminated.

\section{Working Capital Required for Taxes and Insurance.}

Taxes and insurance become due at specified dates each year and in a continuous operation are repaid gradually from sales throughout the year. It is a fair assumption, therefore, that a fund of working capital equivalent to one-half the yearly taxes and insurance must be kept on hand.

\section{For Accounts Receivable.}

In ordinary lumber marketing, freight is prepaid by the seller and the account carried for 30 or 60 days, or the bill is discounted for cash payment. The former practice, which is far more common, requires cash to carry the operation until the proceeds of sales are actually in hand and available for use in the business. The latter is a universal trade method of securing immediate returns by sacrificing a small portion of them. The discount is thus a means of reducing working capital.

Accounts receivable are often covered by short-term loans. Since no distinction is made in Service appraisals between borrowed and unborrowed capital, however, and all the funds actually required in the business must be provided for, such accounts should be included in the estimate of working capital. This item should be figured very conservatively either $(1)$ by including the average period between sale and payment in the "turn" of the operating costs and stumpage payments, or (2) by adding to the working capital as otherwise made up the running average of credits outstanding one month or more in operations of similar type and output.

Since credit accounts are provided for in the profit-bearing investment, neither interest on them nor trade discounts, which often appear in cost statements, will be included in the operating charges. Any costs or losses incurred in such financial arrangements are fully. compensated by the profit thus allowed.

\section{Determination of Working Capital.}

These principles may be illustrated by the following operation on the West Coast. It is estimated that sufficient working capital must be on hand to run the logging camp three months and the mill two months before funds are returned from sales in sufficient amounts to carry the business; that is, it is necessary to have a continuous supply of logs equal to the camp's output for one month at the landing, in transit, or at the mill, and an average yard stock of lumber equal to the output of the mill for two months. Payments for lumber will be made in time to cárry the cost of the fourth month's logging and third month's milling. The working capital used in logging is thus turned 
four times a year and that used in milling six times, with the exception of funds carried to pay taxes and insurance in each instance, which are reckoned as turning twice annually.

The working capital required in this operation may be summarized as follows:

\begin{tabular}{|c|c|c|c|c|}
\hline Expenditure. & $\begin{array}{l}\text { Amount } \\
\text { per thousand } \\
\text { feet. }\end{array}$ & $\begin{array}{l}\text { Portion } \\
\text { paid from } \\
\text { working } \\
\text { capital. }\end{array}$ & $\begin{array}{l}\text { Number of } \\
\text { times work- } \\
\text { ing capital } \\
\text { is turned } \\
\text { annually. }\end{array}$ & $\begin{array}{l}\text { orking cap- } \\
\text { ital required } \\
\text { per thousand } \\
\text { feet } \\
\text { annually. }\end{array}$ \\
\hline 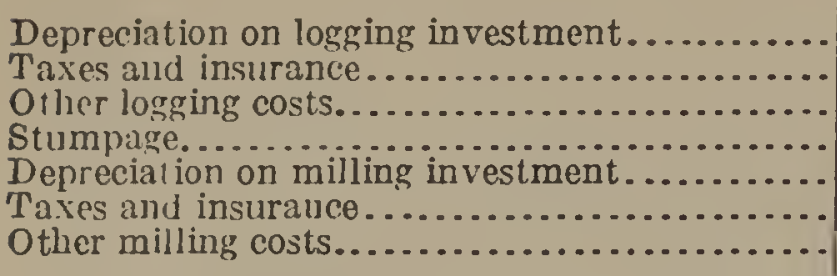 & $\begin{array}{r}\$ 0.34 \\
.09 \\
4.86 \\
1.75 \\
.39 \\
.16 \\
3.87\end{array}$ & $\begin{array}{r}\$ 0.09 \\
4.86 \\
1.75 \\
3.87 \\
3.16 \\
3.8\end{array}$ & $\begin{array}{l}2 \\
4 \\
4 \\
2 \\
6\end{array}$ & $\begin{array}{r}80.045 \\
1.215 \\
.437 \\
.08 \\
.08 \\
.645\end{array}$ \\
\hline Total......... & 11.46 & 10.73 & & 2.422 \\
\hline
\end{tabular}

The operation thus needs working capital equivalent to $\$ 2.422$ per thousand feet on its annual cut of $16,000,000$, log scale, a total of $\$ 38,752$. The average turn is approximately four and a half times a year, the working capital being about $22 \frac{1}{2}$ per cent of the sum of annual operating costs and stumpage payments, $\$ 171,680$.

If market and industrial conditions made it possible to turn the working capital used in logging every two months and the milling capital every month, tax and insurance expenditures still being turned twice annually, the calculation for the foregoing operation becomes as follows:

\begin{tabular}{|c|c|c|c|c|}
\hline Expenditure. & $\begin{array}{c}\text { A mount } \\
\text { per thousand } \\
\text { feet. }\end{array}$ & $\begin{array}{l}\text { Portion } \\
\text { paid from } \\
\text { working } \\
\text { capital. }\end{array}$ & $\begin{array}{l}\text { Number of } \\
\text { times work- } \\
\text { ing capital } \\
\text { is turned } \\
\text { annually. }\end{array}$ & $\begin{array}{l}\text { orking cap- } \\
\text { ital required } \\
\text { per thousand } \\
\text { feet } \\
\text { annually. }\end{array}$ \\
\hline 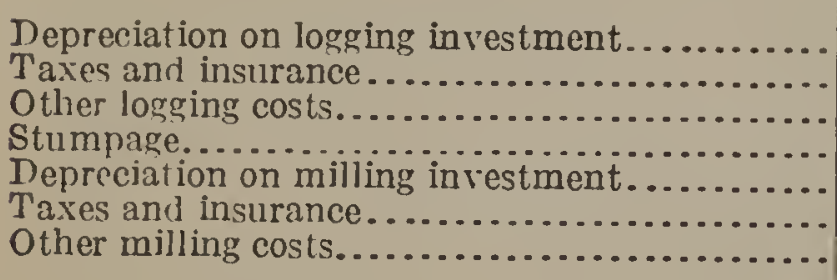 & $\begin{array}{r}\$ 0.34 \\
.09 \\
4.86 \\
1.75 \\
.39 \\
.16 \\
3.87\end{array}$ & $\begin{array}{r}\$ 0.09 \\
4.86 \\
1.75 \\
. .16 \\
3.87\end{array}$ & $\begin{array}{r}2 \\
2 \\
6 \\
6 \\
2 \\
12\end{array}$ & $\begin{array}{r}\$ 0.045 \\
.81 \\
.292 \\
. \\
.08 \\
.08 \\
.322\end{array}$ \\
\hline Total.. & 11.46 & 10.73 & . & 1.549 \\
\hline
\end{tabular}

Under these conditions a working capital of but $\$ 24,784$ is required to carry the same annual cut. The average turm is nearly seven times a year, and about 15 per cent of the sum of annual operating and stumpage costs is sufficient for working capital.

Margin for Contingencies.

Computations of working capital on the average turn are usually overconservative. A surplus must always be on hand to meet special demands, and the funds at work in the business can not always be expanded or contracted for short periods. A margin of 10 to 25 per cent should be added to the sum deduced as above to put the business on a practical working basis.

In Slow Operations.

In driving or other operations whose successive steps consume the greater part of a year the floating capital required usually ranges from one-half to three-fourths of the total yearly operating and stumpage costs. Instead of estimating the "turn" of the funds employed in each part of the operation the total working capital may conveniently be averaged for the year by tracing outgo and income as follows: 
In a cut of 20,000,000 feet annually it is assumed that stumpage payments, at $\$ 2.20$ per thousand, average as of January 1 ; that logging costs, at $\$ 4$ per thousand, average as of February 1; that driving costs, at $\$ 1$ per thousand, average as of May 1; and that milling costs, at $\$ 3.50^{\circ}$ per thousand, average as of July 1 . Sales at $\$ 15$ per thousand feet begin in August. The sale of 2,000,000 feet is credited to the lst of September and each of the succeeding nine months.

The working capital required to carry this business would then be:

\begin{tabular}{|c|c|c|c|}
\hline For- & $\begin{array}{l}\text { Balance } \\
\text { between } \\
\text { outgo and } \\
\text { income for } \\
\text { the ycar. }\end{array}$ & $\begin{array}{l}\text { Balanco } \\
\text { from } \\
\text { preceding } \\
\text { year. }\end{array}$ & $\begin{array}{l}\text { Working } \\
\text { capital for } \\
\text { the month. }\end{array}$ \\
\hline 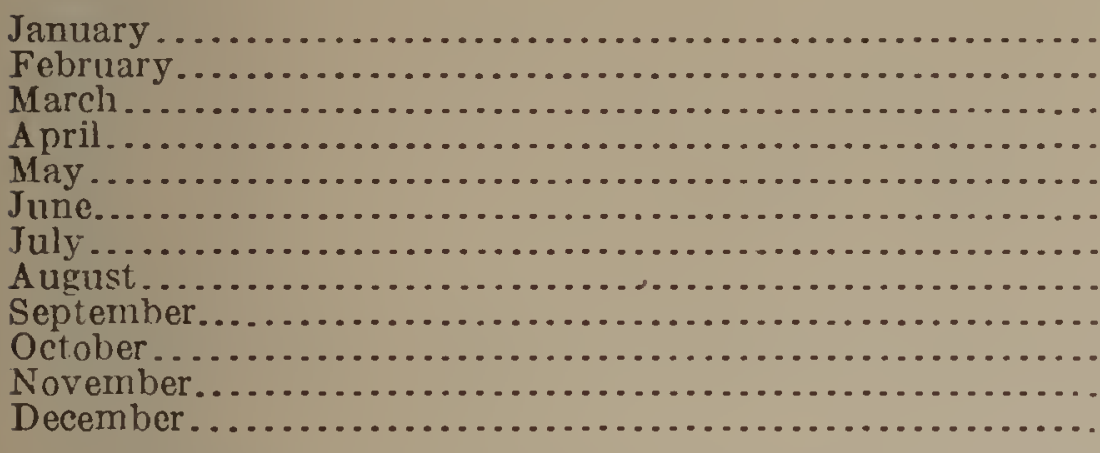 & $\begin{array}{l}\$ 44,000 \\
124,000 \\
124,000 \\
124,000 \\
144,000 \\
144,000 \\
214,000 \\
214,000 \\
181,000 \\
154,000 \\
124,000 \\
94,000\end{array}$ & $\begin{array}{r}+\$ 64,000 \\
+34,000 \\
+\quad 4,000 \\
\quad-26,000 \\
\quad-56,000 \\
\quad-86,000 \\
\cdots \\
\cdots\end{array}$ & $\begin{array}{r}\$ 108,000 \\
158,000 \\
128,000 \\
98,000 \\
88,000 \\
58,000 \\
214,000 \\
214,000 \\
184,000 \\
154,000 \\
124,000 \\
94,000\end{array}$ \\
\hline verage. & & & 135,167 \\
\hline
\end{tabular}

Or 63 per cent of the total annual producing cost of $\$ 214,000$. Ten or 15 per cent should be added to this total for safety.

The figures in the first column from January to August are the accrued costs of stumpage, logging, driving, and manufacture. The figures from September to December and in the second column from January to March, represent the accrued costs less sale receipts. The second column figures from April to June represent the surplus of sale receipts over accrued operating costs. The figures in the third column represent the capital required to carry current operating costs each month in the year.

Calculation of Working Capital from Average Stocks on Hand.

Another method of determining working capital, which is perhaps more direct and tangible than either of those discussed, is to foot up the average amount of advance stumpage payments, the value of the average stnck of logs and lumber, the average total of bills receivable which are carried for one month or more, and a reasonable cash balance. The value of $\log$ and lumber stocks should be calculated from current stumpage and operating costs. While the supply of logs and lumber varies to a greater or less degree, a fair average can usually be figured as constant in the business. This method furnishes an excellent check on computations of working capital from the average turn.

Use of Normal Rather than Speculative Stocks.

The quantity of lumber carried in the yards after manufacture should be estimated from the average yard stock under normal trade conditions, eliminating excess stocks carried for speculative reasons. Stocks carried over periods of depression to obtain normal prices may, however, be included.

Working Capital in Sales of Special Products.

In sales of tie or mining material, telephone poles, etc., the product is usually contracted to one buyer for payment on delivery. In driving or fluming operations deliveries are ordinarily made during a short period of the year and expenditures for stumpage and logging month by month must be carried until the date of delivery. The average working capital required may be estimated by computing the "turn" of each month's outlay, or the time which must elapse before cash returns are received. A 
simple method of obtaining this result is to set down each month's expenditure, multiply it by the number of months intervening until time of payment, and divide by 12 . To illustrate:

Logging in a small tie operation begins on the 1st of August and continues, including skidding and decking, until the 1st of April. The ties are flumed in June, and payment for the season's cut received in full by August 1. The working capital may be computed from the monthly expenditures as follows:

\begin{tabular}{|c|c|c|c|c|c|c|c|}
\hline $\begin{array}{l}\text { Date of } \\
\text { expenditure. }\end{array}$ & Amount. & $\begin{array}{l}\text { Months } \\
\text { until } \\
\text { payment. }\end{array}$ & $\begin{array}{l}\text { Amount } \\
\text { extended } \\
\text { for number } \\
\text { of months. }\end{array}$ & $\begin{array}{c}\text { Date of } \\
\text { expenditure. }\end{array}$ & Amount. & $\begin{array}{l}\text { Months } \\
\text { until } \\
\text { payment. }\end{array}$ & $\begin{array}{l}\text { Amount } \\
\text { extended } \\
\text { for number } \\
\text { of months. }\end{array}$ \\
\hline \multirow{2}{*}{$\begin{array}{l}\text { Sept. } 1 \ldots \ldots \ldots \\
\text { Oct. } 1 \ldots \ldots \ldots \\
\text { Nov. } 1 \ldots \ldots \\
\text { Dec. } 1 \ldots \ldots \ldots \\
\text { Jan. } 1 \ldots \ldots \ldots \\
\text { Feb. } 1 \ldots \ldots\end{array}$} & \multirow{2}{*}{$\begin{array}{r}\$ 2,000 \\
500 \\
500 \\
400 \\
1,000 \\
800\end{array}$} & \multirow{2}{*}{$\begin{array}{r}11 \\
10 \\
9 \\
8 \\
7 \\
6\end{array}$} & \multirow{2}{*}{$\begin{array}{r}\$ 22,000 \\
5,000 \\
4,500 \\
3,200 \\
7,000 \\
4,800\end{array}$} & \multirow{2}{*}{$\begin{array}{r}\text { Mar. } 1 \ldots \ldots \ldots \\
\text { Apr. } 1 \ldots \ldots \ldots \\
\text { July } 1 . \ldots . . . \\
\text { Total.... }\end{array}$} & $\begin{array}{r}\$ 1,200 \\
1,500 \\
900\end{array}$ & \multirow[t]{2}{*}{$\begin{array}{l}5 \\
4 \\
1\end{array}$} & $\begin{array}{r}\$ 6,000 \\
6,000 \\
900\end{array}$ \\
\hline & & & & & & & 59,400 \\
\hline
\end{tabular}

$\$ 59,400 \div-12=\$ 4,950$, the average amount of working capital required. (For a detailed illustration of the method, see p. 65.)

This method adapts itself to any special features in the expenditures of an operation, such as the purchase of supplies for an entire winter in advance, the payment of labor bills at the end of the logging season, etc. It is also readily applied in sales where payments for the product are distributed throughout the year, by estimating the number of months elapsing between the date of each expenditure and its return.

Such calculations should be based upon the terms and methods of payment for labor, supplies, etc., in common usage. As the standard practice, however, commissaries will not be considered in estimating working capital. Where board is furnished to laborers at a stated price or a general store is conducted in connection with a logging operation, it should be treated as a separate business enterprise not affecting the working funds required in the timber sale. If wages include board, the current cost of supplies and labor for the mess is a proper item of working capital. (See p. 13.)

Source of Overrun.

\section{OVERRUN.}

The Forest Service will follow the practice of lumbermen in prorating logging costs on log scale and milling costs on mill tally. These two standards seldom agree. The product of the mill ordinarily overruns log scale from 4 to 30 per cent, depending on the size, taper, and soundness of the timber, the thickness of saws and other matters of mill equipment, the exact dimensions to which lumber is sawed, and the class of material manufactured.

\section{A Necessary Factor in Stumpage Appraisals.}

The Forest Service does not guarantee an overrun. It is, however, too large a factor to be ignored in accurate stumpage appraisals. In many operations overrun alone furnishes a fair profit. If equivalent to 20 per cent or more of the log scale, it may easily increase profits from 60 to 100 per cent. Nor should overrun be dismissed as no more than an offset to business hazards such as car shortage, fire losses, labor troubles, and the like. Accurate appraisals must take into account all of the actual costs which can be forseen and all anticipated returns, one of which is overrun. Hazards which enter into the risk of the operation but do not justify specific cost items should be given full weight in the margin allowed for profit.

\section{Determination of Overrun.}

The appraiser should ascertain from mill records or special mill-tally checks against log scale what overrun may be expected under Service scaling in the particular class of timber concerned. Any percentage used must be conservative, particularly until 
exact checks upon the Service scale in the same class of timber have been obtained. Overrun at the saw is not a safe criterion. It is important to allow for losses in finishing and seasoning, which often reduce materially the gain at the saw. Reduction in grade during seasoning will be taken into account in determining average selling prices. (See below.) Losses in quantity between sawing and shipping should be considered in fixing the percentage of overrun. Overrun figures once obtained can well be standardized for each species, by size and soundness of logs, over large regions. Separate standards should be established for small circular mills and well-equipped band mills. The standard overrun then used in each appraisal will depend upon the size of the chance and the type of mill adapted to handle it. Any further refinement based upon the equipment of mills is ordinarily unnecessary.

Log Scale the Final Basis in Calculations.

In their final form, all factors in the appraisal will be reduced to log scale. Depreciation and logging costs be computed directly on log scale. By use of the ascertained per cent of overrun, milling costs and selling prices will be extended to the log-scale basis. This can be done by multiplying the milling cost and selling price per thousand feet of lumber by 1 plus the per cent of overrun. The final computations of profit and stumpage price will then be on log scale. The following example will illustrate the method:

Let it be assumed that logging costs $\$ 4$ per thousand feet log scale and depreciation $\$ 1$; that milling costs $\$ 5$ per thousand feet of lumber; that the average selling price is $\$ 15$ per thousand feet of lumber; and that the overrun is 15 per cent. Then:

Logging $1 \mathrm{M} \log$ scale.................................... $\$ 4.00$

Depreciation on $1 \mathrm{M} \log$ scale................................ 1.00

Milling 1,150 feet of lumber ( $1 \mathrm{M} \log$ scale) at $\$ 5$ per $\mathrm{M} \ldots \ldots \ldots \ldots \ldots \ldots \ldots . \ldots \ldots$

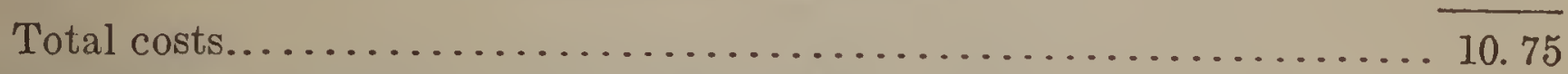

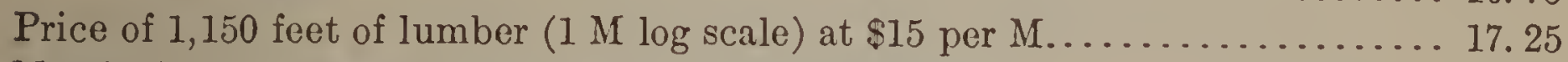

Margin for stumpage price and profit per $M \log$ scale................ 6.50

\section{LUMBER AND LOG SELLING PRICES.}

Appraisals Based Upon Lumber Selling Prices.

Appraisals of saw timber on the National Forests will be based upon the selling prices of lumber manufactured in the same region from stumpage of similar quality. The determination of the lumber selling prices applicable to the chance is thus one of the most important duties of the appraiser.

\section{Average Selling Price of Various Grades.}

The problem is comparatively simple where lumber of but one grade is manufactured. In all but the smaller operations, however, lumber is graded and sold at grade prices which cover a wide range in value. The problem is further complicated by varying prices for different dimensions. The average selling price of the product in such cases depends not only upon the price obtained for each grade, but upon the proportion of the different grades in the standing timber. To ascertain this proportion, a careful examination of the timber is necessary, checked wherever possible by the cut of grades obtained in manufacturing similar stumpage at local mills. The proportion of grades taken should be at the time of sale, not at the saw, thus allowing for deterioration during planing, seasoning, and carrying in the yard.

Form of Calculating the Average Price.

Wherever possible, the estimated proportion of grades with the market price of each should be given in the following form. If this is not practicable, an average price for the species in which the various lumber grades have been taken into account may be reported.

$60813-14-3$ 
Estimated per cent of grades with average grade prices for western yellow pine.

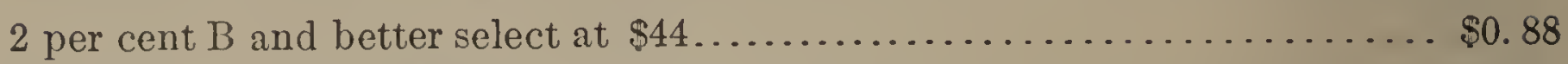

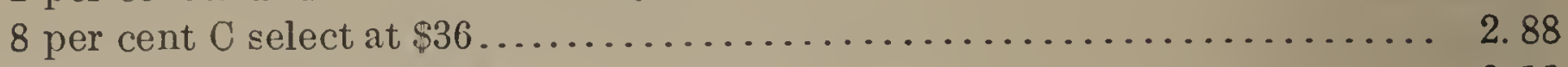

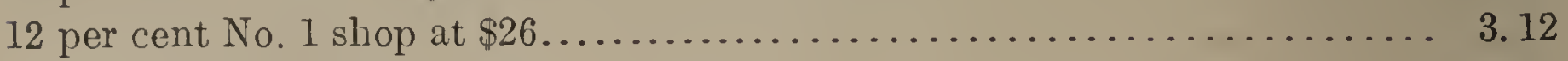

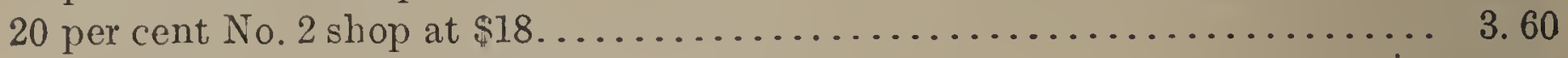

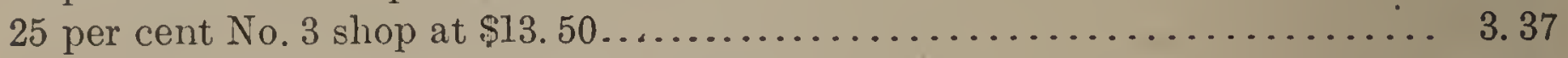

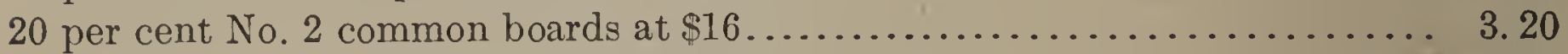

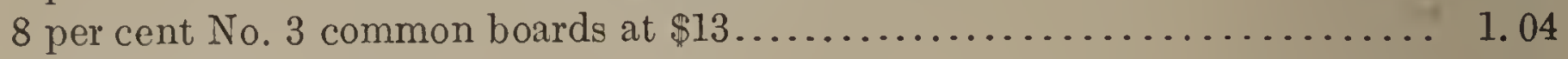

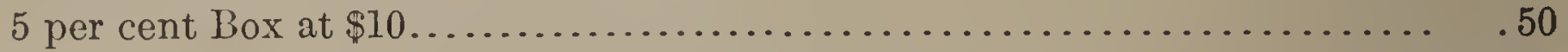

100 per cent. A verage...................................... 59

Average Selling Price of Mixed Stands.

If necessary to obtain the average lumber selling price of all of the stumpage in mixed stands, a similar calculation may be made by species, as follows:

\begin{tabular}{|c|c|c|c|}
\hline $\begin{array}{l}\text { Per } \\
\text { cent. }\end{array}$ & Species. & $\begin{array}{l}\text { Average } \\
\text { selling price } \\
\text { of species. }\end{array}$ & $\begin{array}{l}\text { Weight in } \\
\text { arerage price } \\
\text { for the chance. }\end{array}$ \\
\hline 30 & \multirow{8}{*}{ 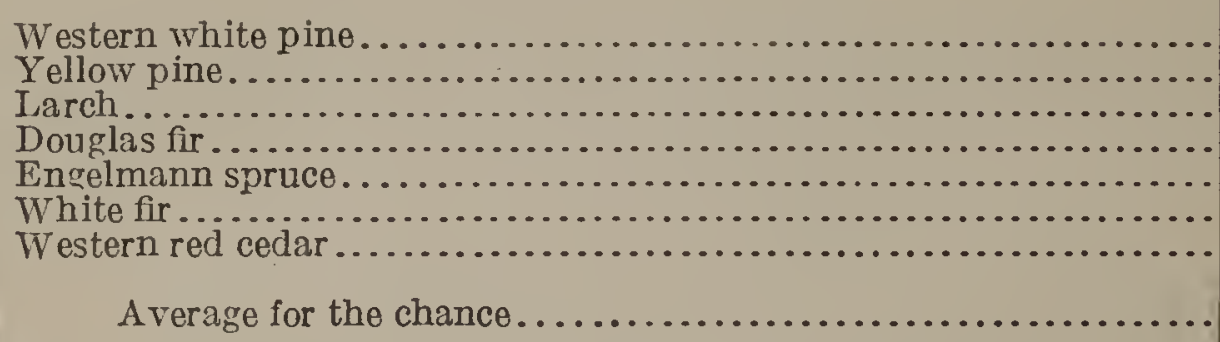 } & \multirow{8}{*}{$\begin{array}{r}\$ 21.00 \\
17.00 \\
13.00 \\
13.00 \\
15.00 \\
12.50 \\
12.00\end{array}$} & $\$ 6.30$ \\
\hline 5 & & & .85 \\
\hline 12 & & & 1.56 \\
\hline 18 & & & 2.34 \\
\hline 3 & & & \\
\hline 25 & & & 3.125 \\
\hline 7 & & & .84 \\
\hline 100 & & & 15.465 \\
\hline
\end{tabular}

Lumber Prices Prevailing in Producing Regions.

The effort should be to obtain average lumber prices, by grades, holding for the producing region, or manufacturing district in which the chance is located. Such a region ordinarily includes all the mills (1) manufacturing timber of similar species and generally similar quality, and (2) subject to the same market conditions as represented by freight rates to main consuming points and competition with other manufacturing districts. The more mills from which price data are obtained the better. The aim will be to obtain grade prices or prices by species which are general averages rather than individual rates applicable to a single mill.

\section{Lumber Prices During Normal Market Conditions.}

Lumber prices holding for brief periods are not reliable. If obtained during a year of depression or temporary inflation they are unfair either to the Government or the operator. As far as practicable, the prices used should represent normal conditions in the lumber market. This can be done most practicably by averaging the prices received during a period of two years, or even longer if repeated fluctuations have occurred. As a general rule no prices should be used which do not represent the average lumber market during at least one year.

The appraiser should furthermore study the data on prices for as long a period as authentic records are available and ascertain as far as he can the broad market tendencies indicated. If a straight average does not meet his judgment of a normal price in line with the movements of the market, he should recommend other rates which in his belief should be used.

\section{State of Manufacture and Shipment.}

Prices should be taken as a rule on lumber ready for shipment, commonly f. o. b. cars at the mill or nearest common carrier shipping point. In the case of plants which finish a portion of their product, the prices of the respective grades in the proportion and state of finish at which they are shipped may be used. Intensive forms of manu- 
facture, as boxes, sash and door, etc., should be disregarded and prices reckoned on the lumber itself, preferably in rough form, at the most convenient point in the whole process. Lumber freights over common-carrier roads should be eliminated from price and cost estimates as far as practicable. Net returns at the mill or its nearest commoncarrier shipping point is the standard basis for appraisals.

\section{Value of By-products.}

The sale value of lath, slabwood, and other by-products which are usually manufactured and have an established market should be taken into account in computing the total return for each thousand feet, log scale. This may be done by adding the milling cost on such products per thousand feet log scale to the other milling charges and similarly their sale value to the lumber selling price computed on log scale. The same result will be closely approximated by adding the profit on by-products per M feet log scale to the average lumber selling price.

\section{Prices of Other Products than Lumber.}

When timber is sold as railroad ties, shingles, telephone poles, etc., the selling prices of these products as they pass from the hands of the purchaser will be ascertained and used in the calculation in the same manner as the selling price of lumber. Where products like cedar poles are handled by distributors, without manufacture, f. o. b. prices at main shipping points will be the ordinary basis taken.

\section{Use of Log Prices as a Check.}

The price of saw logs will not be used, however, as a basis for stumpage appraisals. For this purpose the lumber market is taken by the Service as determining the value of saw timber. In sales to loggers appraisals should be based on lumber selling prices and all costs from stump to market reckoned as in sales to purchasers who operate mills. Log prices, however, serve as an excellent check in such sales. They should be ascertained and considered by the appraiser in fixing the price of the stumpage. The report should indicate how far it will be practicable for loggers to purchase stumpage on a lumber market appraisal and what prices would be equitable if the log narket were the basis taken.

\section{What Profit is.}

\section{PROFIT.}

Profit is the amount which may be taken out of the business over and above depreciation charges, while still leaving its working capital intact. It is usually figured as a percentage, returned each year, of the total investment in the enterprise. It is most clearly represented, however, by a sum per thousand feet or a total sum on the year's cut. 'The cash balance at the end of a year's operation consists of three parts: (1) an amount set aside for depreciation, which pays back some portion of the original investment, (2) working capital, or the portion of it available as money, and (3) profit, or the surplus over the other two sums.

The preliminary work in stumpage appraisals results in two figures: (1) the sum of operating cost, and depreciation of fixed investments, and (2) the average seling price of the product. The difference between the two is made up of profit and stimpare price. The final problem is to divide this amount fairly hetween profit and sturnpage.

\section{Profit Margin in Stumpage Appraisals.}

No profit is guaranteed by the lorest Service. It is necessary, therefore. not only to appraise on the basis of a fair net return to the operator. but to include an additional amount to protect the net profit and insure its realization. What the appraiser really estimates, therefore, is a profit margin made up of these two parts.

An equitable profit, or profit margin, based upon ordinary management and average luck, is essential in every stumpage appraisal. Its aim will be, however, to insure a fair industrial return to the operator, proportioned to the risks and commercial standing of the business, not the speculative or unearned reward of the shrewd investor. 


\section{Elements in Profit.}

Profit in timber operations involves three general elements: (1) interest on capital invested, (2) reward for the personal energy and ability of the operator, and (3) allowance for risks to which the business is subject.

\section{Interest on Investment.}

Interest on invested capital at prevailing commercial rates is often treated as a cost rather than profit. It is, however, a return from the operation, and in National Forest appraisals will be classed with other returns as an element of profit.

Capital industrially emploved in National Forest operations is entitled to a return on its own account, regardless of any other elements of profit, of at least 6 per cent. In nearly all business return on invested capital is the most clearly established and controlling basis of profit. This is particularly true of the larger and more permanent enterprises whose processes are standardized and whose organization is developed along permanent and stable lines.

\section{Reward for Personal Effort.}

The second element, reward for personal initative and capacity, is much more variable. In large operations, business ability and skillful management are in the main furnisher by employees, paid by salaries, and accounted for in costs of production. The personal element does not enter largely into profit, although usually evident in the organization and beginning of an enterprise and not infrequently recognized in going operations by stock bonuses or profit sharing. It is of special importance in lumbering as compared with other industries on account of the lack of standardized processes and the knowledge of many different commercial and technical branch es which is required.

In the smaller enterprises, of a more temporary character and less stable organization: individual energy and initiative are much more important factors in the conduct of the business. The capital invested is often relatively small and profit mas be largely a reward for personal effort.

The weight to be given this element in Forest Service appraisals will necessarily vary in accordance with the character of the chance. It will be greater in small, short-lived operations than in large sales of long duration. It should be slight in appraisals of timber available to well-established, going plants. On the other hand, it inust be relatively great in the case of new enterprises with an organization to create and markcts to develop, particularly if special conditions must be met which require exceptional experience, business capacity, or other personal qualifications on the part of the buyer.

\section{Business Risks.}

The third element of profit, a return covering business risks, is required in lumbering to a greater degree than in most other industries. This risk consists (1) in the double chance of a decline in the lumber market and an increase in operating costs, which the course of lumbering history shows to be great, and (2) in possible losses and accidents which are inherent in a business dealing with rugged physical conditions, but can not be accurately foreseen or reckoned in cost estimates. While the physical risk to investments beyond the limits of insurance are not ordinarily great, serious business losses are usually involved in their destruction or injury. The destruction of a sawmill by fire, for example, involves not only the loss of the value of the plant not covered by insurance, but also loss of custom, loss of operative force, and loss of profit through reduction in output.

Particular chances are often subject to special risks. 'These directly aifect their value and must be taken into account in appraisals by giving proper weight to the risk element in profit. A stream may be of such a nature as to endanger either hanging up drives indefinitely or carrying them through storage booms. Small streans which 
have never been driven are usually uncertain and risky features of a chance. Similarly the necessary location of a road, flume, or railway may subject the operation to special risk on account of frequent washouts.

\section{Risk on Fixed Investments and Working Capital.}

Risk is ordinarily much less on working capital than on fixed investments. The latter are not merely liable to physical damage, but become a total or partial loss if the enterprise fails. In a peculiar way, therefore, they are involved in the hazards of the business. Working capital, which is represented at any given time by logs, lumber, bank account and bills receivable, is subject to loss or reduction, but is not so involved in the success of the enterprise. In case of failure, lumber and log stocks can usually be realized on and outstanding accounts collected. Hence a smaller rate of profit is sometimes figured in business practice upon working capital than upon fixed investments. The relative amount of the two may legitimately influence the general profit rate.

\section{Other Factors Afrecting Risk.}

In the consideration of timber chances, operators must also take into account possible overestimates of the quality of the stumpage or the selling price of the various lumber grades and possible underestimates of necessary investments or operating costs. The size and permanency of the operation are important factors. Large investments carried for long periods, like railroads and modern office buildings, are satisfied with a lower return than smaller, less stable enterprises. Operators with established markets and transportation facilities will accept a lower return than where these features of the business must be constructed or developed. All of these are factors of risk which must be weighed by the appraiser in determining the profit margin which should be allowed.

\section{Comparison with Other Kinds of Business.}

The lumber business involves greater risk and uncertainty than most manufacturing enterprises. Industries characterized by permanence and physical safety of investments, standardized processes and assured markets are run on a margin of profit which would be wholly inadequate for lumbering. Its general conditions are entirely different. Each operation must be adapted to the topography of its chance. New methods must often be developed and applied to peculiar local conditions. Exactness in estimates of investments and operating costs is practically impossible.

The capital invested in fixed improvements is subject by their nature and location to a great fire risk which can not be as fully insured against as in most comparable lines of business. The work is hazardous and injuries to workmen are frequent. The hazard from unusual climatic conditions is greater than in most manufacturing industries. Losses due to uncontrollable causes, such as car shortage and bad accounts, are common. As in other enterprises, the business is subject to labor troubles and breakdowns. It is dependent upon unskilled labor to an exceptional degree. All of these tend to make a high profit margin necessary.

\section{Comparison with Private Operations.}

Operations on National Forests have certain financial advantages when compared with private lumbering. The system of small payments amounts in long-time sales to a substantial saving of interest and taxes. The effect of this, however, is upon cost of production, not upon certainty of profit.

Operators in National Forests, however, have some advantages over private lumbermen in the matter of risk. Owning no timber, they have a smaller total investment, and consequently less to lose if the enterprise is a failure. Since title to the timber does not pass until it is cut and scaled, they run much less risk of loss frem fire. 
On the other hand, contracting to log under Government supervision necessarily involves a risk, however small, which the operator on private land avoids. Furthermore, the purchaser of National Forest timber foregoes to a large extent speculative profits from increased stumpage and lumber values and from overrun, both in estimate and scale.

\section{METHODS OF RECKONING PROFIT.}

Investment Method.

A percentage return on the capital invested, covering all of the elements discussed above, is the clearest and most satisfactory means of reckoning the profit margin. It accords with the usual business practice and conceptions and permits ready comparison with other industries. This method of reckoning profit, known as the "investment method," will be standard in the Forest Service. It should be employed uniformly in appraising the larger chances, and in appraising the smaller bodies of timber wherever it is applicable.

\section{Compensation for Personal Services.}

The investment method is seldom adapted to the smaller and shorter-lived operations. The capital required in such cases, as a rule, is relatively little and inadequate as a basis for reckoning profit. Supervisory charges are usually not covered in operating costs. The energy and ability of the purchaser are the main factors upon which the enterprise is conducted. Similar conditions often apply to operations cutting special products like railroad ties or mining timbers, which require comparatively little capital.

The profit margin may be reckoned in such cases partly as a return on money invested and partly as pay for the operator's time and enterprise.

Profit is thus split up into the elements discussed above and a return provided for each in its own terms. A fair percentage, taking as a rule the same rate used in the investment method, should be allowed on such capital as may be required for improveinents or working funds. This covers interest and risk on money invested. At the aame time, the element of personal services is covered by a salary per year or month adequate for the management and direction of the business. The latter is in effect a clarge for supervision, but is fixed directly in accordance with the demands of the business upon the personal time of the operator. This method will be used ordinarily where the investment method is inapplicable.

\section{Overturn Method.}

Another method of reckoning profit is to take a percentage of the total operating cost and depreciation, or "overturn." This should be used only in cases where the investment is very small in comparison with current operating costs or is difficult to estimate, and hence affords an insufficient basis for determining profit. The method is used largely in railroad work and general contracting. If the sum of depreciation and cperating costs, for example, is $\$ 12$ per thousand feet, the profit may be figured as 20 per cent ci that amount, or $\$ 2.40$.

The overturn method is of special value in small sales where the investment is negligible or where operating costs can be closely estimated but the capital required is uncertain or difficult to determine. Operating costs, which make up most of the overturn, are usually ascertained more readily than investments. The overturn method is thus safer for appraisers who are not expert in calculating the investment features of lumbering operations. It may also be used if desired in arriving at the profit due on logging as distinct from manufacturing where it is necessary to deal separately with the two parts of the operation. (See p. 43.) 


\section{Checks on Profit Calculations.}

The rates of profit given in these instructions are necessarily tentative. Final rates can be established only by experience in studying and analyzing actual returns from many different operations. It is therefore essential to check calculations of profit by direct operating standards as far as they can be obtained.

\section{By Going Operations.}

Systematic study of the profit obtained in going sales and private operations is a valuable and necessary check upon this feature of stumpage appraisals. To permit direct comparison, it should be computed in terms of per cent on investment, per cent on overturn, etc., conforming with the methods prescribed in these instructions. A frequent check of the results of former appraisals to ascertain what rates of profit are sufficient and equitable under the particular local conditions is one of the most essential parts of the appiaiser's work.

\section{By Current Bids.}

The profit margin indicated by current or past bids for National Forest clances in the same region, as showing the basis upon which operators are willing to buy stumpage, shculd be used to clieck appraisals under either the investment or overturn method. As the lumbering industry develops in new regions and becomes more stable, operators are willing to purchase at lower profits. This is shown by the course of stumpage values in the older manufacturing regions. The prices bid in current sales thus form the best index to the rate of profit required by the local lumbering industry.

\section{By Money Profit Per Thousand Feet.}

The profit reckoned in the appraisal may be checked also as a sum in dollars and cents per thousand board feet or other unit of output. A stated profit per thousand feet is a direct and tangible figure, widely employed in the lumber business. As experience is gained, it is probable that more definite standards of profit in money per thousand feet can be established for operations of varying size and kind of output under each of the more common sets of local conditions with respect to markets, logging risks, etc. Such standards will greatly facilitate uniform appraisals. A check of the results obtained by any method of reckoning profit, from this standpoint, is therefore desirable.

A profit margin of from $\$ 1.50$ to $\$ 4$ per thousand feet appears to cover what is legitimate and necessary in practically all classes of sales which involve botlı logging and manufacture. The smaller amount may be sufficient for established operations of considerable size where logging and market conditions are well known, methods fully developed, and no extraordinary investment or risk is involved. The larger sum may be necessary in small and irregular operations and those involving exceptional investments, special difficulties in marketing the product, or unusual risks. Under average conditions of investment and risk a profit margin of $\$ 2$ to $\$ 3$ per thousand feet is adequate. As the lumbering industry becomes developed and settled in any region a number of factors, such as lower interest rates on borrowed money, better understood logging conditions, standardized methods of manufacture, and more stable markets, tend to reduce the profit expected.

\section{Check on Profits in Sinall Sales.}

The main factors to be taken into account in checking the profit per unit $f$ cut are relative investment, relative risk, and amount of output. The following table will serve as a guide in checking the profit margin obtained in small sales under different sets of conditions. ${ }^{1}$ Higher profits are set down for the smaller operations because

1 This table is based upon profits obtained in current sales which are apparently satisfactory, not upon mathematical calculations. 
(1) their organization and methods are not so well standardized, and (2) the risk, return on money invested, and payment for the personal services of the operator must be borne by a smaller output.

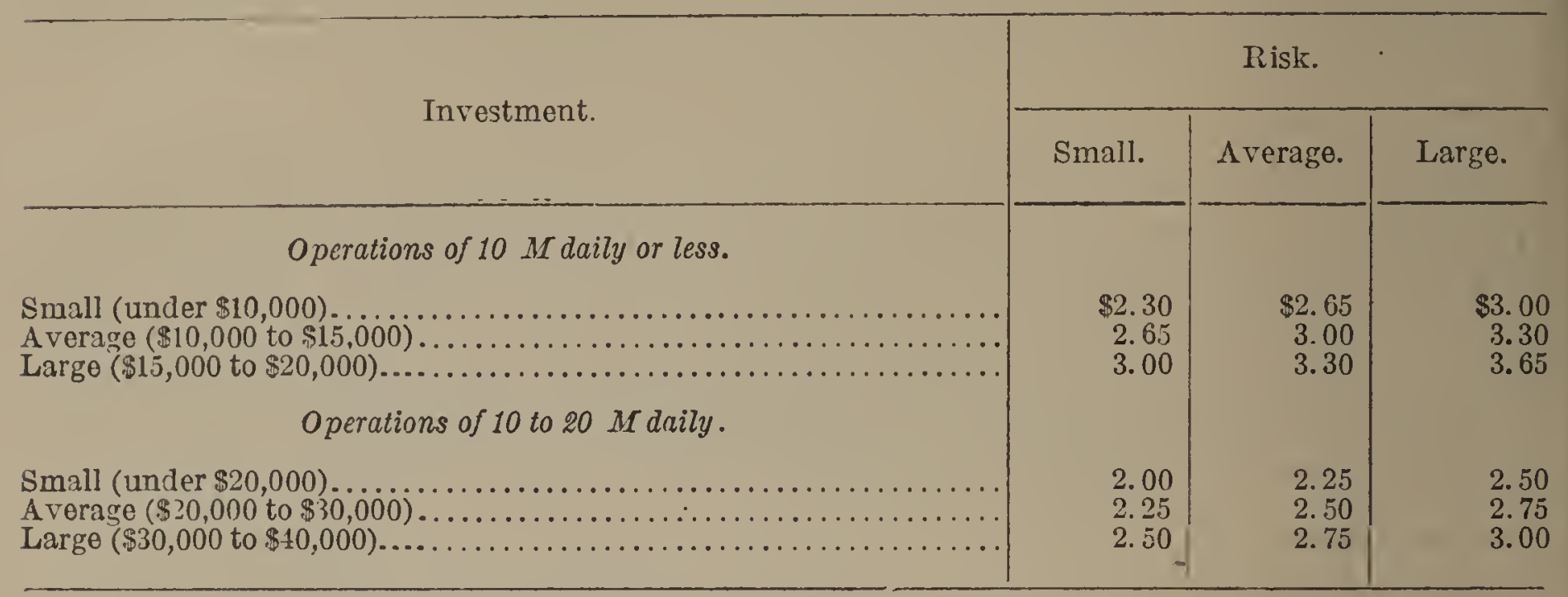

\section{Application of the Investment Method.}

Profit calculated as a percentage of the money in the business should strictly be proportioned each year to the capital invested in the operation during that period. For simplicity, however, the average investment during the life of the sale may be taken. This is not mathematically exact as to the actual amount invested during any given year, but is a fair basis for calculating profit during the operation as a whole.

\section{Frequency of Turn Not Considered.}

As indicated on page 29 , the frequency of the turn has an important bearing upon the amount of working capital required in the business. The average annual investment once determined, however, the frequency of the turn does not affect the calculation of profit. The average investment is conceived as a certain sum set aside in the operation and earning annually a specified percentage of itself, whether the overturn is once a month or once a year.

\section{Calculation Under Investment Method.}

The application of the investment method is simple. The average amount of money employed in the operation, including working capital and fixed investments, must be determined. Fixed investments may be averaged as indicated on pages 19 to 24 . Working capital can usually be computed as a constant amount throughout the operation. A specified percentage of this figure gives an annual sum which must be set aside as the profit margin. This sum divided by the yearly cut gives the profit per thousand board feet. The sum of profit and depreciation per thousand feet and current logging and milling costs deducted from the selling price gives the stumpage rate at which the timber should be appraised. Expressed as a formula, the calculation becomes:

$$
X=S-\left(L c+M c+D+\frac{\text { per cent of }(A+W)}{\text { cut }}\right.
$$

$X$ represents the stumpage price, $S$ the average selling price, $L c$ the logoing costs, $M c$ the manufacturing costs, $D$ the depreciation of fixed investments, $A$ the average fixed investment in the operation, and $W$ the working capital, all as amounts per thousand feet log scale. To illustrate:

In an operation cutting 10,000,000 feet annually the estimated average investment including working capital is $\$ 235,000$ and the annual depreciation $\$ 12,000$. Logging costs $\$ 6$ per thousand feet $\log$ scale and milling $\$ 4.50$ per thousand feet, lumber 
tally. The overrun for the class of logs involved, yellow pine rumning 10 logs per thousand feet, is 20 per cent; and the average selling price mill run, lumber tally, is \$16. The operation involves comparatively low risks, the timber being cut by an established mill with well-developed markets. A return of 15 per cent on the investment is deemed equitable. The elements in the formula are thus:

Selling price $(1,200$ feet at $\$ 16$ per $\mathrm{M}) \ldots \ldots \ldots \ldots \ldots \ldots \ldots \ldots \ldots \ldots \ldots \ldots \ldots \ldots \ldots \ldots$

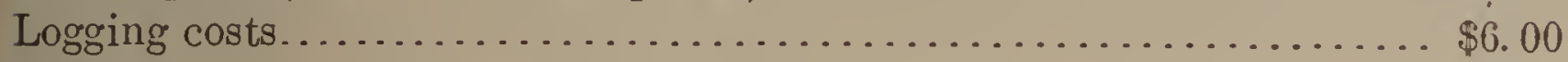

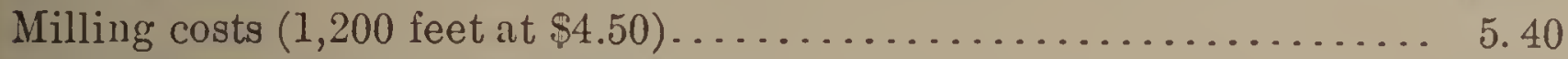

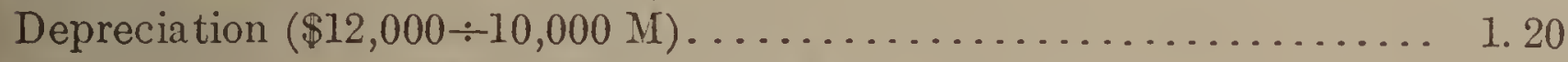

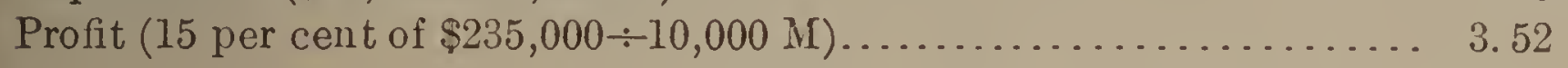

Total charges................................. 16.12

Stumpage price........................... 3.08

Rates of Profit Under Investment Method.

For a lumbering operation of good size, extending over a period commensurate with the life of the plant, 15 to 20 per cent on money invested is a fair margin for profit. On chances tributary to established plants which are in a position to purchase them, in regions where logging involves no extraordinary problems or unusual risks and where manufacturing conditions and markets are well developed, 15 per cent should be the general standard. If new plants must be constructed and business enterprises developed, other conditions being substantially as above, the profit margin may properly be extended to 18 or 20 per cent. If exceptionally large investments must be made to open up new country, or the industry developed largely under new conditions, or if special risks like uncertain streams or extremely variable markets must be encountered, a profit margin of 22 to 25 per cent is equitable. Twenty-five per cent is the general standard in small sales where a return on the investment is combined with payment for personal services.

Different Rates on Different Parts of the Investment.

As indicated on page 37, the risk to which different parts of the investment in a lumbering operation are subject may vary within considerable limits. Practically no risk, for instance, attaches to investments in land for mill sites. Working capital is normally subject to less risk than fixed investments.

Investments in main line railroads which will be maintained as common carriers after the chance is logged out differ from other fixed investments both in risk and permanence.

A lower rate of profit, usually 10 or 12 per cent, should be allowed on railroads for which permanent traflic is anticipated. Otherwise no distinction will be made in the returns figured on the various parts of the total investment required. The differences in risk of mill-site investments, working capital, woods improvements, etc., and the proportion of each in the total should be considered, however, in choosing an average profit rate for the whole.

\section{Interest on Borrowed Capilal.}

It should be noted that these profit margins include whatever interest is payable on borrowed capital. No distinction will be drawn between bonds, notes, or other loans and capital stock or other funds advanced directly by the operator. Out of the profits earned, however, must be taken whatever is required to carry the indebtedness of the concern. Most operators after paying their annual interest charges from the proceeds of the business enter the remainder as profit earned by their own capital. In Service appraisals which treat borrowed and unborrowed funds alike the profit margin 
includes any such carrying charges on part of the capital as well as the net returns, averaged for all the money used in the business. Exceptionally high interest rates on bonds or notes is thus a factor which should be considered in fixing the profit margin.

Application of Return for Personal Services.

If the capital invested is inadequate as a basis for determining profit, it may be supplemented by a return for personal services. This method is especially applicable in small sales, which require but limited investments and depend primarily upon the personal energy and effort of the operator. Such capital as is required should return a percentage equivalent to that customarily figured for large sales in the same locality. Twenty-five per cent is a fair average figure. In addition, the appraisal should include, as a charge for superintendence, a salary of $\$ 100$ to $\$ 200$ per month, depending upon the size of the operation, as compensation for the foremanship or personal effort of the purchaser.

This method will be used ordinarily when the investment method is inapplicable.

Application of the Overturn Method.

Profit under this method is a percentage of the overtum, or the entire production cost of a thousand feet of timber at the date of sale, including operating charges and depreciation, but not stumpage price. The calculation may be expressed by the following formula:

or transposing

$$
\begin{gathered}
X=S-(L c+M c+D)-\text { per cent of }(L c+M c+D) \\
X=S-(1+\text { per cent }) \text { times }(L c+M c+D) .
\end{gathered}
$$

$L c, M c$, and $D$ represent logging costs, milling costs, and depreciation, all in amounts per thousand board feet $\log$ scale. $X$ is the stumpage price and $S$ the average selling price log scale. Per cent represents the rate of profit allowed on the overturn.

Taking the operation used to illus trate the investment method, page 41, the following result is obtained from the formula:

Depreciation is $\$ 1.20$ as before, logging costs $\$ 6$, milling costs $\$ 5.40$, and selling price $\$ 19.20$, all in terms of $\log$ scale. If 25 per cent on the overturn be regarded as a fair profit, the calculation becomes:

$$
\begin{aligned}
& X=\$ 19.20-\$ 1.25(\$ 6+\$ 5.40+\$ 1.20) \\
& X=\$ 19.20-\$ 15.75, \text { or } \$ 3.45 .
\end{aligned}
$$

It should be noted that the profit margin in this calculation is $\$ 3.15$, as compared with $\$ 3.52$ under the investment method with a rate of but 15 per cent. The factors affecting comparative results under the two methods are discussed on page 43 .

\section{Relation to Fixed Investments.}

It is apparent that fixed investments are included in this calculation of profit only to the extent of their annual depreciation. The residual portion of the fixed investment or wrecking value at the end of the operation is given no place in the determination of profit. As a rule, depreciation of fixed investments forms 10 per cent or less of the total cost of production on which profit is figured. Profit by this method is thus related primarily to operating costs-that is, to the overturn of working capital.

\section{Bearing of Frequency of the Turn on Profit.}

Under the overturn method, the profit allowed, except the small part based upon depreciation, is realized every time the working capital expended in operating costs is turned. The frequency of the turn thus has an important bearing upon the total profits of the year earned by the working capital in the business. In the illustration cited on page 42 , for example, the profit margin on each thousand feet manufactured 
is $\$ 3.15$. The part of this earned by working capital, excluding depreciation of fixed investments, is $\$ 2.85$. If the turn is but once a year, this profit would be earned by $\$ 11.40$ of working capital, an interest rate of 25 per cent. If working capital is turned twice a year, the same profit would be earned by $\$ 5.70$, an interest rate of 50 per cent. If the working capital is turned every three months, or four times annually, the money actually used in the business in this form would be earning 100 per cent yearly.

Divergent returns on money invested are thus obtained under the overturn method unless the per cent of profit is carefully adjusted to the frequency of the turn. With more frequent turns, lower rates should be used.

From the foreging it is clear that the overtum method is not adapted to appraisals made primarily from the standpoint of capital invested. The investment method should be used invariably under such conditions. The profit margin should be based on overturn only when the investment is too limited for this purpose, and it is more practicable to arrive at the profit on a simple basis of contract work, disregarding investment considerations altogether.

Profit may thus be based upon the orerturn in small operations whose make-up is such that the investment method combined with a return for personal services is not applicable; and in larger operations which require comparatively little capital, like many sales of tie, pole, or mining timber, where the overturn may be the most practicable means of determining a fair profit margin proportioned to the character and risks of each chance.

\section{Different Rates on Logging and Milling.}

A modification of the overturn method may be used in localities where it is desirable to treat logging and manufacturing as distinct operations, each earning a profit adjusted to its peculiar conditions and risks. In established manufacturing regions, milling is the more stable part of the business. Methods and costs are more uniform than in logging, both in the same mill from year to year and in different mills cutting the same class of timber. Risks are usually less variable than in woods operations. Logging, on the other hand, may be subject to varying combinations of topography, climate, accessibility, certain or uncertain log transportation, and the like. The range in logging costs and investments and in logging hazards may thus be much greater than in the case of milling. When such conditions exist, particularly in localities where sales are made to established mills, it may be desirable to use a uniform rate of profit on the overturn in milling, including depreciation of mill investments. This rate should be fixed in accordance with local manufacturing standards and particularly the frequency of the turn of working capital. Under average conditions, with working capital turned three or four times a year, a profit of 15 per cent on the milling overturn is sufficient. The profit on the overturn in logging, including depreciation of logging investments, may then be adjusted to the conditions and risks on each chance.

This application of the overturn method may be illustrated by the operation previously cited, page 41 . Of the total investment required, $\$ 85,000$ is used in milling and $\$ 150,000$ in logging. Depreciation is similarly divided, $\$ 3,000$ on the mill investment and $\$ 9,000$ on the logging investment, the latter including the logging railroad and rolling stock. Fifteen per cent profit, the standard for the region, will be allowed on the milling overturn and 25 per cent on the logging overturn, the chance involving average hazards.

The formula is as follows:

$$
X=S-(L c+L D+\text { per cent }[L c+L D])-(M c+M D+\text { per cent }[M c+M D])
$$

That is, the stumpage price is the selling price less the sum of logging costs, depreciation on logging investments and logging profit, which is a per cent of logging costs and depreciation; less also the sum of milling costs, depreciation on mill investments, and the milling profit, which is a per cent of milling c osts and depreciation. 
Using the data from the operation cited,

$$
\begin{aligned}
& X=\$ 19.20-(\$ 6+\$ 0.90+.25[\$ 6+.90])-(\$ 5.40+.30+.15[\$ 5+.30]) \\
& X=\$ 19.20-\$ 6.90-.25(6.90)-\$ 6.55 . \\
& X=\$ 4.03, \text { the stumpage price. }
\end{aligned}
$$

The profit on logging and manufacturing may also be calculated separately by using the overturn method for the former and the investment method for the latter. This use of the two methods is adapted to the usual conditions in the industry where logging and milling are conducted by separate business organizations. Manufacturing operations represent the larger investments and their profit can be determined best as a return on investment. Logging jobbers, however, who supply the mills with timber require comparatively little capital. Personal ability and effort are as a rule the main factors in their business. Their profit may thus be satisfactorily determined (1) by the overturn method, or (2) by payment for personal services with a percentage return on such capital as their logging business may require.

While a distinction is recognized in calculations of this character between logging and milling, the stumpage price should always be obtained from the selling price of lumber, not the selling price of logs. (For a further discussion of this point see p. 35.)

\section{Rates of Profit Under Overturn Method.}

The percentage of overturn used in computing profit should be gauged by the permanency of the operation, the various elements of risk which attend it, and the local requirements and standards of the particular business. For tie or mining timber operations, with the cut contracted in advance and the market risk thus eliminated, 20 per cent may be taken as standard on fairly accessible chances which involve no unusual logging hazards. In saw-timber sales subject to the usual market risks, 25 per cent should be used under average conditions. If, on the other hand, inaccessible timber must be opened up and exceptional risks incurred in log driving or in marketing the cut, a profit of 30 to 35 per cent is equitable.

\section{DISTRIBUTION OF PROFIT AND DEPRECIATION IN MIXED STANDS.}

\section{Prorated on Quantity of Timber.}

In the foregoing instructions profit and depreciation have been prorated evenly over the entire cut. This is the simplest method and is directly applicable where one species is involved. The same method may be used in mixed stands. Average figures for profit and depreciation, together with the operating costs, may ba deducted (1) from the selling price for each species giving directly its stumpage rate, or (2) from an average selling price for all species giving an average stumpage rate, which may then be distributed over the various species on any basis desired.

\section{Prorated on Net Value of Timber.}

It is preferable to prorate the total annual profit and depreciation in mixed stands on value rather than quantity. The final results are the same. Distribution on value, however, furnishes a fairer basis for fixing stumpage rates as between species. It also affords the most logical means of carrying out the Service policy of maintaining a minimum rate for green timber of each species and adjusting stumpage prices on the more valuable timbers so that they will carry the less valuable in the sale. At the same time it facilitates giving due weight in appraisals to differences in producing costs between species, as in reduced milling charges for inferior woods manufactured only into low-grade lumber or timbers.

The most satisfactory method is to prorate the gross annual depreciation and profit over the difference between operating cost and selling price, for the several species in the proportions entering into the annual cut. To illustrate: 
A yearly cut is made up of 4,000,000 feet of sugar pine, 3,000,000 feet of yellow pine, and 2,000,000 feet of white fir. The margins between selling prices and costs of production, exclusive of depreciation and profit, are:

\begin{tabular}{|c|c|c|c|c|}
\hline & Species. & $\begin{array}{l}\text { Selling } \\
\text { price. }\end{array}$ & $\begin{array}{l}\text { Operat- } \\
\text { ing cost. }\end{array}$ & Margin. \\
\hline $\begin{array}{l}\text { Sugar pine... } \\
\text { Yellow pine. } \\
\text { White fir... }\end{array}$ & & $\begin{array}{r}\$ 20 \\
18 \\
15\end{array}$ & $\begin{array}{r}\$ 10 \\
10 \\
9\end{array}$ & $\begin{array}{r}\$ 10 \\
8 \\
6\end{array}$ \\
\hline
\end{tabular}

The total net value, or sum of the margins, over which depreciation and profit may be prorated, is thus:

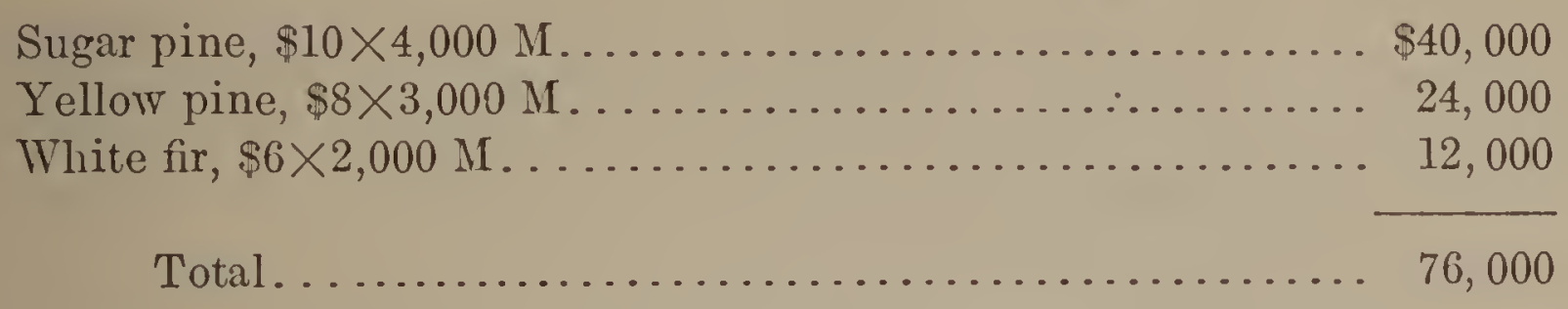

The annual depreciation and profit (using investment method) which must be paid out of this total has been computed as $\$ 34,200$. Hence $\frac{\$ 34,200}{\$ 76,000}=\$ 0.45$. That is, every dollar of margin between operating costs and selling price must pay 45 cents toward profit and depreciation. The following charges per thousand feet for depreciation and profit, by species, are thus obtained:

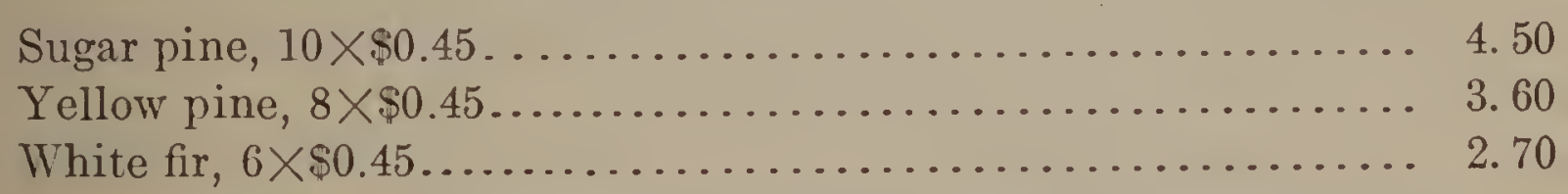

By this method inferior species which yield no margin between operating costs and selling price, or a negative margin, but which must be included in the sale for silvicultural reasons, are automatically relieved of profit and depreciation, and the charge upon the other timbers for these items proportionately increased.

The same result is readily obtained on a thousand-foot basis, using the per cents of the different species in the cut. That is, to obtain the average margin:

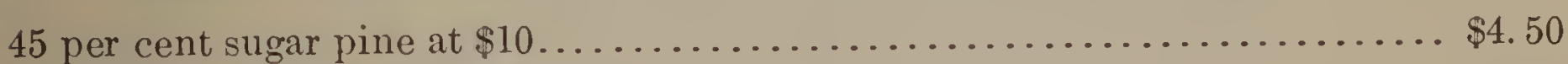

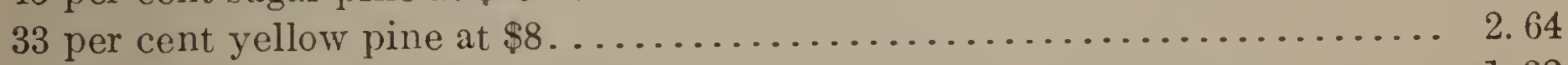

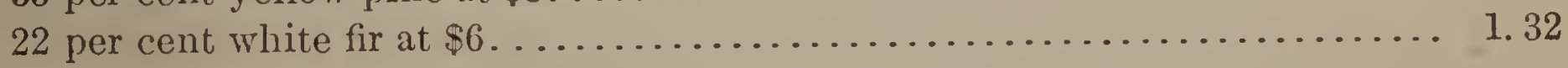

Total........................................ 8.46

Depreciation and profit per $\mathrm{I}$ feet............................ 3.80

$\frac{\$ 3.80}{\$ 8.46}=\$ 0.45$, to be taken from each dollar of margin for these items.

This method of adjusting the prices of the more and less valuable species is believed to accord with customary business practice. Volume of money handled, rather than quantity of this or that product, is the usual basis for figuring carrying charges, depreciation, and returns. In logging, improvements are frequently constructed primarily to take out certain valuable species. Inferior timbers may be cut or left as the market warrants. In such cases operators will usually cut inferior species if a profit can be netted over bare operating costs, figuring that the cost of improvements is borne wholly by the better stuff. The foregoing is believed to be a logical and rational application of this principle. 


\section{STUMPAGE PRICE.}

How Obtained in Mixed Stands.

The value of stumpage is taken, in Forest Service appraisals, to be the portion of the lumber selling price left after deducting operating costs, depreciation, and profit. In mixed stands it should be obtained for each species by deducting these charges from its own lumber price. Depreciation and profit should be prorated over the cut on a net value basis, as described on pages 44 and 45 .

\section{Flat Rates not Desirable.}

Flat rates for two or more species of different lumber values are not desirable. They may prove inequitable if the proportion of species in the cut differs from that in the estimate; and they tend to make close utilization of inferior species covered by the average price difficult. The standard practice of the Forest Service, therefore, will be to appraise each species having a different lumber value separately and as far as possible upon its own merits. To simplify scaling and cutting reports, however, species whose appraised value does not differ by more than 25 cents may be thrown together under one contract price.

\section{Use of Minimum Stumpage Rates.}

The appraisal of inferior species not infrequently results in very low or negative stumpage prices. It has been deemed advisable to establish a minimum rate of 50 cents per thousand feet for green timber below which no species will be sold. Inferior species will therefore be appraised on their own merits as deternined by lumber price and cost of production as long as the resulting stumpage value is not less than 50 cents per thousand feet. If the calculation brings the price below 50 cents, the appraisal will be at that figure. The prices put upon the nore valuable species in the stand must then be reduced sufficiently to carry the difference and maintain the average profit which is deemed equitable on the entire cut.

Distribation of Loss on Inferior Species.

Such adjustments in the stumpage rates of various species may be made by a simple arithmetical process, as follows:

It is assumed that separate appraisals, on individual lumber price and producing cost, give the following stumpage rates in a mixed stand of California timber:

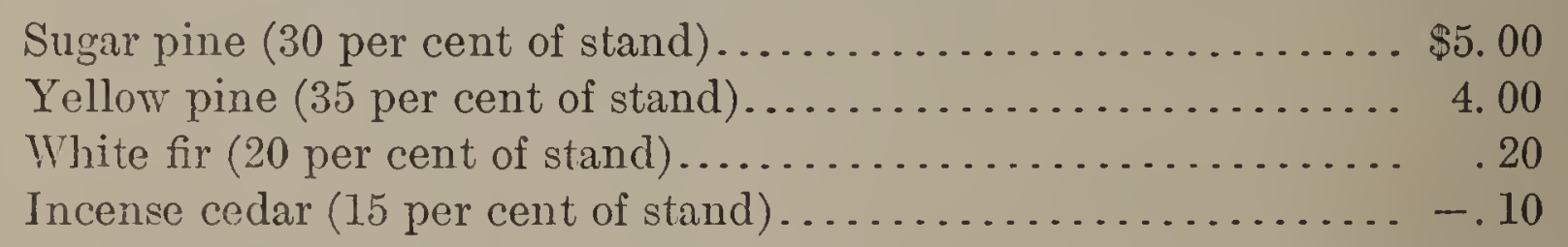

By appraising white fir and cedar at the Service minimum of 50 cents, the amount to be made up on the other species, thousand feet for thousand feet; is 20 per cent of $\$ 0.30+15$ per cent of $\$ 0.60$, or $\$ 0.15$. This amount will be spread over the sugar and yellow pine prices; that is, 30 per cent of $\$ 5+35$ per cent of $\$ 4$, or $\$ 2.90, \frac{\$ 0.15}{\$ 2.90}=$ approximately 5 cents, to be deducted from each dollar of stumpage value in the pines. The adjusted rates are therefore:

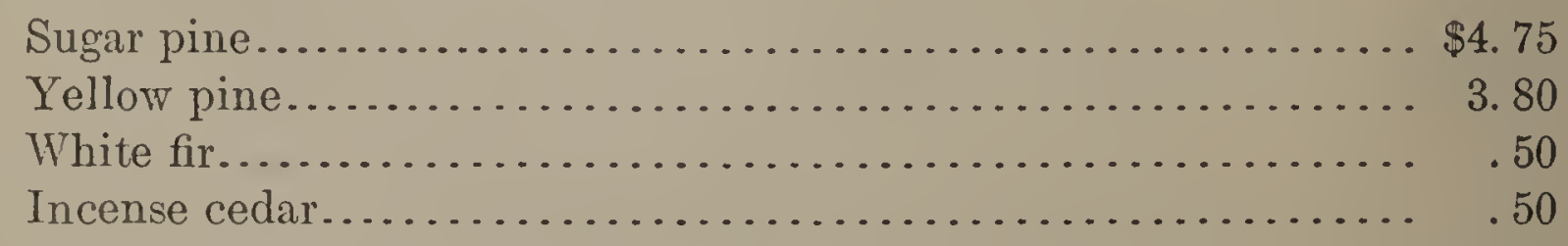

This method should ordinarily be used only when necessary, after profit and depreciation have been prorated on value (see p. 44), to maintain the minimum price.

\section{Trade Valuation of Inferior Species.}

The stumpage rates placed upon inferior species should be checked by trade practice and valuation. Consistent and practical resulfs are desired, conforming as far as possi 
ble with the rating of such timbers by local operators. Standard prices for low-grade species representing the operator's valuation and not below the minimum rate may be lised throughout a region if found to be most practicable and satisfactory. In any event the prices of the better timbers must be adjusted to yield the total profit called for by the appraisal.

\section{Stumpage Prices for Special Products.}

The methods of appraisal previously discussed should be used where the main products of an operation are other than lumber, as shingles, crossties, poles, or mine timbers. Average selling prices will be determimed for the product in the form in which the usual operator disposes of $i$, as manufactured shingles, hewn or slabbed ties, etc., and operating costs back to the stump, depreciation and profit estimated. Rates of profit similar to those discussed for saw-log sales should be allowed in operations of similar size, conditions of accessibility, operating difficulties, and risks, except where other rates have been indicated. (See p. 44.)

Stumpage rates for special products should be based as far as possible upon the unit of measure common in local trade, as the piece in case of poles and crossties, the linear foot for mining timbers, the stacked cord for shingle bolts or fuel, etc.

\section{APPRAISALS FOR SMALL SALES.}

\section{Small Operations Irregular.}

Small operations are seldom as closely organized and well supervised as those of good size and permanence. Equipment is usually less efficient, capital inadequate, and labor frequently unskilled and transient. Costs are hence least uniform in small operations and nearly always proportionately higher. Care must be taken in such appraisals not to impose impracticable standards, but to figure on the level of the conditions found.

\section{Appraisals Based upon Methods in Use.}

It is the policy of the Forest Service to base appraisals in small operations upon the methods of logging and manufacture actually employed, even if comparatively inefficient. As far as practicable, small mills should be classified by output and average costs determined by classes, which cover existing conditions as to character of labor available, anount of capital upon which the business is run, and the kind and effi. ciency of equipment.

Such average costs may be used in appraisals when desirable with only such variations as the particular conditions on each chance require.

\section{Prices Actually Obtained.}

The lumber prices used in such appraisals will similarly be the local prices actually obtained by these small operators, not the prices prevailing in the general manufacturing region.

\section{Liberal Profit Necessary.}

The profits allowed in appraisals for small sales, as indicated on page 41, must be relatively high, averaging more per thousand feet than in larger operations. Thirty to thirty-five per cent on the overturn or 25 per cent on invested capital plus a supervision charge to cover the personal services of the operator should be the general standard in small sales of saw timber subject to the usual market risks. In sales of ties, mining timber, and other material where the entire cut is contracted in advance a profit of 20 per cent on overturn is usually adequate. Lower profits may be used where current sales and bids indicate that they are satisfactory.

\section{Small Operations Competing in General Markets.}

For small operations whose product is sold in general markets in competition with large plants the average lumber prices prevailing in such markets will necessarily be taken as the basis of appraisals. The grade and quality of the product, which is usually 
poorer than lumber manufactured by large mills, should, however, be considered. Otherwise the policy indicated above as to efficiency of methods and labor and scale of profits will be followed.

As indicated under "Size and type of plants," page 13, investments will be estimated and appraisals made on the basis of small operations wherever it is practicable for them to handle the timber.

If larger operations are clearly more practicable and logical, however, and the timber has been appraised accordingly, the resulting prices must be paid by any purchaser who takes the stumpage. Two standards of value obviously can not be set for the same material. Under such circumstances no concessions to the inefficiency of the small operator can be made.

Schedules of Prices for Small Sales.

District Foresters may authorize Supervisors to establish schedules of stumpage prices for specified parts of their Forests to be used in small sales. This should be done only where conditions are so generally uniform that differences in intensive appraisals of the various sale areas involved would be slight. Such schedules should be worked out under the Supervisor's direction in accordance with the methods described in these instructions, by the use of average selling prices, logging costs, and investments.

\section{SAFEGUARDS AND CHECKS.}

\section{Check by Appraiser's Judgment.}

As indicated on page 11, all appraisals should be checked by the judgment and business sense of the appraiser. The prices actually recommended should be plainly stated, with the considerations on which they are based, as well as the rates obtained by strict application of these instructions.

\section{Check by Money Profit per Thousand Feet.}

As indicated on page 39, the dcllars and cents profit per thousand feet is a direct and tangible check which should always be used. Viewing the timber, the chance, and the investment in a broad way, and comparing them with corresponding operations, the appiaiser should satisfy himself as to the fairness and sufficiency of this amount.

\section{Prices Bid in Former Sales.}

Prices bid for timber in previous sales, with due allowance for differences in quality, accessibility, and other telling conditions, also afford an excellent check. As far as practicable their fairness should be gauged by observation of the succeeding operations. Bid prices are of special value as checks because indicating just what local operators, under all the conditions involved, National Forest sale regulations included, are willing to pay for stumpage. As a general rule, the rate of profit indicated by current bids should govern appraisals in timber comparable in quality and accessibility.

Current Stumpage Appraisals.

Uniform stumpage rates for timber of the same general quality and accessibility in a given region stabilize the sales business and promote the confidence of purchasers. They also afford an excellent check against hasty or erroneous appraisals. Prevailing prices should never be applied to the ignoring of the quality of the timber and the production costs on a particular chance. The appraiser should, however, check his results by the going and accustomed rates for the general type of stumpage and location, and satisfy himself that any departures are justified. Points of this nature should be covered in appraisal reports.

Prices of Private Timber.

A further check is afforded by the rates at which private commercial stumpage is held or sold. When owned by timbermen who know its worth, particularly in regions where buying is active, the price of privately awned stumpage represents the consensus of business judgment as to the sum total of all factors, fluctuating lumber 
markets: reasonable profits, and logging risks included. Care must of course be exercised to consider timber which is comparable in quality and availability and to take only prices obtained by owners who are able to secure full value. Another point of great importance, particularly in comparisons between large tracts, is that, in the case of privately owned timber, carrying charges for interest and taxes in effect double the investment every ten years. Under National Forest sales, with no taxes, no interest on deferred payments, and deposits for stumpage only in small installments in advance of cutting, no such increase in the initial investment takes place. This may be offset by the gain to the private owner from increasing values of lumber which is only realized in part by the operator under a National Forest contract. As a general rule, however, private stumpage in large blocks is worth less than similar stumpage on a National Forest.

\section{METHODS OF APPRAISING STUMPAGE; APPLICATION OF PRINCIPLES PREVIOUSLY DISCUSSED.}

The application of the principles of appraioing stumpage which have been dis. cussed is illustrated by the following concrete examples.

\section{SYMBOLS FOR ELEMENTS IN APPRAISAL.}

For convenience in appraisals, the following symbols will be used for various elements in the calculation. For uniformity and ease in checking, any symbols employed-and their use is entirely a matter of convenience-should conform with those given. The symbols are all in terms of one thousand board feet.

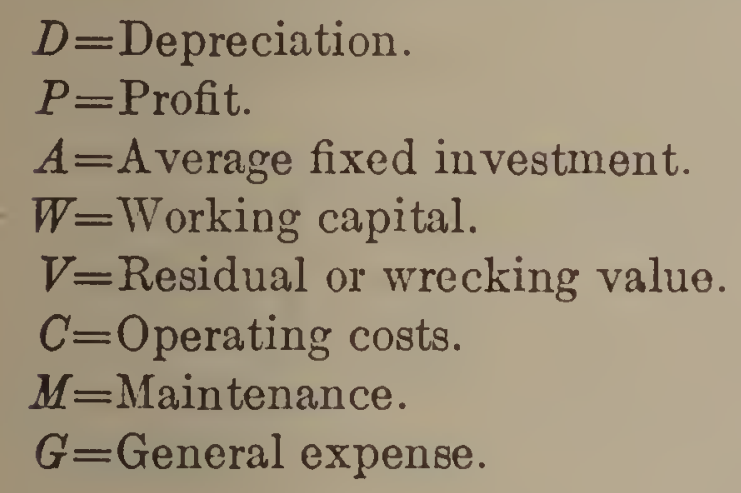

$T=$ Taxes and insurance.

$R=$ Extra costs of logging due to Service regulations.

$S=$ Selling price of lumber.

$X=$ Stumpage price.

$L c=$ All logging costs.

$M c=\Lambda l l$ manufacturing costs.

\section{EXAMPLES OF THE INVESTMENT METHOD.}

In the three examples following, the investment method of computing profit has been used.

\section{A SMALL OPERATION IN THE ROCKY MOUNTAINS.}

A total stand of $12,610 \mathrm{M}$ feet is available to a central mill site, of which $9,000 \mathrm{M}$ feet may be cut under the established methods of marking. This consists of green Douglas fir, 76 per cent; green Engelmann spruce, 22 per cent; and merchantable dead timber of both species, 2 per cent.

The applicant's mill is at present located 8 miles from the new setting. The initial cost of this mill was $\$ 6,000$. It has been operated 3 years out of a total life for small semiportable plants of this type of 10 years. It is therefore reckoned as having depreciated one-third and is now rated at $\$ 4,000$. A cut of $9,000 \mathrm{M}$ feet will last it 6 years, at which time it will have an approximate wrecking value of $\$ 1,000$. The appraisal is therefore based upon an operation of 6 years.

The present value of the operator's logging equipment, horses, sleds, lumber trucks, harness, tools, etc., is put at $\$ 5,000$. Its depreciation is figured at the rate of $\$ 600$ per year, leaving a residual value at the end of the operation of $\$ 1,400$. The operating costs for which working capital is required total $\$ 12.75$ per thousand feet log scale,

$60813-14-4$ 
or $\$ 19,125$ for the year's cut. ${ }^{1}$ The bulk of the lumber is sold and paid for within six months after felling, the average turn of the working capital being four months. On this basis, with a small margin for contingencies, working capital is figured at $\$ 8,000$.

The investments and depreciations may be summarized in the standard form, all investments being made the first year, and all depreciations prorated evenly over 6 years.

\begin{tabular}{|c|c|c|c|c|}
\hline Item. & $\begin{array}{l}\text { Initial in- } \\
\text { vestment. }\end{array}$ & $\begin{array}{l}\text { Yearly de- } \\
\text { preciation. }\end{array}$ & $\begin{array}{l}\text { Wrecking } \\
\text { value. }\end{array}$ & $\begin{array}{c}\text { Average } \\
\text { profit- } \\
\text { bearing } \\
\text { investment. }\end{array}$ \\
\hline 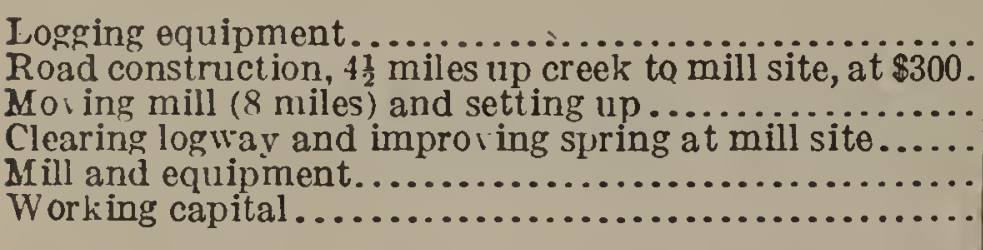 & $\begin{array}{r}\$ 5,000 \\
1,350 \\
350 \\
100 \\
4,000 \\
8,000 \\
\end{array}$ & $\begin{array}{r}\$ 600.00 \\
22.5 .00 \\
58.33 \\
16.67 \\
500.00 \\
\cdots\end{array}$ & 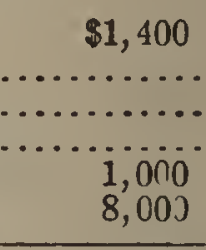 & $\begin{array}{r}\$ 3,500.00 \\
787.50 \\
204.17 \\
58.33 \\
2,750.00 \\
8,000.00 \\
\end{array}$ \\
\hline Total... & 18,800 & $1,400.00$ & 10,400 & $15,300.00$ \\
\hline
\end{tabular}

In accordance with the standard policy for such operations as given on page 41 , a profit of 25 per cent on the average investment will be allowed; 25 per cent of $\$ 15,300$ is $\$ 3,825$. This, with the yearly depreciation of $\$ 1,400$, makes a total of $\$ 5,225$ to be prorated over the annual cut. The equivalent charge per thousand feet log scale is $\frac{\$ 5.225}{1,500 \mathrm{M}}$, or $\$ 3.48$ per thousand feet. Two dollars and fifty-five cents of thi amount is profit and 93 cents depreciation.

The logging costs may be summarized as follows, all in thousand board feet log scale:

\begin{tabular}{|c|c|c|c|c|c|c|}
\hline Item. & C. & M. & G. & $\mathrm{T}$. & $\mathrm{R}$. & Total. \\
\hline 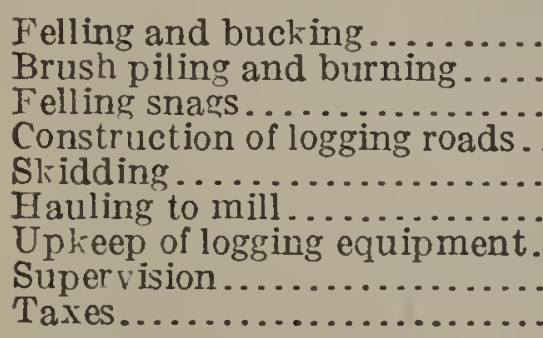 & $\begin{array}{r}\$ 1.10 \\
\ldots \ldots \\
\ldots .25 \\
1.60 \\
1.50\end{array}$ & $\$ 0.10$ & $\begin{array}{r}\$ 1.00 \\
\ldots \ldots\end{array}$ & $\$ 0.02$ & $\begin{array}{r}\$ 0.40 \\
.05\end{array}$ & $\begin{array}{r}\$ 1.10 \\
.40 \\
.05 \\
.25 \\
1.60 \\
1.50 \\
.10 \\
1.00 \\
.02\end{array}$ \\
\hline & 4.45 & .10 & 1.00 & .02 & .45 & 6.02 \\
\hline
\end{tabular}

Logging roads are short, used for the most part less than one year. It is therefore simpler to charge the cost of their construction to operating expenses rather than to fixed investment.

Supervision is inserted to cover the personal services of the operator. This is based upon an annual salary of $\$ 1,500$ spread over the cut. Although in fact applying to the whole operation, it may as conveniently be charged against logging as split between logging and milling. This charge is higher per thousand feet than in a large, efficiently organized operation. Its inclusion is necessary, however, to provide adequately for the element of personal initiative and enterprise in a sale of this character.

1 This includes an assumed stumpage rate of $\$ 3$, all logging costs except supervision and all milling costs extended to log scale by 10 per cent overrun. The supervision charge is, in this instance, a return to the operator himself, coming at the end of the year or whenever a surplus accumulates. It need not, therefore, be covered by working capital. The transportation charge from mill to market is also elininated, since it is incurred just prior to salo and can be assumed fairly as paid by a portion of the product. 
Taxes are obtained as a 1 per cent valuation of the average investment in logging equipment prorated over the annual cut. This is based upon an assessment of onethird of the actual value and a levy of 3 cents on the dollar.

Milling costs may be summarized likewise, per thousand feet lumber tally.

\begin{tabular}{|c|c|c|c|c|}
\hline Item. & C. & M. & $\mathrm{T}$. & Total. \\
\hline 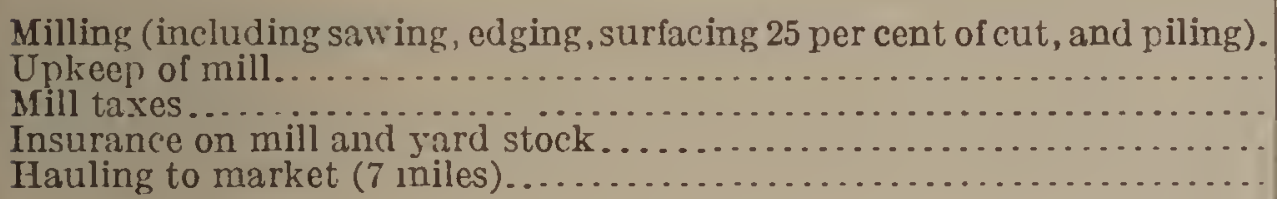 & $\begin{array}{l}\$ 4.00 \\
\ldots . . \\
2.50\end{array}$ & $\begin{array}{r}\$ 0.20 \\
\ldots . . .\end{array}$ & $\begin{array}{r}80.04 \\
.06 \\
.\end{array}$ & $\begin{array}{r}\$ 4.00 \\
.20 \\
.04 \\
.08 \\
2.50\end{array}$ \\
\hline Total. & 6.50 & .20 & .10 & 6.80 \\
\hline
\end{tabular}

The figure of $\$ 4$ for milling is the average of 4 mills of this general type and output in the region.

Mill taxes are computed, like logging taxes, as 1 per cent of the average value of the property. This includes 330,000 feet of lumber, or two months' cut, ${ }^{1}$ which is assumed to be carried steadily on hand. Insurance is figured as a 2 per cent premium on three-fourths of the average value of mill and yard stock. ${ }^{2}$

Selling costs are included in the supervision item of $\$ 1$, this part of the work being handled by the operator personally.

The lumber is marketed in an agricultural valley, the distributing point being approximately 7 miles by wagon haul from the mill. Seventy-five per cent of the cut of green timber of both species is sold in the rough as boards and dimension stock, at a delivered rate of $\$ 16$. Twenty-five per cent is surfaced for finish and sold at a delivered rate of $\$ 24$. The average lumber selling price of green timber is thus:

75 per cent rough and dimension at $\$ 16 \ldots \ldots \ldots \ldots \ldots \ldots \ldots \ldots 12$

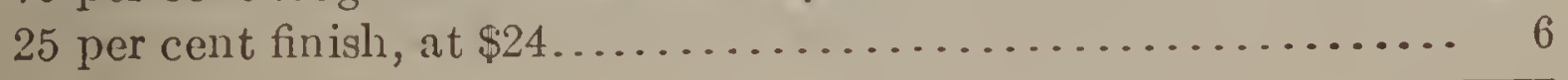

A verage selling price.......................... 18

Dead timber is all cut into rough boards. On account of stain and check, it commands a lower price than green, averaging $\$ 15$ per thousand feet. The stumpage arerages $16 \operatorname{logs}$ per thousand feet. With a circular saw of one-fourth inch kerf and relatively inefficient methods of manufacture, overrun can not be placed conservatively at more than 10 per cent.

The average lumber selling prices extended to log scale are thus:

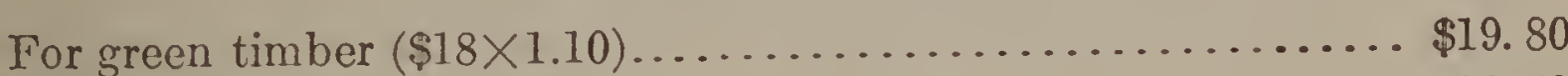

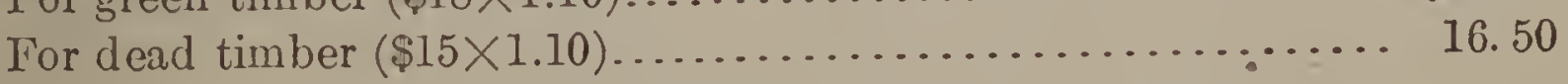

The milling and haulage costs, similarly extended, to tal $\$ 7.48$.

Stumpage rates may then be determined by the formula, $X=S-L c-M c-D-P$, all in terms of log scale, as follows:

For green timber: $\$ 19.80-\$ 6.02-\$ 7.48-\$ 0.93-\$ 2.55=\$ 2.82$.

For dead timber: $\$ 16.50-\$ 16.98$, as above, $=-\$ 0.48$.

1 It is assumed that the mill will operate 10 months in the year, cutting 150,000 feet of logs per month, or figuring overmin at 10 per cent, 165,000 feet of lumber.

2 The average value of the mill used in calculating taxes and insurance is $\$ 2,750$, the average interest. bearing investment. The value of the yard stock of 330,000 feet is: $\Lambda$ ssumed stumpage rate, $\$ 3$, and logging costs, exclusive of supervision, $\$ 5.02$, both reduced to mill-tally basis; that is, $\frac{\$ \$ .02}{\$ 1.10}=\$ 7.29$; together with milling costs, $\$ 4.20$. The latter exclude taxes, insurance, and haulage. The total of $\$ 11.49$ times 330,000 makes the average yard stock worth $\$ 3,791.70$. 
Putting a minimum price of 50 cents on the dead stumpage, the final prices become:

2 per cent of $\$ 0.98$ (difference to be made up) ................... $\$ 0.0196$ 98 per cent of $\$ 2.82$ (on which difference is to be prorated)............... 2.76 $\frac{\$ 0.0196}{\$ 2.76}=\$ 0.0071$, reduction for each dollar in the price of green timber.

Hence the final prices become: For dead timber, $\$ 0.50$ per thousand feet; for green timber, $\$ 2.80$ per thousand feet.

The total return of the operator under this calculation is $\$ 1$ for supervision (personal services) and $\$ 2.55$ on his investment, or $\$ 3.55$. This is deemed equitable for small operations of this type, and checks closely with the monetary profit at which such operations are rated on page 40.

(Initial capital, $\$ 18,800$; output, under 10,000 feet daily.)

\section{A MIDDLE-SIZED OPERATION IN THE BLUE MOUNTAINS.}

This chance will cut approximately 80,000,000 feet. Eighty per cent of the stand is yellow pine, the remainder Douglas fir and western larch. The operation is planned for 10 years at an annual cut, log scale, of $8,000,000$ feet.

The central point of the business is on a trunk line railroad where the planing mill is located. It has a rated value of $\$ 15,000$. It will be well maintained with a view to succeeding operations and should have a residual value of $\$ 10,000$ at the end of the sale. From this central point, an existing common carrier railroad, forming a tap line or feeder for the main system, runs near the chance. It is proposed to build a single band mill, with a capacity of 40,000 feet of lumber daily, on the sale area. It will cost $\$ 30,000$ and have a residual value of $\$ 10,000$ at the end of the operation. Freight on green rough lumber between these points is equivalent to $\$ 2.50$ per thousand feet.

Five miles of railroad connecting the mill with the tap line and running up into the woods will be used during the entire operation. Its estimated cost beneath the steel is $\$ 1,900$ per mile. In addition, the following branches will be required: (1) A lateral 2 miles long, to be used 2 years; (2) A lateral 5 miles long, to be used 5 years; (3) Short spurs, totaling 12 miles, to be used on the average 1 year. These laterals and spurs will cost on the average $\$ 1,200$ per mile beneath the steel; 9 miles of steel all told will be required. This will cost $\$ 2,200$ per mile, and is estimated to be worth half that amount at the end of the operation.

One light engine with gypsy loader and rolling stock, costing all told $\$ 12,000$, are required for log hauling. Their residual value is estimated at $\$ 3,000$.

For logging to rail, eight teams will be required. Their cost with harness is $\$ 400$ each. Skidding equipment will cost $\$ 2,000$. The maintenance charge on teams and skidding outfits will necessarily be heavy, amounting to $\$ 800$ a year. With this expenditure for maintenance, however, the value of the equipment will be kept close to its initial cost. It residual value may therefore bu reckoned at $\$ 3,000$.

Further items of investment may be listed as follows:

\begin{tabular}{|c|c|c|}
\hline Item. & Amount. & $\begin{array}{l}\text { Residual } \\
\text { value. }\end{array}$ \\
\hline $\begin{array}{l}\text { Wood camps................... } \\
\text { Shop and tools................. } \\
\text { Woods and track tools......... } \\
\text { Working capital................ }\end{array}$ & $\begin{array}{r}\$ 2,000 \\
1,500 \\
500 \\
35,000\end{array}$ & 35,000 \\
\hline
\end{tabular}

The working capital is computed as follows: Current costs for logging and stumpage will be turned every four months. These aggregate $\$ 6.28$, including an assumed 
stumpage rate of $\$ 3$ for pine (80 per cent) and $\$ 1$ for fir and larch $(20$ per cent). The freight and milling costs, which average $\$ 8.53, \log$ scale, for all species, are turned every two months. The working capital required is thus $\frac{\$ 6.28}{3}+\frac{\$ \$ .53}{6}$, or $\$ 3.51$ for each

thousand feet, $\log$ scale, in the year's cut. On $8,000,000$ feet this amount to $\$ 28,080$. Twenty-five per cent has been added as leeway for contingencies, making the total $\$ 35,000$.

The investments and depreciations may be summarized as follows:

\begin{tabular}{|c|c|c|c|c|c|}
\hline Item. & $\begin{array}{c}\text { Initial } \\
\text { investment. }\end{array}$ & $\begin{array}{l}\text { Number } \\
\text { of years } \\
\text { used. }\end{array}$ & $\begin{array}{l}\text { Annual } \\
\text { deprecia- } \\
\text { tion. }\end{array}$ & $\begin{array}{l}\text { Residual } \\
\text { value. }\end{array}$ & $\begin{array}{c}\text { A verage } \\
\text { profit-bearing } \\
\text { investment. }\end{array}$ \\
\hline 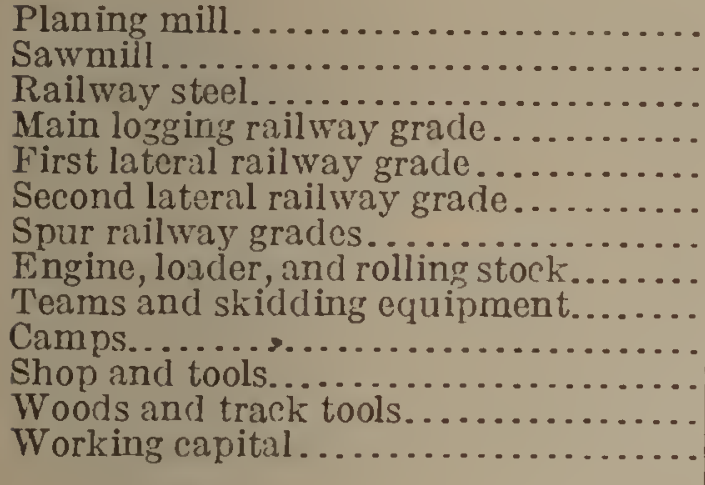 & $\begin{array}{r}\$ 15,000 \\
30,000 \\
19,800 \\
9,500 \\
2,400 \\
6,000 \\
14,400 \\
12,000 \\
5,200 \\
2,000 \\
1,500 \\
500 \\
35,000\end{array}$ & $\begin{array}{r}10 \\
10 \\
10 \\
10 \\
2 \\
5 \\
1 \\
10 \\
10 \\
10 \\
10 \\
10 \\
10\end{array}$ & $\begin{array}{r}\$ 500 \\
2,000 \\
990 \\
950 \\
240 \\
600 \\
1,440 \\
900 \\
220 \\
200 \\
100 \\
50\end{array}$ & 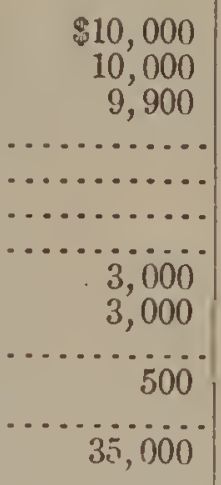 & $\begin{array}{r}\$ 12,750 \\
21,000 \\
15,345 \\
5,225 \\
360 \\
1,800 \\
1,440 \\
7,950 \\
4,210 \\
1,100 \\
1,050 \\
275 \\
35,000\end{array}$ \\
\hline Total & 153,300 & & 8,190 & 71,400 & 107,505 \\
\hline
\end{tabular}

The average investment at work in the operation and entitled to profit is thus $\$ 107,505$. Former competitive bids for timber in this region, which is relatively accessible and involves but average risks, and for chances which are comparable in size and permanency of the operation indicate that a return of 15 per cent on the investment is a fair going basis for sales of National Forest stumpage. At this rate the annual profit (18 per cent of $\$ 107,505$ ) amounts to $\$ 19,350.90$, or $\$ 2.42$ per thousand feet, log scale.

The annual depreciation charge is $\frac{\$ 8,190}{8,000 \mathrm{M}}$ or $\$ 1.02$ per thousand feet, log scale.

The operating costs are estimated as follows:

Logging per 1,000 feet log scale.

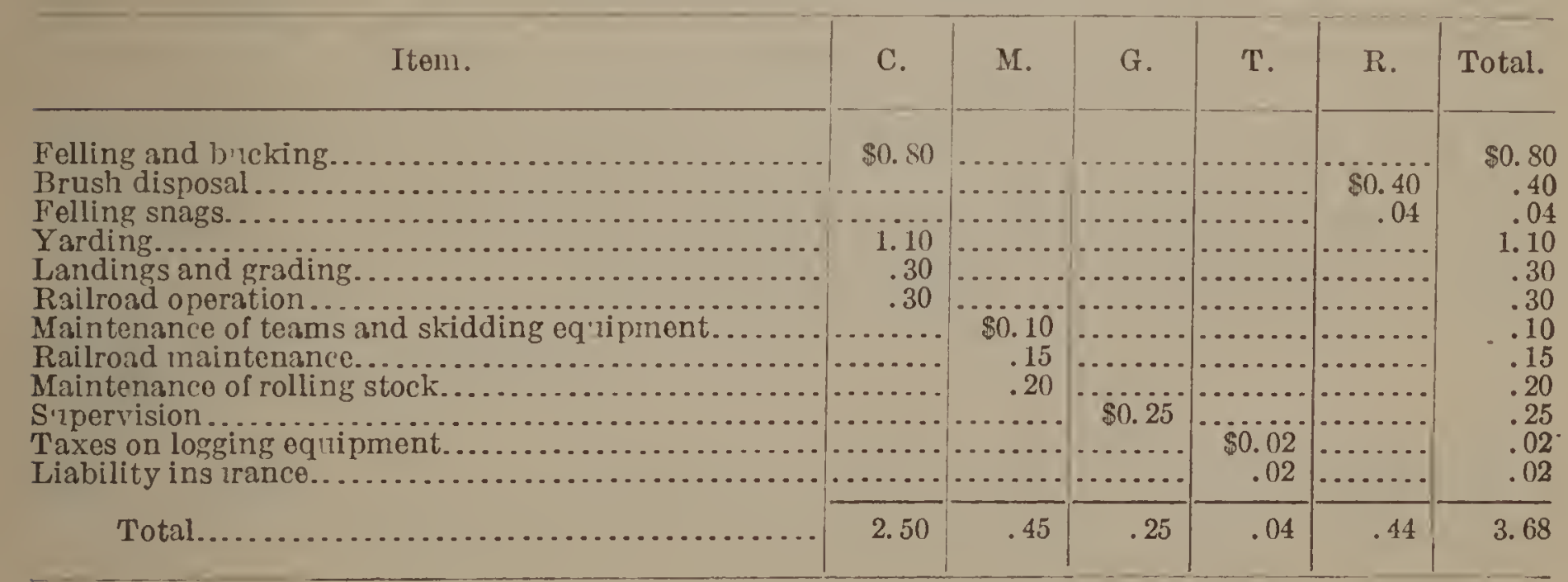


Manufacture and transportation per 1,000 feet lumber tally.

\begin{tabular}{|c|c|c|c|c|c|}
\hline Item. & C. & M. & G. & T. & Total. \\
\hline 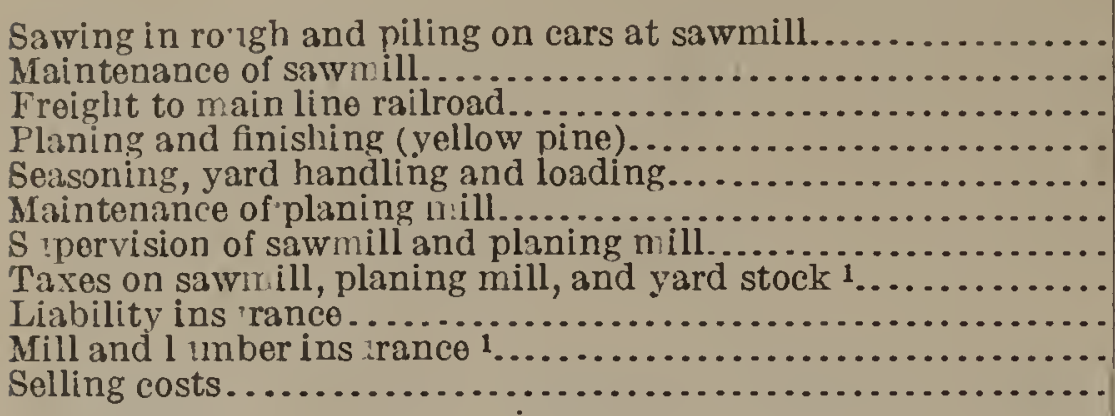 & $\begin{array}{r}\$ 1.90 \\
\cdots . \\
2.50 \\
2.10 \\
.60 \\
\ldots \ldots \ldots\end{array}$ & $\begin{array}{r}\$ 0.20 \\
\cdots \ldots . . \\
\cdots \cdots . \\
\cdots \\
.10\end{array}$ & $\begin{array}{c}\$ 0.20 \\
\cdots . . . \\
.30 \\
\cdots \\
.30\end{array}$ & $\begin{array}{r}\$ 0.06 \\
.01 \\
.07 \\
\ldots . . .\end{array}$ & $\begin{array}{r}\$ 1.90 \\
.20 \\
2.50 \\
2.10 \\
.00 \\
.10 \\
.20 \\
.06 \\
.01 \\
.07 \\
.07\end{array}$ \\
\hline Total.. & 7.10 & .30 & .50 & .14 & 8.04 \\
\hline
\end{tabular}

1 In these items the average yard stock carried at the planing mill is p - $t$ at $1,200,000$ feet of pine and 300,000 feet of larch and fir. J'ine is credited with an average cost of $\$ 13.67$, and larch and fir with an averago c'ost of $\$ 10.45$. These are based tpon (1) ass uned st :mpage rates of $\$ 3$ for pine and $\$ 1$ for larch and fir, (2) logging costs of $\$ 3.68$ and (3) milling and transportation costs of $\$ 7.60$ and $\$ 6.20$, res ve tively. St !n page charges and logging costs are reduced for 10 per cent overr.in. Milling costs are excl sive of taxes, ins rance, and selling charges.

Not more than 20 per cent of the larch and fir lumber is dressed as compared with 60 per cent of the pine lumber. The average cost of planing and finishing larch and fir is therefore 70 cents per 1,000 feet on the total of these species. The total cost of manufacture and transportation in the case of larch and fir is therefore $\$ 1.40$ less than for pine, or $\$ 6.64$.

This timber runs from 8 to 10 logs per 1,000 feet. Results obtained in current sales, however, indicate that an overrun exceeding 10 per cent can not be used safely in stumpage appraisals. Extended for this overrun, the milling and transportation cost for yellow pine, log scale, is $\$ 8.04 \times 1,100$, or $\$ 8.84$; and for larch and Douglas fir, $\$ 6.64 \times 1,100$, or $\$ 7.30$.

From study of current manufacture of similar timber in local mills and compilation of selling prices during the past two years, the average cut and selling price of yellow pine, by grades, are ascertained to be as follows:

\begin{tabular}{|c|c|c|c|}
\hline Grade. & $\begin{array}{c}\text { Per cent of } \\
\text { cist. }\end{array}$ & Grade price. & $\begin{array}{l}\text { Weight in } \\
\text { areraqe } \\
\text { price. }\end{array}$ \\
\hline 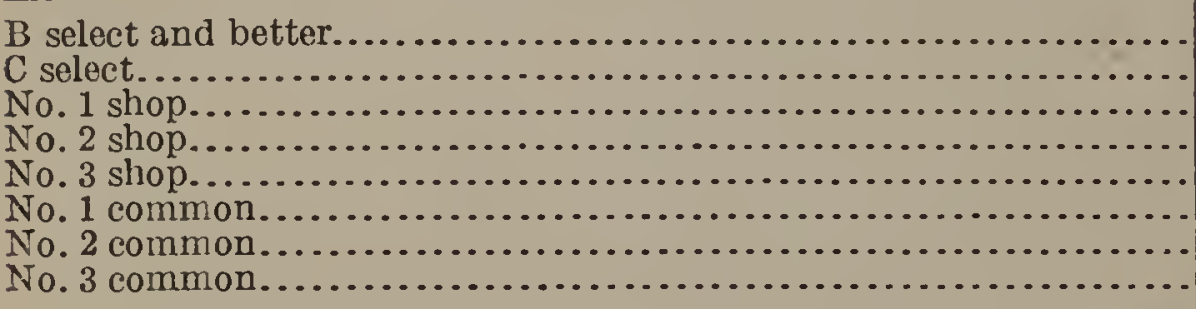 & \begin{tabular}{r|}
2 \\
8 \\
15 \\
20 \\
25 \\
20 \\
5 \\
5
\end{tabular} & $\begin{array}{r}\$ 46.00 \\
34.00 \\
24.00 \\
16.00 \\
12.50 \\
14.00 \\
12.00 \\
10.00\end{array}$ & $\begin{array}{r}\$ 0.92 \\
2.72 \\
3.60 \\
3.20 \\
3.12 \\
2.80 \\
.60 \\
.50\end{array}$ \\
\hline Total... & 100 & & 17.46 \\
\hline
\end{tabular}

The average cut and selling price of western larch and Douglas fir, by grades, have been similarly ascertained to be approximately as follows:

\begin{tabular}{|c|c|c|c|}
\hline Grade. & $\begin{array}{c}\text { Per cent of } \\
\text { cut. }\end{array}$ & Grade price. & $\begin{array}{l}\text { Weight in } \\
\text { average } \\
\text { price. }\end{array}$ \\
\hline 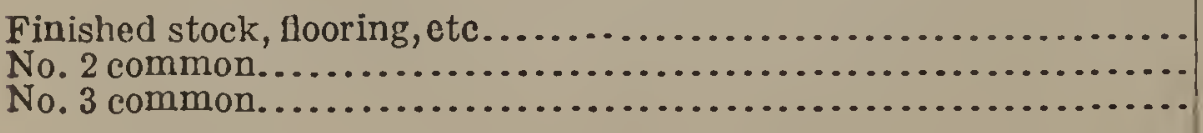 & $\begin{array}{r}6 \\
54 \\
40\end{array}$ & $\begin{array}{r}\$ 16.00 \\
12.00 \\
10.00\end{array}$ & $\begin{array}{r}\$ 0.96 \\
6.48 \\
4.00\end{array}$ \\
\hline Total. . & 100 & & 11.44 \\
\hline
\end{tabular}

Extended by 10 per cent overrun, the average selling prices, log scale, are:

For yellow pine, $\$ 17.46 \times 1,100$, or $\$ 19.21$. To this should ba added $\$ 0.30$, the net return per thousand feet log scale from the sale of slabwood $(0.5$ cord per thousand at $\$ 0.60)$.

For larch and Douglas fir, $\$ 11.44 \times 1,100$, or $\$ 12.58$. 
The stumpage rates may now be calculated as follows:

For yellow pine:

Average selling price.

Depreciation

Profit. .

2.42

Logging.

3.68

Manufacture and transportation

8.84

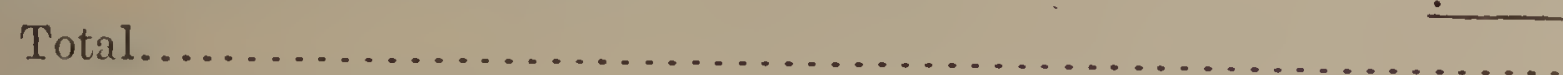

Balance for stumpage............................... 9.96

For larch and Douglas fir:

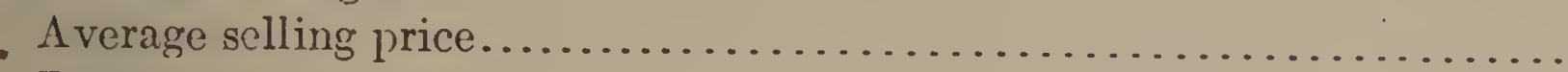

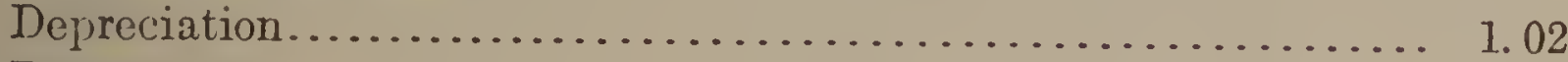

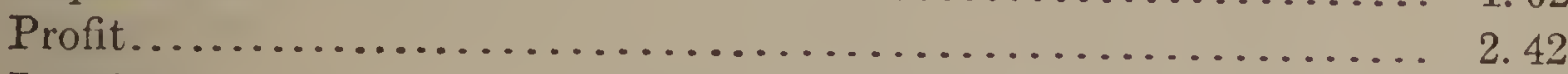

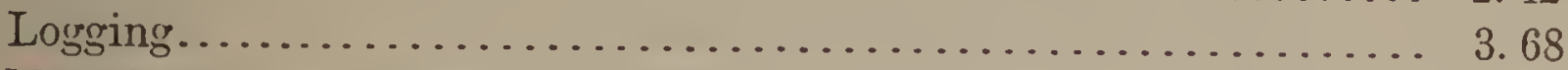

Manufacture and transportation....................... 7.30

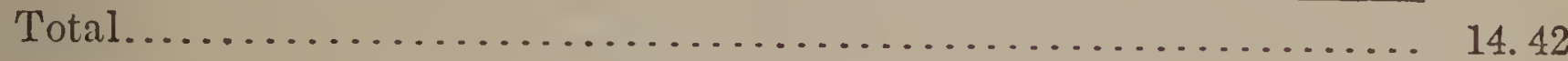

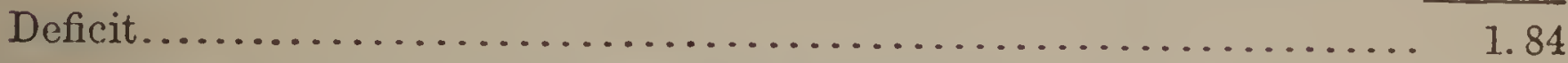

Establishing the minimum rate of 50 cents per thousand feet for larch and Douglas fir, the total deficit of $\$ 2.34$ on these species may be distributed on the pine stumpage as follows:

Twenty per cent of $\$ 2.34$ is $\$ 0.47$, the amount to be taken up by the stumpage price of pine.

Eighty per cent of $\$ 3.55$ is $\$ 2.84$, the average stumpage rate which must carry this deficit. $\frac{\$ 0.47}{\$ 2.84}=\$ 0.165$, to be deducted from each dollar of stumpage value of yellow pine.

The final stumpage rates are thus: For yellow pine, $\$ 2.97$ per thousand feet; for larch and Douglas fir, $\$ 0.50$ per thousand feet.

Prorating the annual charge for depreciation and profit on net value instead of quantity, in accordance with the principles discussed on page 44 , stumpage prices by species are obtained as follows:

Deducting operating costs only from average selling prices, the margin is: For yellow pine, $\$ 6.99$ per thousand feet, log scale; for larch and fir, $\$ 1.60$ per thousand feet, log scale.

With a yearly cut of $6,400,000$ feet of pine and $1,600,000$ feet of larch and fir, the total margin is $\$ 47,296$. The sum of yearly depreciation and profit is $\$ 27,541$. Dividing the latter figure by the former, it is ascertained that each dcllar of margin must pay $\$ 0.582$ toward depreciation and profit. On yellow pine, therefore, these charges amount to $\$ 4.07$ per thousand feet, leaving $\$ 2.92$ for stumpage. On larch and fir, they amount to $\$ 0.93$ per thousand feet, leaving $\$ 0.67$ for stumpage. The average price is the same as that obtained under the first computation. The second method is to be preferred as more logical and less arbitrary.

\section{A LARGE OPERATION IN THE IDAHO PANHANDLE.}

This chance is estimated to cut, under Service methods of marking, 600,000,000 feet in a 20 -year operation. The timber consists of the following species:

\begin{tabular}{|c|c|c|}
\hline \multicolumn{2}{|c|}{ Per cent. } & Per cent. \\
\hline$\ldots \ldots \ldots \ldots \ldots$ & 27 & Western larch and Douglas fir...... 33 \\
\hline Yellow pine. & 4 & Western red cedar.............. 25 \\
\hline Lodgepole pine.................. & 1 & White fir....... \\
\hline ngelmann spruce............... & 3 & \\
\hline
\end{tabular}


The chance is exceptionally adapted to railroad logging. From a central point, where the system of logging spurs would logically begin, the most practicable route to the nearest railroad connections requires 32 miles of track. The first 20 miles of this distance taps a region of extensive agricultural resources. Behind it lies a heavily timbered belt which contains upward of 6,000,000,000 feet. There is little doubt that permanent traffic in timber and agricultural products will maintain this portion of the railroad as a common carrier, and that considerable freight outside of the National Forest sale will contribute to its support from the outset.

The cost of this portion of the railroad is estimated at $\$ 20,000$ a mile. Two-fifths of the total expenditure of $\$ 400,000$ will be made two years, and three-fifths one year in advance of the beginning of the operation. Including interest on these amounts, for two and one years, respectively, at 6 per cent, the initial investment is computed as $\$ 433,600$. This investment does not depreciate, but with adequate charges for maintenance remains intact throughout the operation. The permanent traffic then available will give it a residual value equal to the first cost.

In the stumpage appraisal this tap-line railroad may be treated in either of two ways.

First, it may be handled as an integral part of the operation, like other investments. In that case, because of its permanency and low risk, a return of 10 per cent annually is believed to be equitable. It is but fair, furthermore, to charge a portion of this return to the outside traffic available for the road. It is the appraiser's judgment that such outside traffic during the sale period as a whole should net $\$ 25,000$ a year over and above its proportionate share of the cost of rolling stock, operation, and maintenance. This leaves $\$ 18,360$ as the annual charge for profit on the tap line to be borne by the National Forest stumpage, in addition to its portion of the cost of operation, maintenance, and rolling stock.

Second, the tap line may be regarded as an independent business enterprise. In this case its only relation to the timber sale is as a common carrier which will transport the product on a freight-tariff basis. A freight-tariff, under this assumption, is thus substantiated for the combined charges for rolling stock, operation, maintenance, and profit under the first assumption. In comparison with other railroads making similar hauls, the freight rate is figured at 55 cents per thousand feet of $\log s, \log$ cars being furnished and maintained by the shipper.

The remaining 12 miles of railroad will be a logging road primarily, but will tap fully as much private as Government timber. From careful study of the location and ownership of this timber, it is concluded that to prorate the cost of the logging railroad three-fifths to the National Forest chance and two-fifths to adjacent private stumpage will be safe and equitable. The cost of this main logging road, or feeder, including steel, is put at $\$ 6,000$ per mile. The initial investment, $\$ 43,200$ of which is to be carried by the Government timber, will be fully depreciated during the 20 -year period allowed for the operation. The average investment in the feeder should return the same profit allowed for the capital used in the operation as a whole.

The best location for a manufacturing plant is 92 miles from the chance, at a goodsized valley town. The low elevation, making conditions for seasoning lumber and continuous operation of the mill much more favorable, and better facilities for railroad shipments more than offset the distance from the timber. This location will require a log haul of 60 miles from the end of the tap line over an existing railroad, at a quoted charge of 80 cents per thousand feet log scale with cars furnished by the siipper.

The manufacturing site is estimated to cost $\$ 25,000$. This will be a permanent investment, in a rapidly growing town, subject to no risk and with every prospect of appreciation in value. As in the case of the tap line, therefore, no depreciation wil be figured and a return of 10 per cent throughout the life of the sale will be adequate. With an annual cut of $30,000,000$ feet, this will amount to approximately 8 cents per thousand feet, log scale. The plant itself, a double-band sawmill and planing mill, will cost $\$ 255,000$. The location is one of the most permanent to be found anywhere 
in the West, in a large valley whose drainage contains upward of $30,000,000,000$ feet of virgin timber. It can be fairly assumed, therefore, that the plant will have a life of at least 30 years, or a residual value at the end of the present operation of $\$ 85,000$.

The tract will be logged by railroad spurs extending from the end of the feeder up each of its three main watersheds. Three miles of main logging spur will develop the first watershed, which will furnish about four years' cut at 30,000,000 feet of logs annually. Three miles of main spur must then be constructed to the junction of the second and third watersheds, each of which will furnish about eight years' supply of logs. An extension of the main spur 9 miles up each of these streams will be necessary. Approximately 58 miles of branch spurs will be required on the three watersheds. These branches can, however, be operated with 8 miles of steel in continuous use. The logging will require, therefore, 3 miles of steel for the main logging spurs during the first four years, thereafter 12 miles; and 8 miles of steel for the branch spurs throughout the entire sale. Seventeen and one-half per cent of the timber, on agricultural lands which are to be cut clean, will be logged by steam machinery. The rest will be logged with horses. Woods improvements will consist of trail chutes and a few short pieces of flumie.

The investments required in the operation, aside from the tap line and mill site, are summarized in the following table:

Summary of Investments.

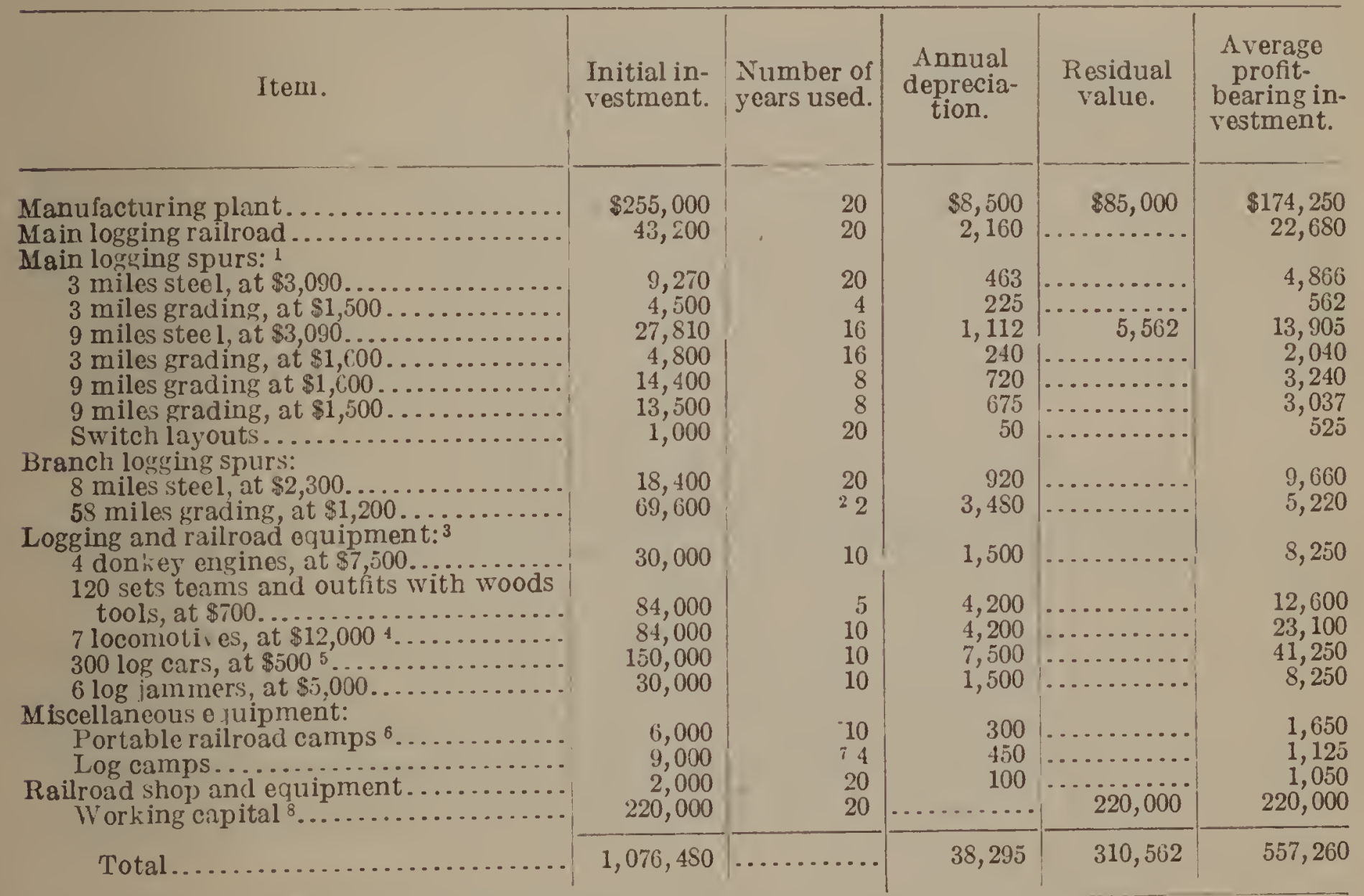

1 All items for railroad steel and iron are depreclated at 5 per cent annually.

2 Two years is the average period of use of each spur grade.

3 The initial investments include replacements throughout the life of the sale. Logging machinery, locomotices, and rolling stock depreciate completely in 10 years; lience double the average stock in use at any given time is figured. Teams and tools depreciate completely in 5 years; henco four times the average

stock is prorided for.
1 Three locomotives will be sufficient for the first 10 years; for the last 10 years four will be needed.

T This is based upon log transportation for the entire distance over tap line and present ra ilroad to the manufacturing plant, requiring 150 cars in continuous use.

6 Two complete sets, at $\$ 3,000$ each and each lasting 10 years, are provided for.

7 Four years is the average period of use of the log camps. out on hand. This has a cost value, excluding depreciation about one-third of the annual cut must be kept on hand. and profit and including an assumed average stumpage pr ice that an average supply of $3,000,000$ feet of logs (taking the lower schedule of costs, p. 59). It is also figured that an a read of railroading in the woods. should be kept ahead of cutt ing at the mill, and 2,000,000 feet of logs ahead of rail included in each case. The cost value of the former is $\$ 7.59$, and of the latter, $\$ 5$. Thivalent to one month's sales, $2,500,000$ feet, at a

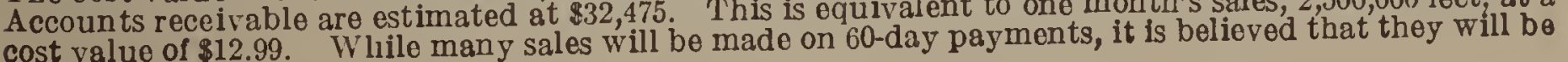


This operation involves the development of a manufacturing and logging industry in an entirely new region and the exploitation of a chance now wholly inaccessible. Risks beyond the ordinary are involved in:

1. Climatic conditions, no large operation s or extensive construction work having been conducted heretofore in these mountains.

2. Acquisition of additional timber to carry two-fifths of the investment in the main logging railroad.

3. Working out successfully the main transportation problem which involves (1) satisfactory traffic and log haul agreements with an established common carrier, and (2) enlisting other capital to construct the tap line or developing outside traffic to carry the tap line if built as part of the lumbering plant.

Under these conditions a return of 20 per cent annually on the invested capital is deemed equitable and necessary to place the chance upon the market.

With an average investment of $\$ 557,260$, the annual charge for profit is thus $\$ 111,452$; or, on an annual cut of $30,000,000$ feet, $\$ 3.68$ per 1,000 feet. The annual charge for depreciation is $\$ 1.27$ per 1,000 leet.

The logging costs are summarized as follows:

Stump to upper terminus of tap line.

\begin{tabular}{|c|c|c|c|c|c|c|}
\hline Item. & C. & M. & G. & $\mathrm{T}$ & $\mathrm{R}$. & Total. \\
\hline 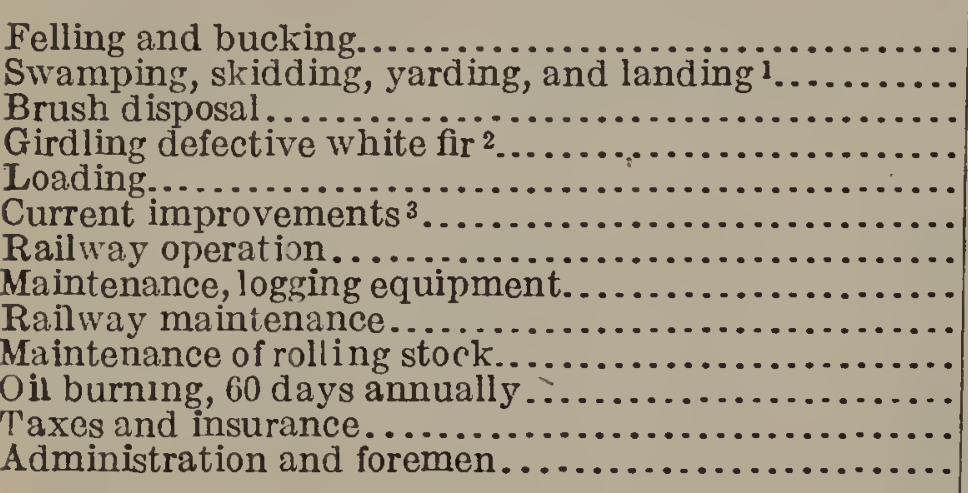 & 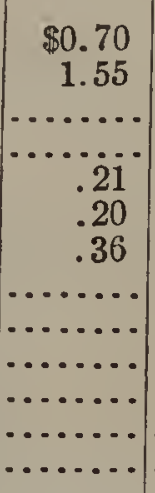 & $\begin{array}{r}\$ 0.11 \\
.27 \\
.10 \\
\cdots \ldots . \\
\cdots \ldots \ldots \\
\cdots \ldots\end{array}$ & $\$ 0.40$ & $\begin{array}{c}\$ 0.15 \\
\ldots \ldots \ldots\end{array}$ & 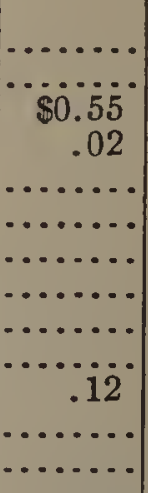 & $\begin{array}{r}\$ 0.70 \\
1.55 \\
.55 \\
.02 \\
.21 \\
.20 \\
.36 \\
.11 \\
.27 \\
.10 \\
.12 \\
.15 \\
.40\end{array}$ \\
\hline Total... & 3.02 & .48 & .40 & .15 & .69 & 4.74 \\
\hline
\end{tabular}

1 Based upon $17 \frac{1}{2}$ per cent power logging at $\$ 1.22$ and $82 \frac{1}{2}$ per cent horse logging at $\$ 1.63$.

2 This is a special silvicultural requirement proposed for the sale area.

3 This charge covers trail chutes, flumes, landings, and other current improvements aside from railroad grades, which are provided for under fixed investments.

The cost of manufacture and sales, exclusive of depreciation, has been averaged for a number of large mills in the Inland Empire similar to the proposed plant at $\$ 4.50$ per thousand feet lumber tally. Mill scale studies conducted at these plants indicate that 20 per cent is a conservative figure for overrun under Forest Service scaling in this class of timber. The milling charge per thousand feet log scale is thus $\$ 4.50 \times 1,200$, or $\$ 5.40$.

offset by an equi ialent amount of cash business. The a rerage outstanding deposit for stumpage is put at $\$ 5,000$; and the average amount required as a margin to meet contingencies at $\$ 20,000$. These items are then:

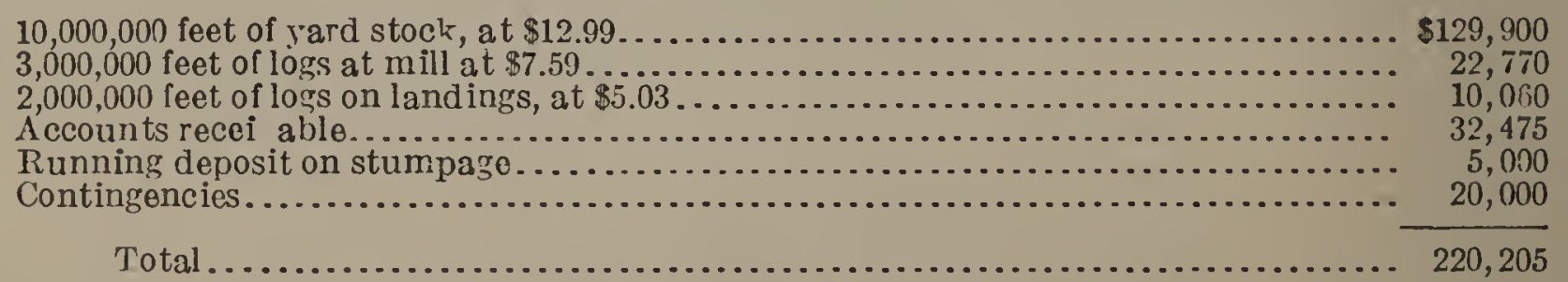

This may be checked from the total yearly operating cost and frequency of turn. The cost of the year's cut, exclusi i o depreciation and profit, is $\$ 389,700(30,000,000$ at $\$ 12.99)$. This would indicate an a verage turn of about seven months - which is liberal but not excessive for a large operation of this nature. 
If the appraisal is based upon the assumption that the tap line can be constructed practically as a common carrier independent of the lumbering operation, the only other charges to be taken into account are for freight on logs to the manufacturing plant, aggregating $\$ 1.35$ per thousand feet log scale.

If it is assumed that the tap line must be built by the lumbering company as part of the operation, under the conditions above stated, additional charges are necessary, as follows:

Profit on portion of tap line investment ${ }^{1} \ldots \ldots \ldots \ldots \ldots \ldots \ldots \ldots \$ 0.61$

Depreciation of additional rolling stock required $2 \ldots \ldots \ldots \ldots . . .08$

Profit on average investment in additional rolling stock ${ }^{2} \ldots \ldots \ldots . .09$

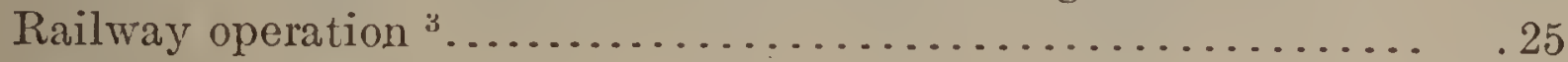

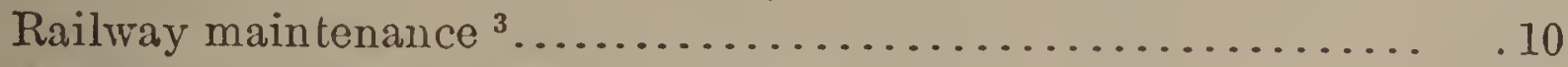

Maintenance of additional rolling stock................ .04

Total................................ 1.17

The charge for $\log$ freight from the end of this tap line to the mill is $\$ 80$ per $\mathrm{M}$ feet in any event.

Profit and production cost, exclusive of stumpage price, may then be summarized as follows:

\begin{tabular}{|c|c|c|}
\hline & $\begin{array}{l}\text { With tapline } \\
\text { as part of } \\
\text { operation. }\end{array}$ & $\begin{array}{l}\text { With tap line } \\
\text { as independ- } \\
\text { ent eommon } \\
\text { earrier. }\end{array}$ \\
\hline 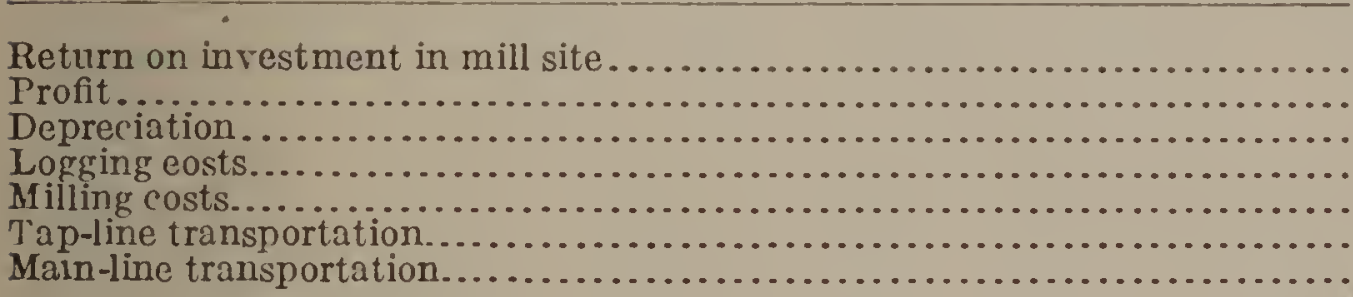 & $\begin{array}{r}\$ 0.08 \\
3.68 \\
1.27 \\
4.74 \\
5.40 \\
1.17 \\
.80\end{array}$ & $\begin{array}{r}\$ 0.08 \\
3.68 \\
1.27 \\
4.74 \\
5.40 \\
.55 \\
.80\end{array}$ \\
\hline & 17.14 & 16.52 \\
\hline
\end{tabular}

Where different methods of handling the main transportation problem should be considered, as is frequently the case in inaccessible chances, it is desirable for the appraiser to present the cost data under each. In this instance the choice obviously lies between a more and a less conservative policy as to whether the sale of National Forest stumpage sliould await the general economic development of the region or whether the Government timber should itself carry the principal burden of such development. Ordinarily the more conservative policy will be followed under such conditions. Stumpage prices will be based, therefore, upon the lower schedule of costs.

The average lumber value of the white-pine timber on the tract has been determined from three tables, which follow. The first gives, for sound timber, the average value by grades of stumpage of varying size, as indicated by the number of $\log s$ per thousand feet.

$1 \$ 18,360$ prorated annually over $30,000,000$ feet. (See p. 56. )

2 ' he additional equipment required is 2 engines in eurrent use. Their depreeiation, at 10 per eent annually, and average investment are figured as $\$ 2,400$ and $\$ 13,200$, respeetively. Profit on the latter figure is allowed at 20 per eent.

'These are the estimated proportions of the total eosts of operation and maintenanee ehargeable to the timber. (See p. 56.) 
Sound White Pine.

\begin{tabular}{|c|c|c|c|c|c|c|c|}
\hline \multirow{3}{*}{ Grade. } & \multirow{3}{*}{$\begin{array}{l}\text { Grade } \\
\text { value per } \\
\text { thousand. }\end{array}$} & \multicolumn{6}{|c|}{ Logs per thousand. } \\
\hline & & \multicolumn{2}{|c|}{18} & \multicolumn{2}{|c|}{6} & \multicolumn{2}{|c|}{3} \\
\hline & & $\begin{array}{l}\text { Per cent } \\
\text { of grado. }\end{array}$ & $\begin{array}{c}\text { Propor- } \\
\text { tional } \\
\text { value. }\end{array}$ & $\begin{array}{l}\text { Per cent } \\
\text { of grade. }\end{array}$ & $\begin{array}{c}\text { Propor- } \\
\text { tional } \\
\text { value. }\end{array}$ & $\begin{array}{l}\text { Per cent } \\
\text { of grade. }\end{array}$ & $\begin{array}{l}\text { Propor- } \\
\text { tional } \\
\text { value. }\end{array}$ \\
\hline 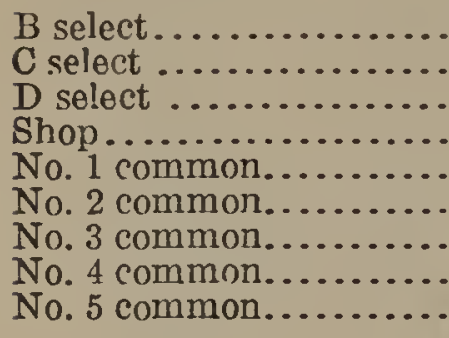 & $\begin{array}{r}\$ 4.5 .00 \\
38.00 \\
27.00 \\
20.00 \\
25.00 \\
21.00 \\
15.00 \\
11.00 \\
6.00\end{array}$ & $\begin{array}{r}0.14 \\
1.97 \\
3.72 \\
.43 \\
47.20 \\
21.73 \\
21.03 \\
3.66 \\
.12\end{array}$ & $\begin{array}{r}\$ 0.06 \\
.75 \\
1.00 \\
.09 \\
11.80 \\
4.56 \\
3.15 \\
.40 \\
.01\end{array}$ & $\begin{array}{r}1.57 \\
6.10 \\
8.88 \\
7.91 \\
29.92 \\
18.40 \\
22.18 \\
4.85 \\
.19\end{array}$ & $\begin{array}{r}\$ 0.71 \\
2.32 \\
2.40 \\
1.58 \\
7.48 \\
3.86 \\
3.33 \\
.53 \\
.01\end{array}$ & $\begin{array}{r}12.26 \\
12.67 \\
9.29 \\
24.41 \\
15.19 \\
9.09 \\
14.97 \\
2.07 \\
.05\end{array}$ & $\begin{array}{r}\$ 5.52 \\
4.81 \\
2.51 \\
4.88 \\
3.80 \\
1.91 \\
2.25 \\
.23 \\
\end{array}$ \\
\hline Total ... & & 100 & 21.82 & 100 & 22.22 & 100 & 25.91 \\
\hline
\end{tabular}

The second table gives similar data for defective white pine.

Defective White Pine.

\begin{tabular}{|c|c|c|c|c|c|c|c|}
\hline \multirow{3}{*}{ Grade. } & \multirow{3}{*}{$\begin{array}{l}\text { Grade } \\
\text { value per } \\
\text { thousand. }\end{array}$} & \multicolumn{6}{|c|}{ Logs per thousand. } \\
\hline & & \multicolumn{2}{|c|}{15} & \multicolumn{2}{|c|}{10} & \multicolumn{2}{|c|}{4} \\
\hline & & $\begin{array}{l}\text { Per cent } \\
\text { of grade. }\end{array}$ & $\begin{array}{c}\text { Propor- } \\
\text { tional } \\
\text { value. }\end{array}$ & $\begin{array}{l}\text { Per cent } \\
\text { of grade. }\end{array}$ & $\begin{array}{c}\text { Propor- } \\
\text { tional } \\
\text { value. }\end{array}$ & $\begin{array}{l}\text { Per cent } \\
\text { of grade. }\end{array}$ & $\begin{array}{c}\text { Propor- } \\
\text { tional } \\
\text { value. }\end{array}$ \\
\hline $\begin{array}{l}\text { B select......... } \\
\text { C select.......... } \\
\text { D select......... } \\
\text { Shop .......... } \\
\text { No. } 1 \text { common.. } \\
\text { No. } 2 \text { common.. } \\
\text { No. } 3 \text { common.. } \\
\text { No. } 4 \text { common.. } \\
\text { No. } 5 \text { common.. }\end{array}$ & $\begin{array}{r}\$ 45.00 \\
38.00 \\
27.00 \\
20.00 \\
25.00 \\
21.00 \\
15.00 \\
11.00 \\
6.00\end{array}$ & $\begin{array}{r}0.91 \\
3.52 \\
7.17 \\
.21 \\
18.23 \\
15.38 \\
28.24 \\
23.77 \\
2.57\end{array}$ & $\begin{array}{r}\$ 0.41 \\
1.34 \\
1.94 \\
.04 \\
4.56 \\
3.23 \\
4.24 \\
2.61 \\
.15\end{array}$ & $\begin{array}{r}0.93 \\
7.85 \\
11.32 \\
1.83 \\
14.12 \\
6.94 \\
27.85 \\
25.28 \\
3.88\end{array}$ & $\begin{array}{r}\$ 0.42 \\
2.99 \\
3.06 \\
.37 \\
3.53 \\
1.46 \\
4.18 \\
2.78 \\
.23\end{array}$ & $\begin{array}{r}10.94 \\
11.60 \\
11.60 \\
9.87 \\
4.68 \\
3.77 \\
19.21 \\
22.41 \\
5.92\end{array}$ & $\begin{array}{r}\$ 4.92 \\
4.41 \\
3.13 \\
1.97 \\
1.17 \\
.79 \\
2.88 \\
2.47 \\
.36\end{array}$ \\
\hline Total. & & 100 & 18.52 & 100 & 19.01 & 100 & 22.10 \\
\hline
\end{tabular}

The third table sets forth the run of the white-pine stumpage on the chance, by size classes of sound and defective timber, respectively, with the average cut of grades and grade values.

Grades and Grade Values of White Pine.

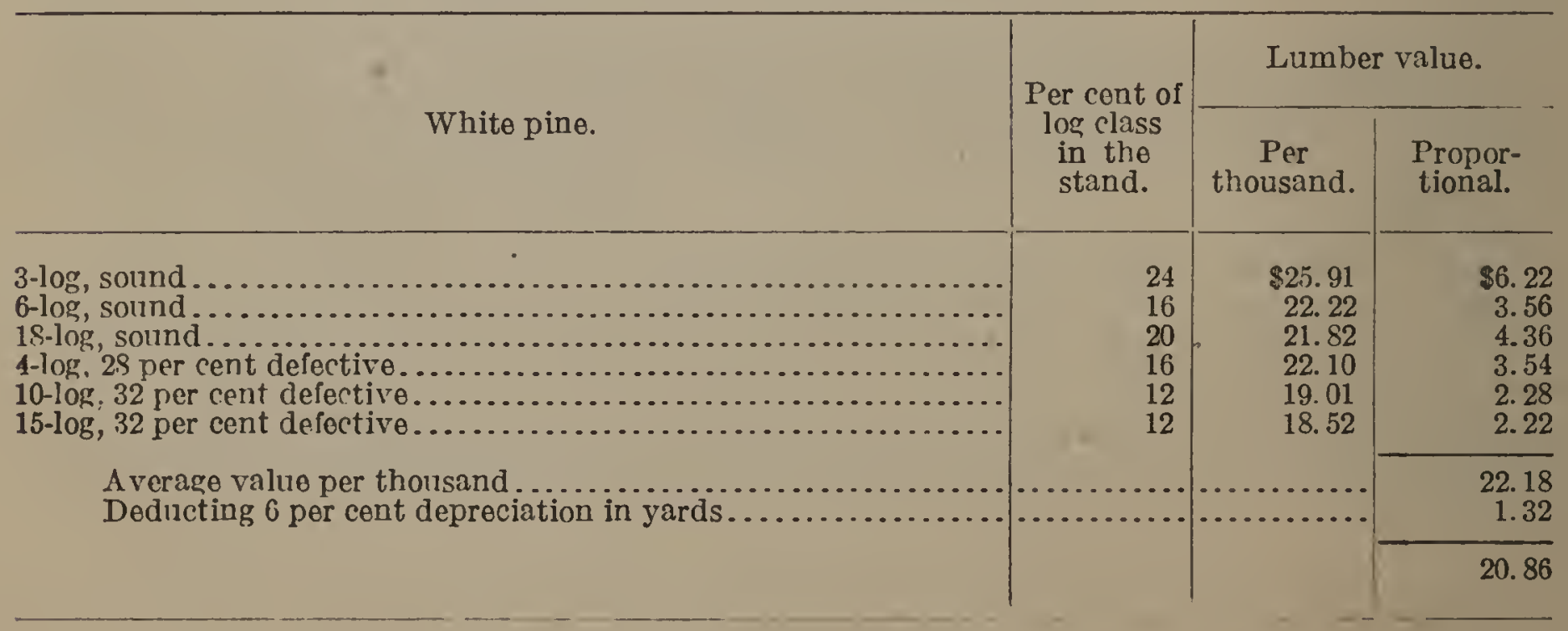


The mill-run prices of the other species have been similarly determined, as follows:

Yellow pine. $\$ 16.87$

Lodgepole pine

Engelmann spruce

White fir...

Larch, Douglas fir, and cedar.

12.00

In determining the total value of each species $\log$ scale, it is figured that in addition to an overrun of 20 per cent a net return of 40 cents per thousand feet will be obtained for white, yellow, and lodgepole pine from the manufacture of lath and a net return of 30 cents per thousand feet for all species from the sale of slab wood and mill waste. The log-scale values of the respective species are therefore:

White pine, $\$ 20.86$, extended for 20 per cent overrun ....... \$25.03

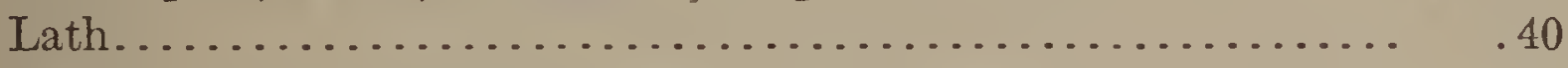

Slab wood and mill waste $\ldots \ldots \ldots \ldots \ldots \ldots \ldots \ldots \ldots \ldots \ldots . \quad .30$

Yellow pine, $\$ 16.87$, extended for 20 per cent overrun....... $\overline{\overline{20.24}}$

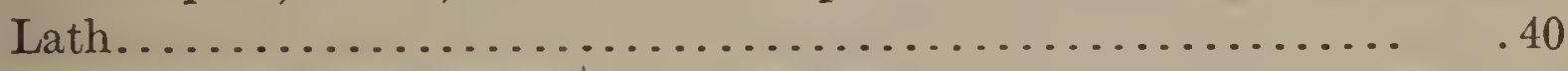

Slab wood and mill waste $. . . \ldots \ldots \ldots \ldots \ldots \ldots \ldots \ldots \ldots \ldots . \quad .30$

20.94

Lodgepole pine, $\$ 15$, extended for 20 per cent overrun....... 18.00

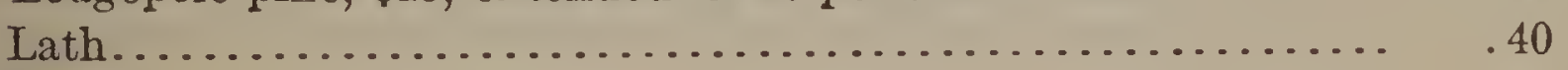

Slab wood and mill waste $. . \ldots \ldots \ldots \ldots \ldots \ldots \ldots \ldots \ldots \ldots . \quad .30$

18. 70

Engelmann spruce, $\$ 14$, extended for 20 per cent overrun...... 16.80

Slab wood and mill waste $\ldots \ldots \ldots \ldots \ldots \ldots \ldots \ldots \ldots \ldots \ldots . . \quad .30$

17. 10

White fir, $\$ 13$, extended for 20 per cent overrun.......... $\overline{15.60}$

Slab wood and mill waste ........................ $\quad .30$

15.90

Larch, Douglas fir, and cedar, $\$ 12$, extended for 20 per cent

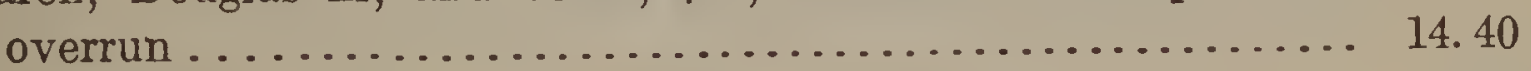

Slab wood and mill waste $\ldots \ldots \ldots \ldots \ldots \ldots \ldots \ldots \ldots \ldots \ldots . \quad .30$

14.70

If the total charge for profit and depreciation, $\$ 5.03$ per thousand feet, be prorated on the margin between operating costs and selling price of the respective species, in accordance with the method discussed on page $45,{ }^{1}$ the following stumpage prices are obtained:

White pine............... \$3.56 Engelmann spruce........... \$1.41

Yellow pine................. 2.36 White fir................. 1.11

Lodgepole pine............... 1.81 Other species............... 81

1 The average margin is $\$ 6.63$ (average selling price, $\$ 18.12$, less the operating costs, $\$ 11.49$ ). $\frac{\$ 5.03}{\$ 6.63}=\$ 0.75$ to be taken for each dollar of margin to make up profit and depreciation. With this figure and the difference between operating costs and the selling price of each species, the stumpage rates are readily derived. 


\section{EXAMPLES OF THE OVERTURN METHOD.}

In the three examples following the overturn method of computing profit has been used.

\section{SMALL SHORTLEAF-PINE OPERATIONS IN ARKANSAS.}

In this region logging is easy and readily contracted at established rates. A great deal of milling business is done on small capital. Current bids indicate that relatively low profits are satisfactory to the operators.

The chance is estimated to contain 20,000,000 feet, to be cut in five years. The timber will be logged to small, portable mills for sawing; then dried in "smoke kilns" for several days; thence hauled to a point on a common-carrier railway at which the operator's finishing plant is located. Logging conditions are very similar over the entire tract, but the chance is divided into five operating units, because of the different lengths of haul from mill to rail. Hauling distance is the determining factor in fixing stumpage rates.

Logging operations in this region are very simple, because of the rough country and thin, scattered stands. The timber runs from $1 \frac{1}{2}$ to $2 \frac{1}{2}$ (rarely 3 ) logs per tree and from 8 to 10 logs per thousand feet. It is very sound, less than 10 per cent of the logs showing any defect.

Small portable sawmills, cutting from 8,000 to 16,000 feet per day and costing from $\$ 1,200$ to $\$ 3,000$ each, are set up in "hollows" or narrow valleys, where from 600,000 to 2,000,000 feet of logs can be brought in by wagon haul. Log haul to the mill sites for the area as a whole seldom exceeds 3 miles, and the average haul is $1 \frac{1}{2}$ miles.

Logging and milling costs in the region are very uniform and easily standardized. Felling, bucking, and brush disposal is usually contracted at $\$ 1$ per thousand feet, the cutters furnishing their own tools, oil, etc. Bunching logs, loading on wagons, and hauling to the mill is done either by contract or with the operator's teams. Contract rates are usually $\$ 1.25$ for the first quarter mile and 25 cents for each additional quarter mile, this price including what little road building is necessary, which may cost $\$ 30$ per mile. A 1-mile haul thus costs $\$ 2$ by contract, and an average haul of $1 \frac{1}{2}$ miles $\$ 2.50$, four to five trips per day being made at that distance, with from 250 to 350 feet per team. The price is so based as to allow the contractor from $\$ 3$ to $\$ 3.50$ per day for himself, wagon, rigging, and two mules; hence it is not certain that the cost of contracting can be reduced if the operator logs his own timber.

Nine or ten men are employed at the sawmill, cutting as many thousand feet a day. As an average for 5 miles examined cutting from six to sixteen thousand feet per day, wages aggregate $\$ 1.50$ per thousand feet. This includes piling in the smoke kilns, where most of the lumber stays about a week before hauling.

Lumber is cut a little scant, so that 2-inch lumber when seasoned measures $1_{\frac{3}{4}}^{\frac{3}{4}}$ inches and inch stock about thirteen-sixteenths. On account of the long lumber haul, No. 3 common boards are not saved, but burned with the slabs and edgings. Under these conditions the cut of No. 2 and better grades was found to overrun log scale by 5 to 10 per cent, but this overrun is almost wholly lost by shrinkage at the planer.

Iumber is hauled to rail by contract, at $\$ 2$ for a 7 to 8 mile haul, $\$ 3$ for an 11 or 12. mile haul, $\$ 3.50$ for a 14-mile haul, and $\$ 1$ for an 18 -mile haul. The roads are hilly, but otherwise fairly good except in wet weather. A team will haul 900 to 1,100 feet of half-dried lumber 12 miles and return in a day.

The investments required to cut this body of $20,000,000$ feet in five years may be tabulated as follows: 


\begin{tabular}{|c|c|c|c|c|c|}
\hline Item. & $\begin{array}{c}\text { Initial } \\
\text { investment. }\end{array}$ & $\begin{array}{l}\text { Number } \\
\text { of years } \\
\text { used. }\end{array}$ & $\begin{array}{l}\text { Annual } \\
\text { deprecia- } \\
\text { tion. }\end{array}$ & $\begin{array}{l}\text { Residual } \\
\text { value. }\end{array}$ & $\begin{array}{c}\text { A verage } \\
\text { profit- } \\
\text { bearing } \\
\text { investment. }\end{array}$ \\
\hline 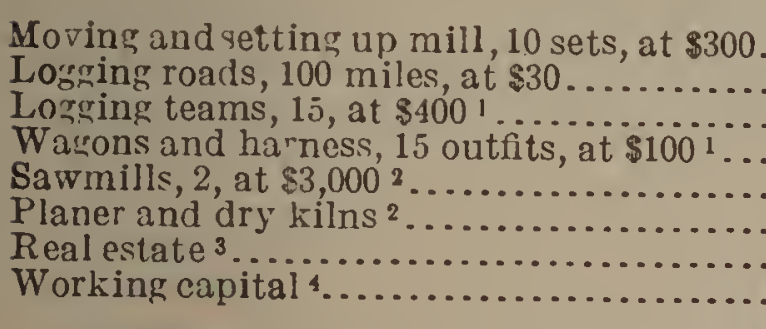 & $\begin{array}{r}\$ 3,000 \\
3,000 \\
6,000 \\
1,500 \\
6,000 \\
8,000 \\
2,000 \\
4,500 \\
\end{array}$ & $\begin{array}{l}1 \\
1 \\
5 \\
5 \\
5 \\
5 \\
5 \\
5\end{array}$ & $\begin{array}{r}\$ 600 \\
600 \\
900 \\
225 \\
420 \\
560\end{array}$ & $\begin{array}{r}\$ 1,500 \\
375 \\
3,900 \\
5,200 \\
2,000 \\
4,500 \\
\end{array}$ & $\begin{array}{r}\$ 600 \\
600 \\
4,200 \\
1,050 \\
5,110 \\
6,880 \\
2,000 \\
4,500\end{array}$ \\
\hline Total. & 31,000 & & 3,305 & 17,475 & 24,990 \\
\hline
\end{tabular}

1 Depreciated at 15 per cent annually.

2 Depreciated at 7 per cent annually.

I Ixclusive of residence, store, and small farms, which are self-sustaining.

Consists of lumber at planer, $\$ 3,000$, and lumber at sawmills, $\$ 1,500$. Otherwise the turn is sumciently quick to pay operating costs directly from sales of the product. NotE.-One year is taken as the average period of use of the money required for mill sets and logging
roads.

The production costs, figuring an annual cut of $4,000,000$ feet, are:

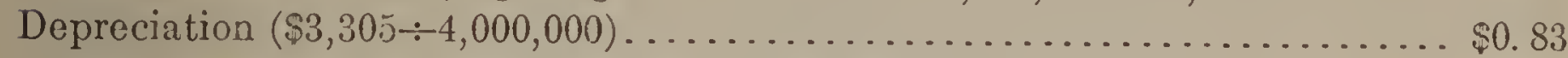

Felling, bucking, and brush disposal, contract price.............. 1.00

Team maintenance and labor, bunching and hauling to mill .......... 2.00

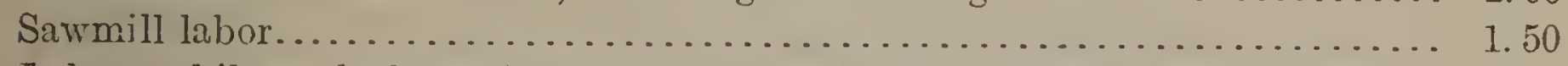

Labor at kiln and planer (labor of 15 men, $\$ 26.25$, to plane, run through dry kiln, and load, prorated on 20,090$) \ldots \ldots \ldots \ldots \ldots \ldots \ldots \ldots \ldots \ldots \ldots \ldots \ldots \ldots \ldots . .32$

Taxes and insurance (annual amounts-\$400 and $\$ 500$, respectively) ..... . $22 \frac{1}{2}$

General expense.............................................. $73 \frac{1}{2}$

(The total annual amounts are: Supplies and repairs, $\$ 450$; superintendent,

$\$ 1,200$; bookkeeper, \$900; general office expenses, \$390.)

Total production cost, exclusive of stumpage and lumber haul..... 7.61

The average cost of the lumber haul, from planer to rail, 1 \$3 per thousand feet. The net price of the lumber at the shipping point has a veraged $\$ 16$ per thousand feet for the past 15 months. The profit on overturn is put at 23 per cent, which corresponds with the general returns from such operations in the region. The average stumpage price is thus $\$ 16-\$ 10.61-\$ 1.23(\$ 10.61)$, or $\$ 2.95$. This gives the operator a profit of $\$ 2.44$ per thousand feet, or a gross annual retum of $\$ 9,760$. It is equivalent to a return of 39 per $t$ on the a verago investment.

The stumpage price may be adjusted approximately between the several units in the chance, to provide for variations in the cost of lumber haul, as follows:

\begin{tabular}{|c|c|c|c|c|c|}
\hline Item. & Unit $A$. & Unit B. & Unit C. & Unit D. & Unit E. \\
\hline 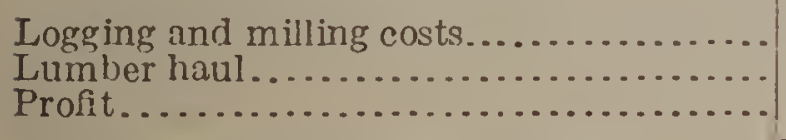 & $\begin{array}{r}\$ 7.61 \\
3.50 \\
2.44\end{array}$ & $\begin{array}{r}\$ 7.61 \\
3.50 \\
2.44\end{array}$ & $\begin{array}{r}\$ 7.61 \\
2.50 \\
2.44\end{array}$ & $\begin{array}{r}\$ 7.61 \\
3.75 \\
2.44\end{array}$ & $\begin{array}{r}\$ 7.61 \\
2.50 \\
2.44\end{array}$ \\
\hline 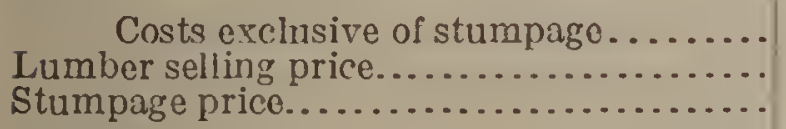 & $\begin{array}{r}13.5 .5 \\
16.00 \\
2.45\end{array}$ & $\begin{array}{r}13.55 \\
16.00 \\
2.45\end{array}$ & $\begin{array}{r}12.55 \\
16.00 \\
3.45\end{array}$ & $\begin{array}{r}13.80 \\
16.00 \\
2.20\end{array}$ & $\begin{array}{r}12.55 \\
16.00 \\
3.45\end{array}$ \\
\hline
\end{tabular}

\section{A IOGGER'S SALE IN NOR'THFIRN MONTANA.}

A chance on a drivable stream tributary to the Kootenai River contains 14,000,000 feet, running 76 per cent yellow pine, 16 per cent western larch, and 8 per cent Dougias fir. The timber averages from three to four logs to the tree and eight logs to the thousand fect. The season of high water is short and no satisfactory drive can be handled without cleaning about 6 miles of stream bed and constructing two sulash dams. The stream has never been driven before. With these improvements, it will be practicable 
to drive from two to four million feet annually 6 miles to the Kootenai River. The operation will, therefore, extend over four logging seasons.

About one-fourth of the timber can be skidded directly from the stump to the landings. Another fourth can be drayed to the creek over an average distance of $1 \frac{1}{2}$ miles. Where topography is suitable, logs will be skidded short distances to chutes and handled through them to the creek. Approximately 30 per cent of the timber will be logged in this way. The rest, on account of uphill slopes, must be loaded on sleds and hauled to the landings.

The following investments will be required:

\begin{tabular}{|c|c|c|c|c|c|}
\hline Item. & $\begin{array}{c}\text { Initial } \\
\text { investment. }\end{array}$ & $\begin{array}{l}\text { Number } \\
\text { of years } \\
\text { used. }\end{array}$ & $\begin{array}{l}\text { Annual } \\
\text { deprecia- } \\
\text { tion. }\end{array}$ & $\begin{array}{l}\text { Residual } \\
\text { value. }\end{array}$ & $\begin{array}{c}\text { Average } \\
\text { profit- } \\
\text { bearing } \\
\text { investment. }\end{array}$ \\
\hline 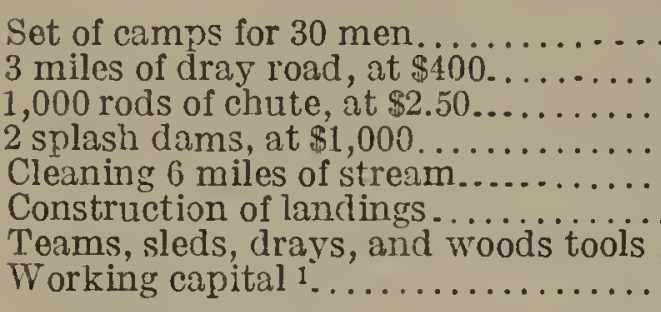 & $\begin{array}{r}\$ 1,500.00 \\
1,200.00 \\
2,500.00 \\
2,000.00 \\
1,500.00 \\
500.00 \\
5,000.00 \\
8,000.00\end{array}$ & $\begin{array}{l}4 \\
2 \\
2 \\
4 \\
4 \\
2 \\
4 \\
4\end{array}$ & $\begin{array}{r}\$ 375.00 \\
300.00 \\
625.00 \\
500.00 \\
375.00 \\
125.00 \\
500.00\end{array}$ & $\begin{array}{r}\$ 3,000.00 \\
8,000.00\end{array}$ & $\begin{array}{r}\$ 937.50 \\
450.00 \\
937.50 \\
1,250.00 \\
937.50 \\
187.50 \\
4,250.00 \\
8,000.00\end{array}$ \\
\hline Total. & $22,200.00$ & & $2,800.00$ & $11,000.00$ & $16,950.00$ \\
\hline
\end{tabular}

1 The logging season covers 5 months, from Nov. 1 to Apr. 1. Logging costs, exclusive of breaking rollways and driving, total $\$ 3.02$, and the stumpage prico is assumed to be $\$ 2$. The average cut is 700,000 feet of logs per month, involving a cost for stumpage and logging of $\$ 3,514$. It is figured that sufficient canital must be furnished to run the camp 2 months, or $\$ 7,028$, with a margin of $\$ 1,000$ for contingencies. The logs aro delivered in Kootenai River and paid for in May. Driving charges and logging costs for the last 3 months of the season can usually be carried on the operator's books until the logs are sold. Often, indeed, contracts are made under which part payment is advanced on the scale of the logs in rollways.

Logging costs are summarized as follows:

Depreciation of fixed investments $(\$ 2,800 \div 3,500,000)$ $\$ 0.80$

Felling and cutting, by contract.................... $\quad .70$

Swamping................................. 40

Brush disposal..................................... . 25

Skidding...........................................

Chuting, draying, and hauling ....................... 40

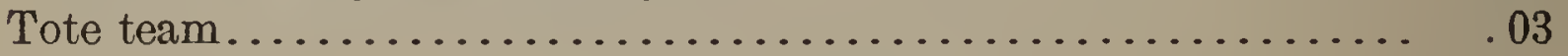

Horse feed.............................. 15

Blacksmithing and repairs........................... 14

Decking in rollways........................... 30

Breaking rollways................................ 15

Driving to Kootenai River......................... . 30

General expense, clerk, etc..................... $\quad .20$

Total.................................. 4.27

The current log price for mixed runs of these species on Kootenai River is $\$ 7.50^{1}$ per thousand feet. The cost of driving downstream 25 miles to a large going mill, which forms the only available market, and booming is $\$ 1$ per thousand feet. The standard manufacturing cost at this plant, including depreciation on mill and equipment, is $\$ 5$ per thousand feet, lumber tally. The normal overrun in this timber is 20 per cent. This is reduced, however, by loss in driving and storage, to 12 per cent.

The average mill-run lumber selling prices are $\$ 15$ for yellow pine and $\$ 12$ for larch and Douglas fir, or for the chance:

Yellow pine, 76 per cent, at $\$ 15 \ldots \ldots \ldots \ldots \ldots \ldots \ldots \ldots \ldots \ldots \ldots \ldots \ldots . . . \ldots$

Larch and fir, 24 per cent, at $\$ 12 \ldots \ldots \ldots \ldots \ldots \ldots \ldots \ldots \ldots . . .68$

Average price.............................. 14.28

I In this instance, however, the manufacturers furnish a part of the capital required bs tho loggers, which has the effect of an increase in the log price. 
Fifteen per cent profit on overturn is equitable for the cost of the main river drive and of manufacturing. Aside from loss in driving, the risk, at this large, welldeveloped plant, is comparatively slight. On the other hand, a profit of 35 per cent on overturn is deemed but fair to the logger, whose entire success depends upon the development and use of a stream hitherto undriven.

Using the overturn formula which provides separate rates of profit for logging and manufacturing, the stumpage price is determined as follows:

$$
\begin{gathered}
X=\$ 15.99^{1}-\$ 4.27-.35(\$ 4.27)-\$ 1-\$ 5.60^{1}-.15(\$ 1+\$ 5.60) . \\
X=\$ 2.64 .
\end{gathered}
$$

The logger's profit, as thus computed, is 35 per cent of $\$ 4.27$, or $\$ 1.49$. The manufacturer's profit is 99 cents.

At the prevailing log market the logger's profit would be $\$ 7.50-(4.27+2.64)$, or 59 cents, a rate on the overturn of 14 per cent. This indicates that the appraisal is high for the log market but equitable for the lumber market, allowing a total profit of $\$ 2.48$. The latter should govern the appraisal.

This operation is typical of small sales to loggers who sell their cut to large going mills. As in this instance, the log market is usually an unsafe basis for appraisal. Investments are small as a rule, particularly where stream driving is employed. Twenty-five per cent return on the average investment in this operation, using a high rate on account of the risks involved, would yield a profit of $\$ 1.21$ per thousand feet. Rarely will a straight investment return at the usual rates give an adequate logger's profit in such cases. If a return of 25 per cent on the average investment were supplemented by a supervisory charge for the personal services of the contractor, however, no such charge being included in the operating costs, a practicable margin would be afforded. In this instance the greater part of eight months each year is spent by the purchaser on the logging operation. A salary of $\$ 150$ per month as foreman would add $\$ 1,200$ a year, or 34 cents per thousand feet, to the returns from the enterprise. The total return thus realized, $\$ 1.55$, would make the sale a good logging proposition.

The alternative method of determining profit on manufacturing in sales of this character is as a percentage of the average investment in the milling plant and working capital required to run it, prorated over its total annual cut. The average milling investment in the case discussed may be put at $\$ 275,000$, with an average yearly cut, $\log$ scale, of $30,000,000$ board feet. A return of $12 \frac{1}{2}$ per cent on this mill investment may be regarded as equitable. This calls for an annual sum for profit of $\$ 34,375$, or $\$ 1.14$ per thousand feet of logs manufactured. In lieu of this figure, a standardized milling profit, found by experience to be generally applicable throughout the region, might be used.

\section{A SALE OF TIE AND MINING TIMBER IN WYOMING.}

A chance containing $60,000,000$ feet of lodgepole pine is to be cut out in five years.

\begin{tabular}{|c|c|c|c|}
\hline Product. & Amount. & $\begin{array}{l}\text { Per cent } \\
\text { of stand. }\end{array}$ & $\begin{array}{c}\text { Average } \\
\text { price. }\end{array}$ \\
\hline $\begin{array}{l}\text { Hewn railroad ties.. } \\
\text { Sawed ties.......... } \\
\text { Mine props........ } \\
\text { Lumbor }{ }^{3} . . . . . . .\end{array}$ & $\begin{array}{l}518,400 \text { pieces. . . } \\
1,036,800 \text { pieces. } \\
720,000 \text { pioces. . } \\
4,200,000 \text { feet. . }\end{array}$ & $\begin{array}{r}27 \\
54 \\
12 \\
7\end{array}$ & $\begin{array}{r}2 \$ 0.57 \\
.60 \\
.30 \\
18.00\end{array}$ \\
\hline
\end{tabular}
Its products, with their average selling prices delivered at the railroad, are as follows:

1 Selling price and milling cost are extended for 12 per cent overrun.

290 por cent standard, at $\$ 0.60 ; 10$ per cent seconds, at $\$ 0.30$.

Sido l inber only made in cutting sawed ties.

$60813-14-5$ 
The operation of the chance will require the construction of 27 miles of flume from the timber to a river in the main valley below the mountains, down which the ties and other products will be driven to a small storage and loading yard at the railroad. A dam must be built to form a storage reservoir on the sale area, into which the timber is delivered by branch flumes, and two additional dams to control the supply of water for the reservoir and flumes. A sawmill with a daily capacity of 50,000 feet will be built at the outlet of the reservoir to slab or saw the larger logs into ties with a small by-product of side lumber.

An old freight road running near the chance must be repaired and 12 miles of additional road built to reach all of the camp sites; 35 miles of telephone line are required, paralleling the flume, to connect the sawmill, headquarters camp, and flume camps with the office at the railroad. Unloading ground and storage yards at the latter point must be purchased at a cost of approximately $\$ 1,000$; and $\$ 1,200$ expended for a boom in the river and a jack-chain system to land the ties and other timbers in the yards. Office buildings will, however, be rented. Horse skidding and sled hauling to the reservoir or branch flumes will be employed exclusively.

The commissary and store which will be maintained at the headquarters camp are not included in the appraisal. (See p. 13.) This enterprise, including the construction of the buildings used, the furnishing and hauling of supplies, and the employment of a cook and storekeeper, is regarded as distinct from the timber sale. The seasons for various parts of the operation are:

Cutting, June 1 to January 31, eight months.

Skidding, July 1 to February 28, eight months.

Hauling, November 15 to March 15, four months.

Milling, May 15 to October 15, five months.

Fluming, May 15 to October 15, five months.

The investments necessary will be tabulated in the usual form.

\begin{tabular}{|c|c|c|c|c|c|}
\hline Item. & $\underset{\text { investment. }}{\text { Initial }}$ & $\begin{array}{l}\text { Number } \\
\text { of years } \\
\text { used. }\end{array}$ & $\begin{array}{l}\text { Annual } \\
\text { deprecia- } \\
\text { tion. }\end{array}$ & $\begin{array}{l}\text { Residual } \\
\text { value. }\end{array}$ & $\begin{array}{c}\text { A verage } \\
\text { profit } \\
\text { bearing } \\
\text { investment. }\end{array}$ \\
\hline 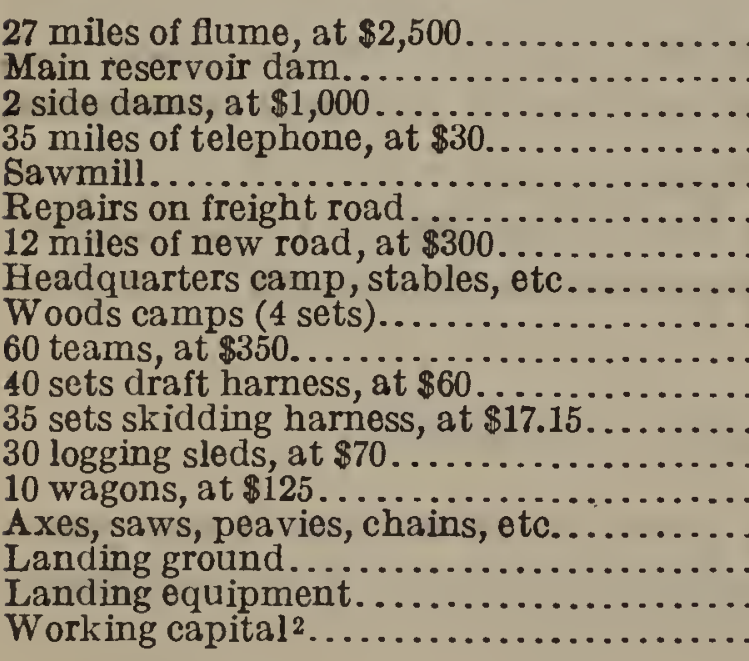 & $\begin{array}{r}\$ 67,500 \\
2,000 \\
2,000 \\
1,050 \\
20,000 \\
5,000 \\
3,600 \\
2,000 \\
2,000 \\
21,000 \\
2,400 \\
2,1000 \\
1,250 \\
3,000 \\
1,000 \\
1,200 \\
102,000\end{array}$ & $\begin{array}{r}5 \\
5 \\
5 \\
5 \\
5 \\
5 \\
14 \\
5 \\
13 \\
5 \\
5 \\
5 \\
5 \\
5 \\
5 \\
5 \\
5 \\
5\end{array}$ & $\begin{array}{r}\$ 13,500 \\
400 \\
400 \\
210 \\
2,000 \\
1,000 \\
720 \\
400 \\
400 \\
3,000 \\
320 \\
80 \\
210 \\
100 \\
360 \\
160\end{array}$ & $\begin{array}{r}\$ 10,000 \\
\cdots \cdots \\
\cdots \\
6,000 \\
800 \\
200 \\
1,050 \\
750 \\
1,200 \\
1,000 \\
400 \\
102,000\end{array}$ & $\begin{array}{r}\$ 40,500 \\
1,200 \\
1,200 \\
630 \\
16,000 \\
3,000 \\
1,800 \\
1,200 \\
800 \\
15,000 \\
1,760 \\
440 \\
1,680 \\
1,050 \\
2,280 \\
1,000 \\
880 \\
102,000\end{array}$ \\
\hline Total. . & 239,700 & & 23,260 & 123,400 & 192,420 \\
\hline
\end{tabular}

1 Each of the woods camps and branch roads to them will be in use but part of the total operation.

2 The calculation of working capital is given in detail on p. 68 . 
The operating costs for the various products are estimated as follows:

\begin{tabular}{|c|c|c|c|c|}
\hline Item. & $\begin{array}{l}\text { Hewn ties, } \\
\text { per piece. }\end{array}$ & $\begin{array}{c}\text { Sawed ties, } \\
\text { per piece. }\end{array}$ & $\begin{array}{c}\text { Mine props, } \\
\text { per piece. }\end{array}$ & $\begin{array}{l}\text { Lumber, } \\
\text { per } 1,000 \\
\text { feet. }\end{array}$ \\
\hline 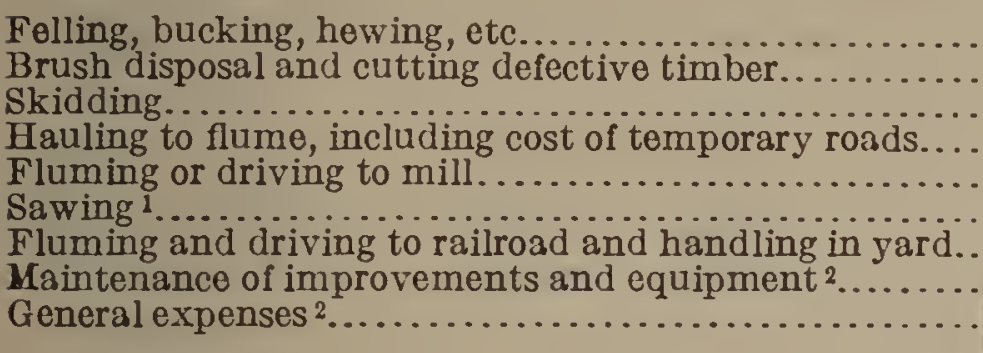 & $\begin{array}{r}\$ 0.122 \\
.030 \\
.050 \\
.040 \\
0.0 \\
.035 \\
.010 \\
.017\end{array}$ & $\begin{array}{l}\$ 0.031 \\
.024 \\
.031 \\
.056 \\
.016 \\
.055 \\
.035 \\
.013 \\
.022\end{array}$ & $\begin{array}{r}\$ 0.030 \\
.010 \\
.050 \\
.035 \\
\cdots .0 . \\
.025 \\
.005 \\
.009\end{array}$ & $\begin{array}{r}\$ 1.00 \\
.75 \\
1.00 \\
1.78 \\
.50 \\
2.50 \\
1.25 \\
.422 \\
.742\end{array}$ \\
\hline Total.. & .304 & .283 & .164 & 9.944 \\
\hline
\end{tabular}

1 No overrun can be figured on aecount of the large part of the logs eut into ties, which are dealt with separately by the piece, and the inability to flume and market short lengths and low grades.

2 Under these items there is charged against each product only the expenditures for upkeep of improvements and equipment, supervision, inspection, office costs, etc., applieable to that part of the operation.

The annual depreciation will be prorated over the net value of the year's cut; that is, the total margin between operating cost and selling price. This is:

\begin{tabular}{|c|c|c|c|}
\hline Product. & $\begin{array}{l}\text { Annual } \\
\text { cut. }\end{array}$ & $\begin{array}{l}\text { Margin } \\
\text { per unit. }\end{array}$ & $\begin{array}{c}\text { Total } \\
\text { margin. }\end{array}$ \\
\hline 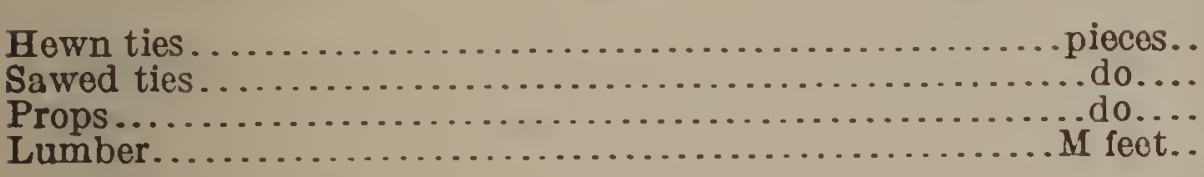 & $\begin{array}{r}103,680 \\
207,360 \\
144,000 \\
840\end{array}$ & $\begin{array}{r}\$ 0.266 \\
.317 \\
.136 \\
8.056\end{array}$ & $\begin{array}{r}\$ 27,578.88 \\
65,733.12 \\
19,584.00 \\
6,767.04\end{array}$ \\
\hline Total. & & & $119,663.04$ \\
\hline
\end{tabular}

The mill depreciation, $\$ 2,000$, should obviously be borne by the mill products, lumber and sawed ties, exclusively. The remaining depreciation, $\$ 21,260$, is chargeable to the entire cut. The depreciation charge for the several products is thus determined as follows:

For the sawmill $\frac{\$ 2,000}{\$ 72,500.16}=\$ 0.028$ perdollar of margin on lumber and sawed ties.

For other improvements and equipment $\frac{\$ 21,260}{\$ 119,663.04}=\$ 0.178$ per dollar of margin on the entire cut of all products.

Depreciation on lumber, per thousand feet.............. $\$ 1.66$

Depreciation on sawed ties, per piece................. .065

Depreciation on hewn ties, per piece................. $\quad .047$

Depreciation on props, per piece.................. .024

Adding depreciation to the operating costs, the total overturn for the respective products is:

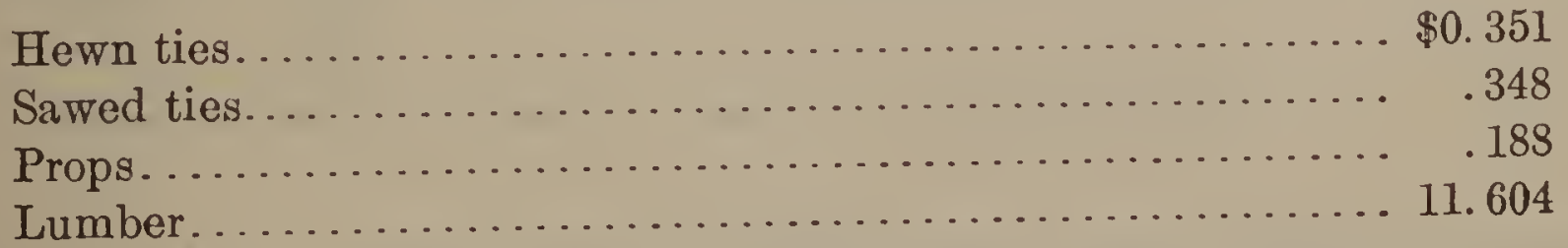

Twenty-five per cent of the overturn is believed to be a fair profit margin for hewn and sawed ties. These are contracted in advance in large quantities, are always in demand, and involve no market risk. The operation requires, however, an excep: tional amount of working capital and is subject to more than the ordinary logging risk on account of the possible shortage of water, delays in fluming, and hanging up 
of part of the year's cut. A profit margin of 35 per cent is deemed equitable on props and lumber. The market for this material is uncertain, and much of it must often be carried in the yards for considerable periods before it can be sold.

The stumpage prices are thus fixed as follows:

\begin{tabular}{c} 
Product. \\
\hline
\end{tabular}

The price of sawed ties is equivalent, at the ratio of 32 per thousand feet, to a log scale rate per thousand board feet of $\$ 5.31$. Since both sawed ties and lumber are manufactured from logs too large for hewing, their respective prices may be averaged in the ratio of 54 to 7 (per cents in the total cut) at $\$ 4.97$.

The large amount of working capital required on account of the limited fluming season adapts this chance to appraisal by the investment method more logically than by the overturn method. The need for a large working fund as well as considerable money for improvements makes the enterprise primarily capitalistic in nature. The requirements of the investment method would be met by a return of 20 per cent upon the average profit-bearing investment of $\$ 192,420$. Twenty per cent is regarded as an equitable margin under the risks indicated.

In estimating the working capital for this operation, it is assumed that the average date of delivering the year's cut at the railroad is August 1, the middle of the fluming season; and that wages are paid on the 15th of the month following that in which the work was done.

The working funds required for logging must cover cash payments for stumpage, labor, horse feed, maintenance, and general expense throughout the cutting, skidding, and hauling seasons and carry these payments until the following August 1. The various expenditures may be tabulated by dates as follows, the number of months elapsing between each payment and the date of delivery being indicated:

\begin{tabular}{|c|c|c|c|c|c|c|c|c|}
\hline & Date. & Stumpage. & Labor. & Horse feed. & $\begin{array}{c}\text { Mainte- } \\
\text { nance. }\end{array}$ & $\begin{array}{l}\text { General ex- } \\
\text { pense. }\end{array}$ & Total. & $\begin{array}{l}\text { Months } \\
\text { carried. }\end{array}$ \\
\hline \multirow{4}{*}{$\begin{array}{l}\text { June } \\
\text { July } \\
\text { Aug. } \\
\text { Sept. }\end{array}$} & 1. & $\$ 5,000$ & & & & & \multirow{11}{*}{$\begin{array}{r}\$ 5,000.00 \\
1,107.50 \\
11,444.27 \\
8,625.79 \\
5,000.00 \\
8,188.29 \\
19,125.79 \\
7,125.79 \\
5,000.00 \\
8,375.11 \\
8,312.61 \\
13,312.61 \\
4,075.84 \\
545.00 \\
545.00\end{array}$} & \multirow{12}{*}{$\begin{array}{l}14 \\
13 \frac{1}{2} \\
12 \frac{1}{2} \\
11 \frac{1}{2} \\
11 \\
10 \frac{1}{2} \\
9 \frac{1}{2} \\
8 \frac{1}{2} \\
8 \\
71 \\
6 \frac{1}{2} \\
5 \frac{1}{2} \\
4 \frac{1}{2} \\
3 \frac{1}{2} \\
2 \frac{1}{2}\end{array}$} \\
\hline & & 5,000 & $\$ 4,299.27$ & $\$ 1.500$ & $\begin{array}{r}\$ 500 \\
100\end{array}$ & $\$ 607.50$ & & \\
\hline & & $\therefore \ldots$ & $5,755.79$ & 1,500 & 825 & 545.00 & & \\
\hline & 15. & 5,000 & 5.755 .79 & 1.500 & 325 & 607.50 & & \\
\hline ct. & 15. & 5,000 & $5,755.79$ & 7,500 & 325 & 545.00 & & \\
\hline $\begin{array}{l}\text { Nov. } \\
\text { Dec. }\end{array}$ & 5. & $\ddot{5,000}$ & $5,755.79$ & & & 545.00 & & \\
\hline & 15. & & $7,542.61$ & & 225 & 607.50 & & \\
\hline $\begin{array}{l}\text { Feb. } \\
\text { Feb. }\end{array}$ & & $\ddot{0} 000$ & $7,542.61$ & 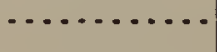 & $\begin{array}{l}225 \\
225\end{array}$ & 545.00 & & \\
\hline Mar. & 15. & ....... & $3,243.34$ & & 225 & $\begin{array}{l}540.00 \\
607.50\end{array}$ & & \\
\hline Apr. & 15 . & & -5 & & & 545.00 & & \\
\hline \multirow{2}{*}{ May } & & & & & & 545.00 & & \\
\hline & Total. & 30,000 & $53,193.60$ & 12,000 & 3,800 & $6,790.00$ & $105,783.60$ & \\
\hline
\end{tabular}

The labor bills paid on July 15 cover felling, bucking, hewing, etc., and brush disposal and cutting defective trees for one month's cut of each product; that is, for oneeighth of the annual cut. The wages paid in August, September, October, and November cover the same items together with labor charges for one month's skidding. In the payments for December, January, and February, labor charges for hauling are included. The March payroll covers only the last month's hauling and skidding. 
The cost of horse feed averages $\$ 1,500$ per month for the eight months while skidding and hauling are in progress. It is necessary, however, to tote in the winter's supply in September; hence feed for five months is charged to the October expenditures. The expenditures for loose feed are included in the skidding and lumbering costs given on page 66 .

The payments for maintenance cover the salaries of a blacksmith at $\$ 75$ per month, two assistant blacksmiths at $\$ 50$ per month, and a harness maker at $\$ 50$ per month. These men are employed for eight months, July 15 to March 15. Material for the blacksmith and harness shops costing $\$ 1,000$ are also included in the payments for maintenance, one-half on August 15 and one-half on November 15; together with an expenditure of $\$ 1,000$ for keeping the flume in repair. Five hundred dollars of the latter item are paid on June 15, the rest in installments of $\$ 100$ during each of the succeeding five months.

Under "general expense" entries are charged the salaries of a foreman at $\$ 200$ per month, a bookkeeper at the headquarters camp at $\$ 100$, and a general agent and bookkeeper at the railroad yards at $\$ 125$. These are year-round men paid off on the 15 th of each month. Other items charged to general expense are the premium on a $\$ 20,000$ bond, amounting to $\$ 250$ annually paid in quarterly installments, beginning June 15; rent for the office at the yards, at $\$ 20$ per month; and $\$ 100$ per month to cover miscellaneous items such as selling lumber and props, check scaling, etc.

By multiplying the expenditure in each month by the number of months until date of delivery and dividing the sum of these products by 12 , the average working capital required for logging op rations is found to be $\$ 80,176.53$.

Expenditures for milling, fluming, and driving are incurred during the five mon ths' season from May 15 to October 15; and average as of August 1, the average date of delivering the year's cut at the yards. On August 1, therefor, it can be fairly assumed that all milling, fluming, and driving charges have been paid, in addition to the stumpage and logging costs enumerated above. That is, an amount of working capital equivalent to the total annual expenditure for stumpage and operating costs is on that date invested in the year's cut. This amount is readily obtained for each product from the operating costs given on page 66 and the stumpage prices on page 67 as follows:

For hewn ties.......................... $\$ 44,997.12$

For sawed ties........................... 92, 897.28

For props............................... $30,816.00$

For lumber............................... 310.16

Both kinds of railroad ties will be sold and paid for within an average of one month after delivery. It is not probable that payment for props and lumber, however, will be received in less than an average of three months. A yearly fund of working capital equivalent to one-twelfth of the total cost of the railroad ties and one-fourth that of the other products is therefore needed to carry yard stock from date of delivery to date of sale. This amount is $\$ 21,772.74$ which, added to the working capital used in logging, makes the total for the operation, $\$ 101,949.77$. 


\section{APPENDIX.}

\section{FORM FOR SUMMARIZING THE ESSENTIAL DATA IN STUMPAGE APPRAISALS.}

The use of the following summary in outline form is desirable to present concisely the more essential features of the appraisal. This summary should be prefixed to all reports submitted to the Forester:

1. The sale area.

(1) District, Forest, main watershed or other descriptive location, designation of sale or chance.

(2) Area covered by appraisal (acres).

(3) Distance from chance to common carrier, or local market, by proposed logging road, flume, drivable stream, etc. (method of transportation and miles).

(4) The stand:

a. Total estimated cut (thousand feet).

$b$. Name and per cent of each species.

c. Kind and per cent of each product to be cut (saw logs, ties, mine props, etc.).

2. Investments.

(1) Name main units (railroad or flume with length, sawmill with capacity, etc.).

.(2) Average fixed investment. (Profit-bearing.)

(3) Annual depreciation.

(4) Average working capital.

(5) Total average investment in operation.

3. Cost of production (per thousand feet log scale, piece or other unit; separately by species or products as required).

(1) Depreciation.

(2) Logging.

(3) Manufacture.

4) General Expense.

(5) Forest Service requirements.

(6) Total.

1. Profit margin.

(1) Estimate of risk (low, average, high).

(2) Method used (investment, overturn, pay for personal services).

(3) Rate.

4 Profit in dollars and cents (per thousand feet log scale or other unit of output).

5. Selling price (per thousand feet log scale, piece, or other unit; separately by species and products as required).

6. Recommended stumpage price (per thousand feet log scale, piece, or other unit; separately by species and products as required).

7. Important contract terms.

(1) Cutting period.

(2) Construction period.

(3) Other terms which materially influence the appraisal.

70 



